\title{
Assistência ao paciente em fase terminal: alternativas para o doente com aids.
}

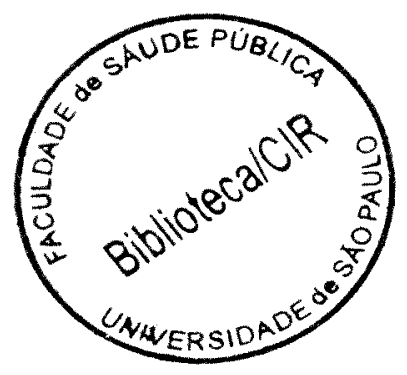

Maria Aparecida Telles Guerra

Tese de Doutorado apresentada ao Departamento de Práticas de Saúde da Faculdade de Saúde Pública da Universidade de São Paulo para obtenção do Grau de Doutor.

Área de concentração: Administração Hospitalar.

Orientador: Prof. Dr. Marcos Kisil

São Paulo 
A minha mãe e meus irmãos,

à tia Elza e à tia Geny,

todos eles mestres na arte de cuidar. 


\section{Agradecimentos}

Ao Marcos, que me deu liberdade para ousar em uma área tão nova, respeitando meu longo processo exploratório e assegurando orientação precisa nos momentos críticos;

aos chefes e colegas do Instituto de Infectologia Emílio Ribas, que me permitiram o necessário afastamento das rotinas do serviço, apoiando a realização deste trabalho;

aos colegas da Equipe de Cuidados Paliativos, pela dedicação com a qual realizam seu trabalho, afirmando concretamente a sua importância e factibilidade;

ao Dr. Marco Túlio, pelo exemplo e apoio;

aos profissionais, pacientes e familiares do Hospice Atlanta e do Haven House Hospice ( Atlanta, GA USA) e sobretudo do Zen Hospice Project ( San Francisco, CA USA ) que me ensinaram com carinho as lides dos cuidados ao final da vida;

aos profissionais do Serviço de Arquivo Médico, Coleta e Classificação de Dados e da Biblioteca do I.I.E.R., pela preciosa colaboração;

a todos os entrevistados, que gentilmente me cederam seu tempo, e compartilharam comigo seus pensamentos a respeito dessa nova temática;

aos amigos imprescindíveis, a quem confiei minhas dúvidas e certezas, e que me deram apoio e sugestões;

a meus familiares, que sempre me deram forças para prosseguir estudando, mesmo que às custas de ausências e omissões;

a todos o meu sincero: muito obrigada !

Ah, não se pode esquecer: graças a Santo Expedito por concluir em tempo ! 


\section{Resumo}

Guerra MAT. Assistência ao paciente em fase terminal: alternativas para o doente com aids. São Paulo; 2000. [ Tese de Doutorado - Faculdade de Saúde Pública da Universidade de São Paulo ].

As alternativas de assistência a pacientes em fase terminal foram estudadas através de revisão bibliográfica sobre o tema, com particular ênfase no conceito hospice de assistência, que visa atender o paciente integralmente, em suas necessidades fisicas, mentais, sociais e espirituais. Buscou-se também verificar a emergência - no sentido de constatação e acolhimento - da necessidade de se prestar uma assistência melhor qualificada a doentes com aids em fase terminal, no Brasil, tomando-se como caso o Instituto de Infectologia Emílio Ribas da Secretaria de Estado da Saúde de São Paulo, centro de referência nacional para o tratamento e ensino de aids e doenças infecciosas em geral. Concluiu-se que novas práticas assistenciais vêm surgindo nessa instituição, dirigidas a pacientes adultos com aids em fase terminal, como as realizadas por uma equipe multiprofissional que presta cuidados paliativos. Os profissionais pesquisados percebem a necessidade de melhora dessa assistência, tendo contribuido com várias sugestões para minorar o sofrimento dos pacientes. Ao mesmo tempo, notou-se que as propostas de incorporação de cuidados paliativos no atendimento a pacientes com aids em fase terminal também vêm sendo aceitas pela administração do hospital e que estão sendo promovidas pelos responsáveis pelas diretrizes programáticas nacionais de controle da aids. 


\section{Summary}

Guerra MAT. Assistência ao paciente em fase terminal: alternativas para o doente com aids. [ End-of-life care : alternatives for the aids patient. ] São Paulo ( BR ); 2000. [ Tese de Doutorado - Faculdade de Saúde Pública da Universidade de São Paulo ].

End-of life care alternatives were studied through literature review, particularly focusing on hospice concept, that treats the patient through an integrative perspective, considering its physical, mental, social and spiritual needs. The need for a better care for the dying aids patients in Brazil were investigated by studying the case of the Instituto de Infectologia Emilio Ribas, in São Paulo, Brazil, a national reference center for aids and infectious diseases' treating and teaching. The results show that new health practices are emerging in this institution, targeted to adult patients at aids final stage, as those performed by a multiprofessional palliative care team. The health workers interviewed noticed a need for a better assistance for these patients, contributing with many suggestions. At the same time, it was noticed an approval to this new practices from the hospital administration, and a movement from the national aids program coordination to promote it. 


\section{Índice}

I - Introdução . . . . . . . . . . . . . . . . . . . . . . . . . . 1

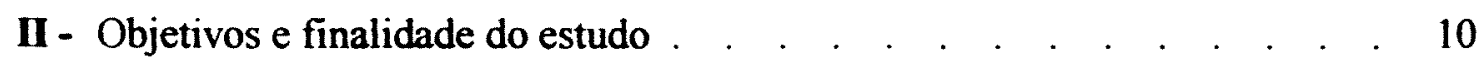

III - Procedimentos metodológicos . . . . . . . . . . . . . . . . . . . . . . . . 11

III - 1 Estudo bibliográfico . . . . . . . . . . . . . . . . . . . . 11

III - 2 Estudo de caso . . . . . . . . . . . . . . . . . . . . . . . . 12

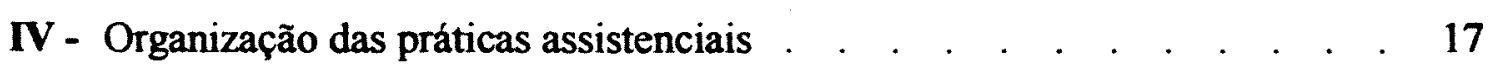

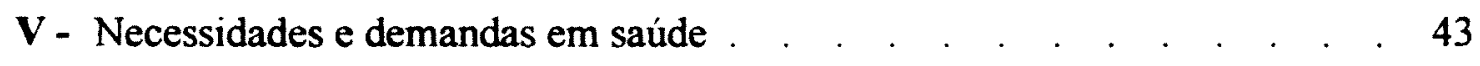

VI - Qualidade das práticas . . . . . . . . . . . . . . . . . . . . . 55

VII - Assistência aos doentes em fase terminal: breve histórico . . . . . . 60

VIII - Aids: aspectos clínicos e epidemiológicos; assistência aos doentes . . . . $\quad 87$

IX - Caso: o doente com aids em fase terminal, no I.I.E.R. . . . . . . . . . 97

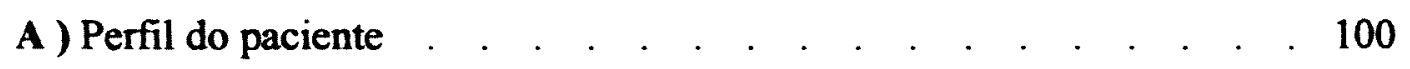

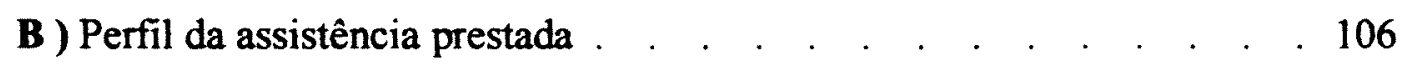

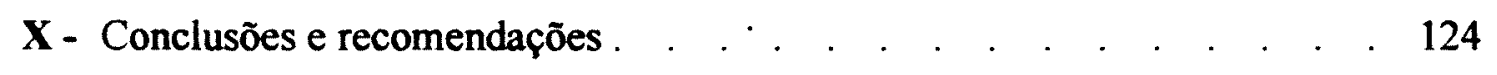

Referências bibliográficas . . . . . . . . . . . . . . . . . . . 137

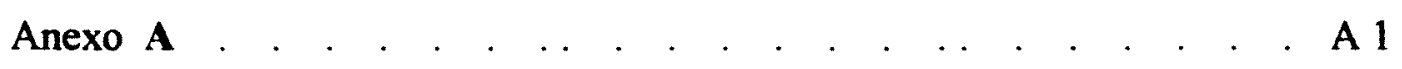

Anexo B . . . . . . . . . . . . . . . . . . . . . . . . . . A 2

Anexo C . . . . . . . . . . . . . . . . . . . . . . A 3 


\section{I - Introdução}

"When it is not possible to save a life, I have learned and
have begun to teach how to 'save a death', as I have come
to call it - to help a patient preserve comfort and dignity
despite overwhelming illness and to help a family
understand the inevitability of the death, how the death
might at this time be appropriate, and how to move forward
in the process of bereavement. Saving deaths, I have come
to realize, is as important and rewarding as saving lives. "
medica U.T.I.,
Mount Sinai School of Medicine, New York

( Nelson JE 1999, p. 777 )

Aliviar o sofrimento dos doentes é função do médico, tanto quanto prevenir e tratar suas enfermidades. Em tempos remotos, quando o homem detinha quase nenhum controle sobre a ocorrência e evolução das doenças, a Medicina se constituía como campo de conhecimento e de práticas destinadas à obtenção da melhora do estado geral e do conforto dos pacientes. A Medicina de hoje, ao contrário, se ocupa muito mais com questões relacionadas à cura, tanto no âmbito de sua prática quanto nos âmbitos da pesquisa e da educação médicas ( Cassel 1982 ). No entanto, tratar adequadamente um doente nem sempre significa que suas doenças sejam curadas, ou mesmo controladas, como ocorre freqüentemente com doentes sem possibilidades de cura.

Muitos doentes que não se beneficiam dos tratamentos curativos indicados ao controle de suas doenças podem receber considerável conforto e melhora de seu estado geral com a instituição do tratamento paliativo, de preferência de caráter integral. Isto é, de tratamento dirigido ao alívio do sofrimento em todas as suas dimensões: física, psíquica, social, espiritual.

\footnotetext{
1 "Quando não é possivel salvar uma vida, eu aprendi e tenho começado a ensinar o que eu chamo de 'salvar uma morte': - a ajudar o paciente a preservar conforto e dignidade apesar da doença esmagadora, a ajudar a familia a compreender a inevitabilidade da morte e como a seu tempo ela pode ser apropriada, e como se encaminhar no processo de luto. Salvar mortes, eu passei a entender, é tão importante e gratificante como salvar vidas."
} 
A assistência aos pacientes sem possibilidades de cura vem atraindo a atenção de profissionais e da população usuária de serviços de saúde em paises desenvolvidos, desde há algumas décadas. $O$ trabalho pioneiro de Dame Cicely Saunders, na Inglaterra, levou à criação de uma instituição modelo na prática, ensino e pesquisa do atendimento a doentes em fase terminal em 1967 ( o St. Christopher's Hospice, em Londres ). A sua preocupação com o sofrimento desses doentes, à época em que trabalhava como enfermeira em hospitais para doentes de câncer, levou-a a graduar-se em Medicina e a dedicar-se à remodelação da assistência médica a esses pacientes. Muito do que se conhece hoje sobre cuidados paliativos e controle de dor iniciou-se nesse periodo. Pouco tempo depois surgia nos Estados Unidos da América o Movimento Hospice, visando aliviar o sofrimento de doentes que morriam em hospitais, longe de seus familiares; sofrimento este muitas vezes devido ao próprio tratamento instituído. Declarando-se contra os procedimentos médicos agressivos e dolorosos que apenas prolongam a agonia dos doentes sem lhes trazer benefícios significativos, esse movimento propôs a assistência aos agonizantes em suas casas ou ambientes similares, dando apoio logístico e suporte emocional aos pacientes e seus familiares, durante todo o processo de morrer. Essa forma alternativa de assistência aos doentes em fase final, assumida inicialmente por leigos em trabalho voluntário, encontrou aceitação ampla da sociedade, nesse país. Logo o chamado conceito hospice de assistência a doentes em fase terminal foi implementado e incorporado ao sistema de saúde dominante nos Estados Unidos da América, onde encontra-se hoje bem integrado ( Wald 1996 ). Outros países desenvolvidos, principalmente os europeus e países anglófonos de outros continentes, também desenvolveram esse modelo assistencial, a partir da década de setenta. A morte, tema até bem recentemente evitado nas sociedades ocidentais modernas, passou a ser novamente encarada nesses países, ao se discutir e reorganizar a assistência médica ao morrer.

O resgate da concepção da naturalidade da morte - vigente no início do século - passou a ser defendido por especialistas em Ética Médica, e a medicalização do processo de morrer denunciada como nociva ao doente, aos familiares, ao sistema de saúde, e à sociedade. A literatura médica das últimas décadas tem apresentado grande volume de publicações sobre o tema, debatendo 
questões éticas e técnicas, mostrando tanto sua complexidade como o interesse recentemente desperto por ele. A Bioética, campo de conhecimento conformado recentemente, vem se ocupando, entre outras, de muitas questões relacionadas `a assistência médica a doentes em fase final, como: prolongamento artificial da vida, eutanásia, distanásia, suicídio assistido, direito à informação médica, etc.. Novas especialidades médicas, como Cuidados Paliativos, Controle de Dor, evidenciam a importância que a assistência a doentes sem possibilidades de cura vem assumindo nos países desenvolvidos e, em menor escala, também aqui no Brasil.

Vale lembrar que também em nossa sociedade o processo de morrer tem ocorrido massivamente dentro de hospitais, principalmente nas grandes cidades. $O$ aumento da prevalência de câncer e outras doenças crônico-degenerativas ( Monteiro 1997 ) verificado no Brasil nos últimos anos tem aumentado a ocorrência de doentes em fase terminal às portas dos hospitais, em busca de assistência. As dificuldades desses pacientes para obter tratamento adequado são sobejamente conhecidas de todos: profissionais de saúde, usuários e sociedade geral. Devido ao despreparo dos serviços para esse atendimento, a qualidade da assistência prestada aos doentes sem chances de cura é, quase sempre, bastante deficiente. Invariavelmente ocupados com o tratamento dos demais pacientes, a maioria dos profissionais de saúde parece não ter olhos para aqueles que se encontram vivendo sua fase final. Sem possibilidades, ou com poucas chances de cura, porém com grande necessidade de tratamento fisico, mental, social, espiritual - esses pacientes sofrem indevidamente, por terem suas necessidades desconsideradas por parte das políticas públicas de saúde, das instituições médicas, e das escolas formadoras de pessoal da saúde.

A existência de enormes carências de saúde ainda não equacionadas, aqui no Brasil, pode ser um dos fatores que impedem a consideração das necessidades dos doentes em fase terminal, em todos os níveis da assistência à saúde, ao lado de tantos outros fatores, como: questões culturais, mecanismos de mercado, rigidez estrutural das instituições. No entanto, a resposta a necessidades dessa parcela de doentes não precisa significar, obrigatoriamente, menos recursos para o atendimento a outras demandas. Ao contrário, a alocação racional de recursos pode e deve otimizar a sua disponibilidade. 
A legitimação e acolhimento das carências e necessidades dos doentes em fase terminal tem sido, aqui no Brasil, um processo lento, ainda incipiente. Por se tratar de um tema - tanto a morte como o morrer - evitado ${ }^{2}$ pela sociedade, existe um grande obstáculo cultural a dificultar a discussão da assistência a esses doentes. $E$, diferentemente do que ocorre com portadores de outros agravos crônicos que se unem para lutar por atendimento adequado, esses pacientes não podem se organizar para demandar melhor assistência: sua voz é, quase sempre, pouco articulada, tímida; sobretudo pouco duradoura. Os profissionais de saúde, por sua vez, em sua imensa maioria carecem de formação adequada para a atuação nessa área, contando com parcos recursos técnicos e emocionais para assistir à agonia dos pacientes nos hospitais. Isto porque, ao contrário do que muitos leigos supõem, as escolas de graduação em Medicina, Psicologia, Enfermagem, etc., não estão preparando seus alunos para essa atuação ( Sayd 1993, Rabow et al. 2000, Kovács 1992, Boemer et al. 1991), ainda que desde há algumas décadas as mortes da população das grandes cidades venham ocorrendo maioritariamente dentro dos hospitais

A capacitação dos profissionais de saúde para a adequada assistência aos pacientes sem possibilidades de cura requer mudanças de valores e de atitude frente à morte e ao processo de morrer, e não a simples aquisição de conhecimentos técnicos e de habilitação prática para a realização de procedimentos. Este aprendizado é melhor promovido quando ocorre juntamente à formação profissional - e não requer mudanças de hábitos já instalados - daí a importância do engajamento das instituições de ensino, quer se trate de profissionais de nível universitário ou de auxiliares. Em uma área do conhecimento em que quase não se dispõe de professores e serviços qualificados - a especialização nesse tema é bastante recente, mesmo em países desenvolvidos - as inovações necessárias vêm ocorrendo lentamente aqui no Brasil, movidas por profissionais fortemente motivados, que buscaram ativamente sua especialização na assistência aos doentes em fase terminal, capacitando-se no exterior e/ou adquirindo experiência e refletindo sobre ela de modo autodidata.

2 A esse respeito Becker analisa a negação inconsciente da morte ( Becker 1995 ), Kübler-Ross referese à morte encarada com um tabu ( Kübler-Ross 1998 p. 10 ), Ariès ( fundamentando-se nos trabalhos de Gorer ) e Martins, no Brasil, falam da morte interditada, nas sociedades ocidentais modernas ( Ariès 1990 p. $612-656$, Martins 1983 p. 9 ). 
Como é de se supor, os profissionais que têm se mostrado sensiveis a essa questão são, o mais das vezes, aqueles que em seu dia-a-dia se envolvem mais no atendimento a pacientes portadores de doenças crônicas nem sempre curáveis, que habitualmente levam à morte. Tanto nos países desenvolvidos como aqui no Brasil, o câncer, em suas múltiplas manifestações, é a doença mais prevalente entre os doentes considerados em fase terminal, qualquer seja o critério utilizado na definição de terminalidade ( Fordham et al. 1998, Higginson 1998, Cassorla 1991 ). Outras doenças crônicas de difícil controle ( doença pulmonar obstrutiva, algumas insuficiências cardíacas, cirrose hepática, doenças neurológicas de evolução progressiva ), também levam os doentes a uma fase terminal - como, aliás, também a pura senescência mas a incerteza dos prognósticos muitas vezes dificulta a determinação de uma provável duração da sobrevida. A incerteza prognóstica ou, em outras palavras, a imprevisibilidade da evolução do processo de morte, em muitos casos favorece a manutenção da esperança de cura, como também a negação da morte, mesmo quando existe possibilidade concreta de identificação da fase terminal.

O prognóstico de morte próxima é quase sempre assustador, tanto para os pacientes e seus familiares e entes queridos, como também para os profissionais que os tratam. A inevitabilidade da morte costuma ser, no mínimo, desagradável e indesejada. Geralmente a fase terminal se anuncia quando, na vigência de doença progressiva e incurável em fase avançada, não existem possibilidades razoáveis de resposta ao tratamento específico ( Sancho 2000 ). Os sintomas da doença podem escapar ao controle médico, comprometendo consideravelmente a qualidade de vida do paciente e encontram-se evidências clínicas de que a morte é certa e não muito distante. Essa fase pode ter uma duração bastante variável, de poucos dias a alguns anos. Nos Estados Unidos da América considera-se o doente em fase terminal quando o seu prognóstico de sobrevida não ultrapassa 6 meses; esse prognóstico é critério de elegibilidade necessário para o atendimento em serviços hospice, critério “administrativo", do sistema financiador dos serviços de saúde ( Rhymes 1990 ).

A interrupção do tratamento curativo costuma ser considerada quando os efeitos colaterais do tratamento instituído passam a ser mais danosos que benéficos, impondo grande sofrimento ao paciente. Mesmo nessa situação, muitos doentes 
superestimam suas possibilidades de sobrevivência e procuram tratamentos baseados em falsas estimativas de riscos e beneficios ( Weeks et al. 1998 ). Muitos médicos também, mesmo cercados de fortes evidências clínicas, não conseguem aceitar com serenidade o prognóstico de morte: encaram-na como falha médica e realizam todos os procedimentos possíveis para prolongar a vida do paciente, a qualquer custo. Esta prática tem sido chamada, na literatura médica, de obstinação terapêutica ( Abiven 1999 ) e o tratamento realizado nessas condições referido como fútil ( Youngner 1995 ).

As doenças que seguem curso irregular, com longos períodos de bom estado geral devidos a uma real ou aparente remissão da doença, interrompidos por surtos de agudização ou por intercorrências, são de mais difícil prognóstico que as demais doenças crônicas. É o caso da aids que, ademais, tem tido seu curso natural modificado inúmeras vezes, desde que a epidemia surgiu, pela descoberta e introdução de novas drogas em seus esquemas terapêuticos. De fato, o trabalho cotidiano na assistência aos doentes com aids tem proporcionado aos profissionais nele envolvidos a possibilidade de testemunhar as grandes mudanças ocorridas no desenrolar dessa pandemia. Assim, de "peste gay" fulminante, do início de sua história, a doença geral controlável pelo uso de medicamentos, essa síndrome tem trazido diferentes expectativas a seus portadores e tratadores, ao longo do tempo.

Embora já tenha causado a morte de milhões de pessoas - em sua imensa maioria adultos jovens - em todo o mundo, e de milhares no Brasil ${ }^{3}$, a aids vinha deixando de ser encarada como uma doença ameaçadora da vida nos últimos anos, após a introdução das novas terapias, mais potentes, no arsenal terapêutico. No entanto, essa síndrome cada vez mais crônica e tratável, continua uma doença fatal. As poderosas drogas atualmente utilizadas com sucesso no controle da aids nem sempre funcionam adequadamente: param de fazer efeito após um certo período de uso, ou não são toleradas pelos pacientes devido a seus efeitos colaterais, ou o nível mínimo de aderência aos esquemas terapêuticos preconizados são incompativeis com o estilo de vida de muitos pacientes, por razões de ordem social, econômica ou comportamental ( Selwyn e Amold 1998 ). Ainda, o diagnóstico tardio da doença faz

\footnotetext{
3 Segundo dados da Organização Mundial de Saúde, ocorreram 2,6 milhões de mortes por aids em todo o mundo, apenas no ano de 1999 ( WHO 1999). No Brasil, o total de óbitos acumulados desde o início da epidemia até meados de 2000 atinge mais de 95000 ( MS 1999/2000).
} 
com que muitos doentes cheguem aos serviços de saúde já sem possibilidades de cura. Enquanto não se conta com a cura dessa síndrome, ela é considerada, ainda hoje, como mais uma doença crônica de difícil controle, levando muitos pacientes a uma fase terminal e à morte (Welch et al. 1998, Gomes 1998/1999).

A existência de pacientes com aids em fase terminal nas enfermarias do Instituto de Infectologia Emílio Ribas ( I.I.E.R. ) - instituição hospitalar pertencente à rede pública estadual e centro de referência nacional para o tratamento de doenças infecciosas - tem sido constante, desde o surgimento da epidemia no Brasil, no início dos anos 80 . Desde então, os profissionais que trabalham nesse hospital têm se desdobrado para fazer frente aos desafios trazidos por ela. No inicio, quando sequer se conhecia o agente etiológico da aids, o medo do contágio e o convívio com a morte fulminante de pacientes jovens constituiam as sobrecargas de trabalho mais ameaçadoras. A seguir, a perplexidade com o perfil dos novos usuários dos leitos hospitalares: não mais crianças com infecções agudas de alta taxa de cura, mas adultos pertencentes a grupos socialmente estigmatizados: homossexuais, travestis, usuários de drogas. Aprender a lidar com as peculiaridades da nova clientela, assimilá-las atenuando seu estigma, assumir novos valores e atitudes frente à diversidade das pessoas foram novas tarefas que esses profissionais tiveram que realizar ( Camargo 1994 ). Ao lado disso, como não poderia deixar de ser, capacitar-se tecnicamente para tratar dos doentes, assegurando-lhes o melhor arsenal diagnóstico e terapêutico disponivel. Lidar com a morte constante de pacientes jovens, no entanto, era e permanece até hoje uma tarefa difícil de encarar (Guerra et al. 1992 ).

A emergência da aids no cotidiano dessa instituição sem dúvida foi um dos fatores responsáveis pela experimentação de modelos alternativos de funcionamento dos serviços, a partir do final dos anos 80 . Exemplo disso é o surgimento do Projeto de Atendimento Comunitário, realizado por uma equipe multiprofissional que se desloca do hospital para prestar assistência nas Casas de Apoio onde os pacientes residem. O seu hospital-dia, hoje serviço modelo e centro de treinamento nacional nessa modalidade de atendimento, também surgiu como uma proposta inovadora nesse Instituto. Responsável pelo tratamento de algumas intercorrências comuns dos pacientes de aids, o hospital-dia evita muitas internações ( Casseb et al. 1999 ). 
A instituição de esquemas terapêuticos mais eficazes (o popular coquetel ) que revolucionou o tratamento e as expectativas de vida dos pacientes no final de 1996, fez diminuir o número e tempo médio das internações no I.I.E.R., bem como a morbidade por doenças oportunistas tratadas no hospital-dia, nos anos subseqũentes. Principalmente: fez cair sensivelmente a mortalidade pela aids (Casseb et al. 1999 ). A eficácia dos novos esquemas terapêuticos trouxe, sem dúvidas, modificações ao cotidiano hospitalar. Os médicos da instituição trataram de se capacitar no manejo das novas drogas - com numerosas contra indicações e efeitos colaterais - e na interpretação dos exames laboratoriais necessários ao monitoramento do tratamento. Os psicólogos e assistentes sociais prepararam-se para trabalhar com novas expectativas de vida, auxiliando os pacientes a resolverem problemas relacionados ao viver com uma doença crônica de evolução incerta. Uma tarefa difícil: manter a aderência a um tratamento complexo, por tempo longo e indeterminado, e um sério comprometimento do paciente para evitar, sempre, a transmissão da doença a outros.

Embora a letalidade da aids tenha diminuído significativamente no período 1996 - 1997 ( de 32 \% para $23 \%$ ) ( Casseb et al. 1999 ), o número de óbitos de pacientes atendidos no hospital ainda é alto em suas enfermarias: quase 1 óbito/dia. Assistir ao morrer dos pacientes é uma tarefa que, mesmo indesejada, compete aos profissionais de saúde, e estes precisam se capacitar - técnica e emocionalmente para realizá-la adequadamente.

Preparar-se para atender doentes adultos jovens morrendo, prestando-lhes a assistência mais adequada, vem se esboçando lentamente no I.I.E.R.. Algumas iniciativas para dar mais conforto ao paciente, como autorização de visitas fora do horário regular e o abrandamento das restrições alimentares, a exemplo do que já vem ocorrendo desde há muitos anos nas áreas de atendimento infantil, vêm ocorrendo esporadicamente em algumas de suas enfermarias. Cursos de capacitação de profissionais para lidar com a morte e o morrer dos doentes, realizados por outras instituições, têm sido divulgados em seus murais, nos últimos tempos. Com freqüência crescente pode-se encontrar nos corredores do hospital algum grupo de funcionários - de médicos a auxiliares - discutindo a conduta mais apropriada frente à inevitabilidade e provável proximidade da morte de algum de seus pacientes. 
Em Julho de 1999 constituiu-se um grupo multiprofissional para prestar atendimento de cuidados paliativos a pacientes internados nessa instituição. A equipe é formada por trabalhadores que voluntariamente se organizaram para atender pacientes com doença avançada ou que apresentem sintomas físicos de difícil controle, como dor. A Equipe de Cuidados Paliativos do I.I.E.R. presta atendimento especializado em regime de inter-consulta, quando solicitada. Embora a assistência ao doente continue sob a responsabilidade dos profissionais da enfermaria em que este se encontra, a equipe de cuidados paliativos se envolve com o atendimento direto ao doente em fase terminal, orientando ou realizando procedimentos como analgesia, sedação terminal, suporte psicológico para pacientes e familiares.

As condições atuais de assistência aos pacientes sem possibilidades de cura no I.I.E.R. ainda podem ser bastante melhoradas, tanto quando se as analisa a partir das possibilidades concretas de atendimento, algumas já experimentadas em outras sociedades, como quando analisadas através dos discursos e da mobilização de seus profissionais, em busca de melhor qualidade desse atendimento. Novas práticas assistenciais têm se viabilizado nessa instituição, nos últimos anos, com a mudança do perfil epidemiológico de sua clientela, como já referido, devido à mobilização de seus profissionais. Há indícios de que um novo modelo de assistência ao doente em fase terminal esteja surgindo nesse Centro de Referência Nacional para o tratamento de pacientes de aids, em resposta à percepção de uma necessidade que começa a ser legitimada.

O propósito deste estudo é identificar alternativas de assistência ao paciente com aids em fase terminal, nessa instituição, verificando tanto a constatação e acolhimento da necessidade de se prestar uma assistência melhor qualificada a esses doentes, por parte dos profissionais envolvidos, como também verificar o surgimento de novas práticas e propostas de atendimento, que possam contribuir para a diminuição do sofrimento dos pacientes tidos como sem possibilidades de cura. 


\section{II - Objetivos e finalidade do estudo}

\section{Objetivo geral:}

Identificar a emergência de novas práticas e indicações de mudança no modelo de assistência aos doentes com aids em fase terminal.

\section{Objetivos específicos:}

Estudar uma nova forma de assistência ao doente em fase terminal, o conceito Hospice de cuidados, vigente em países desenvolvidos ocidentais, principalmente Inglaterra e Estados Unidos da América e a emergência dos cuidados paliativos como campo de práticas multiprofissionais em saúde.

Estudar a assistência prestada aos pacientes adultos com aids em fase terminal internados no Instituto de Infectologia Emílio Ribas, hospital público estadual de São Paulo, responsável pelo atendimento de parte significativa dessa clientela e referência nacional de tratamento e ensino de doenças infecciosas, e a avaliação sobre ela, feita pelos profissionais que a realizam.

\section{Finalidade do estudo:}

Trazer subsídios para a melhor adequação da assistência prestada aos doentes de aids adultos em fase terminal, nos hospitais públicos brasileiros. 


\section{III - Procedimentos metodológicos}

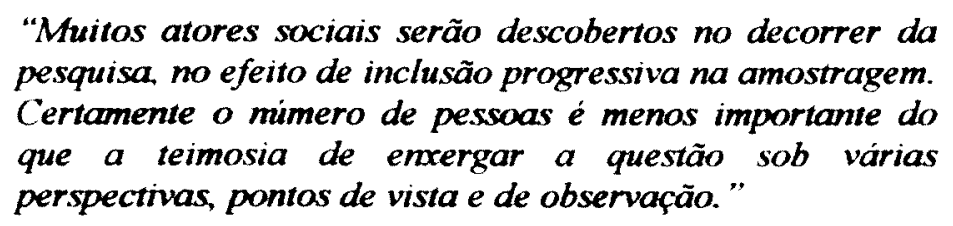

( Minayo 1994, p. 103 )

Trata-se de um estudo teórico-prático sobre a temática abordada, constando de uma revisão bibliográfica dos temas-chaves e de um estudo de caso de tipo exploratório, com abordagens quantitativa e qualitativa, realizados ao longo de um período de aproximadamente dois anos, de Junho de 1998 a meados de 2000.

\section{III . 1 - Estudo bibliográfico}

A análise de alternativas para a assistência aos doentes com aids em fase terminal envolve a compreensão prévia de alguns temas-chaves, os quais foram alvo de revisão bibliográfica sistemática. São eles:

$\Rightarrow$ Organização das práticas assistenciais.

$\Rightarrow$ Necessidades e demandas em saúde.

$\Rightarrow$ Qualidade das práticas de saúde.

$\Rightarrow$ Assistência aos doentes em fase terminal : breve histórico.

$\Rightarrow$ Aids: aspectos clínicos e epidemiológicos.

A revisão bibliográfica realizada não pretendeu ser exaustiva, mas sim, favorecer a compreensão da temática estudada, através da contribuição de alguns textos clássicos e de artigos publicados mais recentemente na literatura especializada de cada uma das áreas abordadas. 


\section{III .2 - Estudo de caso}

\section{A - Perfil dos pacientes:}

Optou-se por realizar a pesquisa junto aos pacientes atendidos em regime de internação hospitalar, por ser este o modelo hegemônico de assistência prestada aos doentes com aids em fase terminal. Assumiu-se como fase terminal, para efeitos deste estudo - e apenas como conceito operacional - o periodo da internação hospitalar que culminou com a morte do paciente, de qualquer duração.

O trabalho de campo - estudo do tipo retrospectivo, com pesquisa em fontes secundárias - foi realizado a partir de Julho de 1999, com a coleta de dados dos prontuários médicos e, de modo suplementar, das fichas de notificação de aids ao Sistema de Vigilância Epidemiológica. Todos os dados foram coletados por um único pesquisador, mantendo-se a homogeneidade do trabalho.

Os dados necessários à caracterização demográfica e epidemiológica dos pacientes e à verificação do seu perfil de morbidade e de utilização de serviços foram registradas em um formulário comum, para esse fim desenhado, que foi submetido a um teste preliminar para aprimorar sua operacionalidade. (Anexo A)

Um inquérito prévio junto ao Serviço de Arquivo Médico e Coleta e Classificação de Dados e Estatísticas do I.I.E.R. ( S.A.M.C.C.D. ) demonstrou a não existência de influência sazonal no movimento de pacientes com HIV/aids quanto ao número de internações, perfil de morbidade e mortalidade geral. Isto posto, optou-se por estudar um conjunto amostral constituído por um corte transversal representativo da clientela com aids, adulta, que tivesse morrido na instituição estudada. $O$ mês de Junho de 1999 foi definido aleatoriamente como o período da amostra.

Os números totais de internações e de óbitos de pacientes do hospital foram consultados pela pesquisadora nos boletins de ocorrências mensais do S.A.M.C.C.D., onde eles rotineiramente são registrados, para a avaliação da magnitude do subgrupo populacional em foco. Para o estudo da representatividade da população atendida pelo I.I.E.R. junto ao município, pesquisaram-se os registros de mortalidade do Programa de Aprimoramento de Informações sobre Mortalidade, do Município de São Paulo ( Pro-AIM ), do periodo 1991 - 2000. 
A investigação do perfil epidemiológico dos pacientes e de aspectos referentes às internações hospitalares foi realizada utilizando-se os registros dos prontuários médicos dos pacientes estudados $\mathrm{e}$, suplementarmente, através da consulta a fichas de notificação epidemiológica de aids, como já referido. Isto é, trabalhou-se exclusivamente com fonte secundária de dados nessa fase da pesquisa. Todos os dados coletados foram registrados em formulário próprio, como já citado, e depois transferidos para um banco de dados computadorizado.

Os dados demográficos e epidemiológicos foram analisados através de métodos quantitativos: agrupados em categorias abrangentes e analisados segundo distribuição de frequências, para os dados categóricos, e segundo média, moda e mediana para os dados contínuos. Situações relevantes encontradas, tanto pela sua representatividade quanto pela sua singularidade, foram analisadas qualitativamente, e relatadas como caso modelo.

\section{B - Perfil da assistência prestada no I.I.E.R. \\ Perfil dos profissionais:}

Essa investigação foi desenvolvida junto aos profissionais envolvidos no atendimento direto aos pacientes. Em uma primeira etapa estes profissionais responderam a um questionário individual; na segunda fase do trabalho a temática da assistência ao doente terminal foi discutida em grupos constituídos pelas diferentes categorias profissionais envolvidas na pesquisa.

Elaborou-se um formulário para conter os dados necessários à caracterização profissional dos entrevistados e suas respostas às questões opinativas - avaliação do atendimento a pacientes em geral e a pacientes em fase terminal para ser utilizado no primeiro momento do estudo. ( Anexo B ) Esse instrumento foi submetido a um teste prévio, no mês anterior à realização das entrevistas válidas para a pesquisa, com profissionais do serviço de Ambulatórios do hospital, tendo-se mostrado adequado. Da mesma forma, criou-se um formulário para uso na segunda fase do trabalho, com questões abertas e fechadas, a serem respondidas após a discussão temática. ( Anexo $\mathrm{C}$ ). 
Os profissionais envolvidos na primeira fase da pesquisa pertencem a várias categorias, todas de nível universitário: assistentes sociais, enfermeiros, médicos e psicólogos, prestando assistência direta a pacientes internados no hospital, mesmo que também exercendo cargo de chefia. Pretendeu-se envolver a totalidade dos profissionais nessas condições, em exercício no momento da pesquisa. $O$ universo em cada categoria foi obtido junto às diretorias dos vários Serviços: de Enfermagem, Médico, de Saúde Mental, e Serviço Social.

O pesquisador apresentou o estudo e solicitou a colaboração de todos os profissionais, nas reuniões rotineiras de cada categoria. Os formulários foram distribuídos após o esclarecimento de eventuais dúvidas. Foram recolhidos cerca de duas a três semanas após sua distribuição. Os médicos foram, em sua maioria, entrevistados individualmente, após ampla divulgação de carta de apresentação da pesquisa. As entrevistas duraram 12 minutos, em média.

Os dados obtidos foram analisados através de métodos quantitativos: os dados referentes à caracterização dos profissionais foram analisados segundo distribuição de freqüências; as respostas sobre a qualidade do atendimento a pacientes, obtidas através de uma nota de valor entre 1 e 5 , foram analisadas através de média e desvio-padrão, moda e mediana.

Os profissionais envolvidos nas discussões temáticas da segunda fase da pesquisa são assistentes sociais, enfermeiros e psicólogos das unidades de internação do hospital, e os médicos responsáveis por esses serviços ( enfermarias ). O universo para cada categoria foi definido como o conjunto de todos os profissionais convocados para reunião junto ao respectivo serviço.

Nesta segunda fase solicitou-se uma reunião específica à chefia de cada categoria profissional envolvida, para apresentação e discussão da problemática referente à assistência aos pacientes em fase terminal. As reuniões seguiram a técnica de grupo focal ${ }^{4}$, para possibilitar a expressão de opiniões, atitudes e expectativas dos elementos do grupo, com a pesquisadora assumindo o papel de

\footnotetext{
${ }^{4}$ Segundo Westphal "o grupo focal é uma técnica de pesquisa que permite a obtenção de dados de natureza qualitativa a partir de sessões grupais em que 6 a 15 pessoas que compartilham um traço comum [...] discutem vários aspectos de um tema especifico (Westphal et al. 1996, p. 472 ).
} 
moderador da discussão. Após a apresentação do tema e de questões pertinentes, estimulou-se o debate de propostas de atuação no hospital e suas possíveis limitações. As questões levantadas e as observações foram anotadas pelo pesquisador. Os formulários foram distribuídos, para que os profissionais pudessem encaminhar outras sugestões posteriormente, como especial colaboração.

Nessa segunda fase, as questões fechadas referentes à caracterização dos profissionais foram analisadas segundo método quantitativo, ou seja: de distribuição de freqüências. Já as respostas às questð̃es abertas, referentes às opiniðes e sugestðes dos profissionais para a melhoria do atendimento ao paciente terminal no hospital, foram primeiramente agnupadas em categorias abrangentes segundo sua idéia central e depois analisadas também segundo sua freqüência. Algumas sugestðes ou falas dos profissionais foram transcritas literalmente e analisadas segundo seu conteúdo, pela sua representatividade ou singularidade dentre o conjunto de respostas obtidas.

\section{Perfil da administraçăo:}

Um outro conjunto de profissionais pesquisado é o daqueles ocupando posição ou exercendo função relevante para o estudo em questão, tanto do próprio Instituto de Infectologia Emilio Ribas, como de instâncias - administrativa ou programática - superiores. Estes profissionais foram entrevistados individualmente. As entrevistas com os dirigentes ou atores sociais especiais, do I.I.E.R. e da Secretaria de Estado da Saúde, seguiram um roteiro mínimo semi-estruturado, mas flexível, devido à singularidade do cargo ou posição ocupada. ${ }^{5}$ Todas as entrevistas foram realizadas e os dados coletados por um único pesquisador, mantendo-se a homogeneidade do trabalho.

Os diretores técnico e administrativo do Instituto de Infectologia Emílio Ribas, bem como o diretor técnico da Coordenação dos Institutos de Pesquisa instância da Secretaria de Estado de Saúde à qual o I.I.E.R. se encontra diretamente subordinado - foram identificados como atores de indiscutível relevância na tomada de decisðes, planejamento, e/ou gerenciamento desse serviço. Do mesmo modo, a

\footnotetext{
${ }^{5}$ As entrevistas buscaram resposta a pelo menos duas questðes comuns a esses atores estudados:

1 ) Quais as prioridades da instituiçăo para bem atender a sua clientela;

2 ) Como avalia a questão da assisstência ao paciente em fase terminal.
} 
responsável pela Unidade de Assistência da Coordenação Nacional de DST/Aids do Ministério da Saúde foi ouvida, pela importância desse órgão governamental na implementação de políticas e modelos assistenciais para portadores de HIV/aids.

As entrevistas com os dirigentes e detentores de cargos especiais do próprio Instituto e da Secretaria de Estado da Saúde foram solicitadas e obtidas pela própria pesquisadora, sem maiores dificuldades, após a apresentação dos seus objetivos. As entrevistas foram realizadas seguindo o roteiro básico pré definido, sem no entanto se ater apenas a ele, e tiveram duração variável, de 40 a 80 minutos. A responsável pela Unidade de Assistência da Coordenação Nacional de DST/Aids do Ministério da Saúde foi ouvida em sua apresentação no III Seminário Internacional de Cuidados Paliativos, realizado em São Paulo, em 13 de Abril de 2000.

As falas dos atores privilegiados, ou seja, dos detentores de cargos/posições especiais, foram submetidas a análise de discurso. $\mathrm{Na}$ análise tratou-se de buscar a "idéia central", que pode ser entendida como a síntese do conteúdo discursivo explicitado pelos sujeitos ( Simioni 1996 ). Segundo Minayo e Sanches, ao revelar situações, valores e intencionalidades, as falas podem indicar as transformações que ainda não tomaram forma, registrando as fases transitórias de um processo de mudança ( Minayo e Sanches 1993 p. 245).

\section{Perfil da instituição e da assistência prestada:}

O I.I.E.R. e seu papel na prestação de serviços a pacientes com aids foram estudados através de relatos orais de fatos de domínio público, de documentos oficiais internos e externos à instituição, boletins de divulgação de dados estatísticos e publicações científicas. Os relatórios elaborados pela Equipe Multiprofissional de Cuidados Paliativos do I.I.E.R. serviram de base para estudar a emergência de novas práticas no atendimento a doentes em fase terminal, desenvolvidas no I.I.E.R. essencialmente por essa equipe. Optou-se pela utilização desses relatórios tanto pela sua abrangência temática como pela representatividade multiprofissional.

A análise dos discursos de documentos contendo diretrizes, proposta de trabalho e relatório de atividades, do I.I.E.R. e outros, e também da sua Equipe Multiprofissional de Cuidados Paliativos, foi feita buscando-se sua idéia central. 


\title{
IV - Organização das práticas assistenciais
}

\begin{abstract}
"In the broadest terms, the medical role is in three areas: prevention of disease by personal and non-personal measures; care of the sick who provide scope, or more accurately, under existing services, while they provide scope, for investigation and treatment; and care of the sick who are not thought to require active intervention. Medical interest and resources are focused on the second area and, to a lesser extent, on personal prevention by immunization; the other responsibilities are relatively neglected. " 0
\end{abstract}

(McKeown 1976, p. 178 )

\section{Dinamismo e caráter histórico-social das práticas}

A assistência à saúde, mais do que proporcionar serviços médicos àqueles que adoecem, e procedimentos profiláticos como vacinas e orientaçðes à população geral, deve buscar condições de vida que favoreçam a manutenção e recuperação da saúde e a diminuição do sofrimento humano. Daí que seu campo de atuação extrapola aquele usualmente considerado o campo da saúde, como também o campo da prática médica, este ainda mais restritivo. A assistência à saúde tem necessariamente que tratar da política, da economia, da estrutura e dinâmica sociais, das condições ambientais, do contexto cultural e religioso da população em foco (Dever 1988, Evans e Stoddart 1990 ). Quando se objetiva a saúde, mais do que apenas diagnosticar e tratar as doenças, importa também eliminar os fatores de risco correspondentes e propiciar o bem estar - físico, psíquico, social e espiritual, como postula a Organização Mundial de Saúde - e a qualidade de vida.

\footnotetext{
6 “ Em termos gerais, o papel do médico está em tres áreas: prevenção de doenças através de medidas individuais e coletruas; cuidados aos doentes, nas questöes pertinentes, ou melhor dizendo, nas questöes abrangidas pelos serviços existentes, de imvestigação e tratamento; e cuidados aos doentes tidos como não requisitando intervenção ativa. Os recursos e o interesse médicos estão focalizados na segunda área e, em menor extensão, em prevenção individual por imumização; as outras responsabilidades são relativamente negligenciadas."
} 
Mas, mesmo nos paises desenvolvidos, a grande maioria dos recursos destinados à saúde é canalizada para a operacionalização de serviços de atendimento aos doentes e, em menor escala, para procedimentos preventivos específicos. Encontram-se, em todo o mundo, mais instituições dedicadas à assistência à doença que propriamente à prevenção de doenças e promoção da saúde ( Evans e Stoddart 1990).

A assistência médica individual é, hoje, "a forma hegemônica de se lidar com os problemas de saúde nas sociedades ocidentais cosmopolitas." ( Dalmaso 1998, p. 1 ). No entanto, ela tem menor importância - quando comparado com o papel de outros fatores como o ambiente, o fator biológico e o estilo de vida - na determinação do nível da saúde de uma dada população (McKeown 1976, Dever 1988 ).

A contribuição dos serviços de saúde e principalmente da assistência médica para a melhoria do nível de saúde, tanto individual como coletiva, foi alvo de produtivo questionamento nos anos 60 e 70, por parte de autores como McKeown, Illich, Szasz e outros, que a criticaram duramente ( McKeown 1976, Illich 1975, Szasz 1977 ). Ainda que persistam certas dificuldades metodológicas para medir o impacto dos serviços de saúde para a melhoria da saúde das populações, não há dúvida, hoje, que a assistência convencional à saúde contribui para esse fím, ainda que de modo menos importante do que postulado no passado (McKeown 1976, Evans e Stoddart 1990 ).

Além de proporcionar elevação do nível geral de saúde, a assistência à saúde centrada no atendimento aos doentes também traz, a grande parcela de pacientes assistidos, um conforto inegável. Conforto físico e psíquico, mesmo que na ausência de cura. Os casos em que o atendimento não traz melhora, ou até faz piorar a situação inicial - tanto devido a insuficiência técnica real como a uso equivocado da tecnologia disponível - não comprometem essa regra. No entanto, a assistência aos doentes, parcela mais visível da assistência à saúde, não está disponivel para todos, na imensa maioria dos países em desenvolvimento e até mesmo em alguns países desenvolvidos cuja lógica de distribuição de bens e serviços não se paute pela universalidade de cobertura (Bashshur 1987).

A ampliação e sofisticação crescentes do conhecimento humano, tanto no campo propriamente médico, como naqueles relacionados a seus insumos básicos indústria mecânica, farmacêutica, informática, etc. - têm levado, nas últimas 
décadas, a uma intensa incorporação de novas tecnologias ao processo de trabalho em saúde, com aumento acentuado da complexidade da assistência médica, particularmente no mundo ocidental, predominantemente formado por economias capitalistas. Nos paises pobres ou em desenvolvimento, a incorporação das técnicas modernas aos recursos de saúde existentes acompanha com dificuldade a velocidade das novas descobertas, devido aos altos investimentos financeiros envolvidos nesse processo.

Embora algumas novas tecnologias - mesmo contando com um alto custo inicial - tenham sido divulgadas como sendo economicamente compensadoras devido à sua eficiência em substituir sequeências de procedimentos anteriormente utilizados, isto não se verifica na prática cotidiana. De fato, no dia-a-dia dos serviços é mais fácil somar-se o procedimento novo aos antigos do que efetivar-se a substituição de uns pelo outro, ocorrendo freqüentemente uma utilização irracional dos novos recursos ( Wlody 1995 ). Isto é: os elevados custos dos serviços médicos atuais não se devem unicamente aos altos preços das novas técnicas absorvidas, mas principalmente ao crescente volume e intensidade de procedimentos incluídos nos atos médicos ( Relman 1988 ). Vale lembrar que a cada nova tecnologia incorporada correspondem não só novos equipamentos, mas também capacitação de operadores, instrução de outros profissionais e do público usuário e, algumas vezes, novas instalações ou adaptações de área fisica. A mudança de fluxos operacionais, criação ou mudança de cargos e funções, e a integração de uma nova cultura a respeito dos procedimentos recém introduzidos também representam um custo indireto, muitas vezes mal avaliado no processo de incorporação das novas tecnologias.

A plena atualização e adaptação da rede de serviços de saúde aos avanços tecnológicos só é possivel nos paises mais ricos, ou, como no Brasil, nas chamadas "ilhas de excelência" dos serviços destinados a poucos e seletos usuários, não por acaso, quase que invariavelmente, os da classe econômica e socialmente privilegiada, que pode pagar por eles. ${ }^{?}$

\footnotetext{
7 Outras ilhas de excelência são encontradas em alguns hospitais universitários da rede pública, que funcionam como produtores de tecnologia e formadores de pessoal habilitado, por concentrarem a elite profissional da área da saúde e contarem com alguma forma de financiamento extra orçamentário. Esses serviços habitualmente apresentam uma demanda do grande público reprimida, ao lado de portas especiais para os pacientes ditos "diferenciados".
} 
O acentuado avanço tecnológico das últimas décadas pode ser sentido também nos consultórios médicos, mas é nos hospitais, onde os recursos diagnósticos e terapêuticos se concentram, que ele melhor se desenvolve.

Devido ao crescente avanço de alta complexidade tecnológica na Medicina, pelo menos duas ordens de problemas têm surgido nos países desenvolvidos, onde o uso dessas novas práticas se dá de forma mais intensa. A primeira delas diz respeito a seu alto custo, já citado, ultrapassando com facilidade o poder de financiamento até das sociedades ricas. A outra diz respeito aos limites de atuação da Medicina, uma vez que novas possibilidades terapêuticas podem ser criadas, sem que necessariamente correspondam a elas um aumento de saúde, ou que possam até mesmo produzir efeitos deletérios. Exemplos: a capacidade cada vez maior dos equipamentos médico-hospitalares de prolongar a agonia de pacientes em estado terminal irreversivel, ou a capacidade crescente de manipulação genética de material humano em laboratório. Essas situaçðes suscitam importantes questões éticas.

A literatura científica especializada tem contemplado, atualmente, essas questões polêmicas: as publicações médicas tradicionais têm trazido entre seus artigos, grande número de trabalhos com enfoques tanto econômico quanto ético. Palestras, cursos de especialização e conferências sobre esses temas, largamente divulgados nas escolas e imprensa médicas, atestam a sua importância entre os profissionais de saúde.

O debate nessas duas áreas está longe de seu fim: tanto a complexidade e a abrangência desses temas como a inesgotabilidade do processo de introdução de novas práticas na área médica que, constante e extremamente variado, atingindo, de formas diversas, quase todo o mundo, mantêm essas questões candentes. Também os meios de comunicação de massa têm abordado esses temas, com grande repercussão na sociedade geral, nos países desenvolvidos e em desenvolvimento.

Importante notar que, nas diversas sociedades, a simples viabilidade econômica não é garantia de aceitação e legitimidade para uma nova prática. Em outras palavras: o que é financeiramente viável para uma determinada sociedade não é necessariamente considerado aceitável do ponto de vista ético por essa mesma população. Encontram-se exemplos dessa situação nas polêmicas suscitadas - entre a 
população leiga e também entre especialistas - por temas como a delimitação de tratamento fútil, autonomia médica e do paciente ( Jecker 1995, Helft et al. 2000 ), indicações de ressuscitação cárdio-respiratória ( Tomlinson e Brody 1990, AMA 1991 ) e prolongamento artificial da vida em situações consideradas clinicamente irreversíveis ( Finucane 1999, Williams 2000 ).

Por outro lado, o conjunto básico de serviços de saúde disponível hoje nos paises desenvolvidos, pode não ser - e quase sempre não é - economicamente viável para outras populações. Em um mundo onde a circulação de informações é cada vez mais rápida e abrangente, onde a divulgação publicitária de novos produtos para o consumo se dá massiva e ostensivamente, as carências surgem facilmente. Desse modo, populações sem recursos suficientes para o financiamento de determinados produtos e/ou procedimentos podem vir a considerar eticamente inaceitável sofrer a sua privação. Exemplos dessa situação são: disponibilidade da terapêutica antiretroviral combinada para os doentes de aids ${ }^{8}$, disponibilidade de leitos hospitalares de terapia intensiva para a população néo-natal de alto risco, em países pobres ou em desenvolvimento, como o Brasil.

Apesar das múltiplas questões suscitadas, a complexidade tecnológica crescente na assistência à saúde - principalmente no que diz respeito à assistência médica - tem trazido inegáveis progressos para a maioria das pessoas, aumentando a longevidade e propiciando uma melhor qualidade de vida. As conquistas médicas tanto se referem à prevenção das doenças, como o desenvolvimento de vacinas mais eficazes, quanto à evolução dos métodos diagnósticos e terapêuticos, permitindo deteç̧ão mais precoce e tratamentos bem mais potentes de grande número de doenças. A fascinação do público leigo, usuários reais ou potenciais dos serviços, bem como o otimismo e confiança dos profissionais de saúde na chamada tecnologia de ponta têm, portanto, bases concretas. Ademais, essa tendência de complexificação tecnológica na área da saúde é um fato aparentemente irrevogável, em todo o mundo ocidental, incluindo o Brasil.

\footnotetext{
${ }^{8}$ A terapêutica específica para aids atualmente recomendada combina várias drogas que atuam contra o virus da imunodeficiência humana - as drogas anti-retrovirais - com mecanismos de ação diferente, para potencializar seu efeito. A combinação de três ou quatro drogas anti-retrovirais constitui os chamados "coquetéis" para tratamento de aids
} 
$\mathrm{O}$ uso intensivo de tecnologias sofisticadas, tanto para fins diagnósticos como terapêuticos, é francamente incentivado pelos modelos de pagamento de serviços da maioria desses países - principalmente nos Estados Unidos da América como também exerce grande atração científica nos centros de ensino e pesquisa. As especialidades médicas mais dependentes de tecnologia de ponta gozam de maior prestigio e dão maior retorno financeiro que as demais ( Ham 1996 ).

No entanto, a supremacia do modelo acima citado não se deu sem lutas com seus opositores; isto é: não é um modelo totalmente hegemônico, e várias correntes de pensamento têm se colocado contra ele, por diversas razões, com maior ou menor graus de competência e sucesso.

Nos países desenvolvidos e particularmente nos Estados Unidos da América, onde a incorporação tecnológica massiva se deu primeiramente, algumas contracorrentes culturais se pronunciaram contra essa tendência, já em meados dos anos 60. Subsidiárias de movimentos sociais mais amplos: do movimento "hippie" de revalorização da Natureza, do movimento feminista, ou de ideários políticos e ideológicos anti-capitalista, essas contracorrentes se opuseram ao avanço tecnológico geral - considerado excessivo e deletério ( Abel 1986 ).

No contexto da assistência à saúde essas correntes culturais propunham o refreamento das intervençð̃es médicas nas situações consideradas eventos naturais, como nascimento e morte, bem como a limitação da medicalização dos atos do cotidiano. Faziam restrições ao "hospitalocentrismo" da assistência médica corrente, e ao avanço do domínio das máquinas e equipamentos sobre as relações humanas. Foi o momento do ressurgimento do parto natural domiciliar, do uso de remédios caseiros, de técnicas alternativas de cura e, em menor escala, da crítica à morte escondida e solitária nos hospitais ( Paradis 1985, Abel 1986 ). Esses questionamentos despertaram debates em torno da necessidade de "rehumanização" da Medicina e da maior participação do paciente ou de seus responsáveis nas tomadas de decisão em tratamentos de saúde. Os direitos do paciente - como sujeito e não objeto do tratamento - começaram a ser discutidos e definidos, e a alienação de sua condição de saúde, freqüente nos pacientes internados, foi identificada como um entrave à recuperação do doente, devendo ser evitada (Amenta 1985 ). 
No final dos anos 60 , em alguns países europeus, particularmente Itália, Inglaterra e França, surgiu um movimento reformador contra o modelo vigente de tratamento aos doentes mentais, conhecido como "anti-psiquiatria". Liderado por psiquiatras e outros profissionais da área de Saúde Mental, veio, portanto, de dentro da própria instituição assistencial, propondo uma nova forma de assistência a esses doentes. Basicamente, o novo modelo de atendimento repudiou o hospitalocentrismo e a exclusão social característicos da assistência psiquiátrica corrente, cruéis e desagregadores, estimulando os tratamentos ambulatoriais ou em hospital-dia e a reintegração dos pacientes em suas comunidades ( Kinoshita 1990, Silva F 1987 ).

A visão idealizada de uma sociedade sem manicômios, parcialmente viabilizada nos anos 60 pelas novas conquistas técnicas da indústria farmacêutica, foi experimentada com certo sucesso em alguns centros italianos, como na cidade de Trieste ( Kinoshita 1990, Silva $F^{\circ} 1987$ ). Logo, o movimento anti-psiquiátrico ultrapassou as fronteiras dos setores especializados e grupos diretamente interessados. Divulgado amplamente, foi incorporado por um segmento significativo de formadores de opinião pública, atingindo parte da população geral, em países da Europa e também nos Estados Unidos, nessa década ( Guattari 1985 ). Também aqui no Brasil, no final dos anos 70 e início da década de 80, as péssimas condições de tratamento de pacientes internados nos hospitais psiquiátricos públicos e privados, expropriados de direitos humanos básicos, foram objeto de acalorados debates, realizados tanto em fóruns acadêmicos como em espaços públicos. Os meios de comunicação de massa devassaram as portas das instituições psiquiátricas asilares, desvelando seu interior ao horrorizado olhar leigo, antes alheio a essa situação. A população passou a conhecer, então, uma equivocada forma da assistência médica vigente, talvez uma das mais ineficazes e perversas dos tempos recentes.

$\mathrm{O}$ abandono da quase obrigatória internação dos doentes mentais, advindo das novas alternativas de assistência, trouxe a esses pacientes um tratamento mais eficaz, mais humano e com menos sofrimentos ( Kinoshita 1990, Silva F 1987 ). Os profissionais de saúde, os pacientes e seus familiares, bem como a população geral, envolvidos nessa mudança, travaram um proficuo debate, criaram e experimentaram alternativas, implementaram soluções. O que estava em jogo era nada menos que as 
possibilidades concretas de tratamento digno e eficaz, e o resgate da cidadania dos pacientes.

Importante lembrar que os direitos gerais dos pacientes, a responsabilidade e o poder médico e das instituições de saúde já vinham sendo questionados nos países mais desenvolvidos, a propósito das tendências modernas em curso. A substituição da velha e confortável relação médico-paciente pela nova relação instituição-paciente, a fragmentação do atendimento médico em inúmeros procedimentos mediados por outros profissionais e seus equipamentos, o aumento do consumo de bens e serviços médicos, etc., não só traziam insegurança aos pacientes e um certo grau de desumanização da assistência médica, como também tornavam obsoletos os regulamentos éticos e legais existentes a esse respeito (Geiger 1975 ).

Também datam dessa época, anos 70, o movimento social pelos direitos dos consumidores, em um clima geral francamente anti-autoritário e anti-burocrático. Não é de se estranhar que os usuários de serviços de saúde, reais e virtuais, se incomodassem com o franco autoritarismo da instituição médica, a rigidez dos estabelecimentos de saúde, o papel passivo imposto aos pacientes sob tratamento. A pouca permeabilidade da Medicina a crítica e opinião não especializadas, no entanto, constituía - e constitui ainda - um dificil entrave às considerações éticas e técnicas vindas de fora de seu seio. $O$ aparecimento da Bioética ${ }^{9}$, como articuladora de respostas às indagações colocadas pelos avanços tecnológicos modernos na área da saúde - reprodução humana assistida, engenharia genética, transplantes de órgãos, prolongamento artificial e decisões referentes ao fim da vida - e pela distribuição social dos bens e serviços - eqüidade no acesso, definição de prioridades - também veio responder a algumas dessas questðes.

Toda essa movimentação no cenário histórico social - com seus avanços e conflitos, vividos tanto pelos profissionais como pelos usuários dos serviços de saúde e sociedade geral - tem contribuido para a ampliação do questionamento dos modelos de assistência à saúde, particularmente da assistência médica corrente no mundo ocidental. A riqueza de fatores, internos e externos ao setor, envolvidos no

9 Segundo Fortes, a Bioética é o ramo da Ética que trata das ciências da vida e dos cuidados de saúde, buscando a harmonização dos interesses individuais ( pacientes, profissionais de saúde ) e coletivos ( Fortes 1998 ). 
desenrolar histórico recente da prestação de cuidados de saúde pôde engendrar diversas críticas ao modelo hegemônico atual, favorecendo o aparecimento de propostas alternativas.

Por último, mas não menos importante: a mobilidade constante dos perfis demográfico e epidemiológico das populações acrescentam importantes impulsos à dinâmica dos serviços de saúde, tanto levando ao abandono daquelas práticas tornadas desnecessárias, como incrementando a demanda por ações e serviços mais adequados à clientela. A diferentes perfis de usuários - reais e/ou potenciais correspondem diversos modelos de assistência.

$O$ aumento da expectativa de vida verificado nas sociedades modernas, inclusive em países ainda em desenvolvimento, vem adicionando às populaçð̃es um contingente de idosos cada vez maior. A maior longevidade aumenta a exposição a riscos variados e ao processo de degenerescência, fazendo aumentar o número de pessoas doentes e de portadoras de seqüelas na população. Isto é, os velhos padecem de mais doenças crônico-degenerativas e de restrições funcionais que os demais, notadamente de doenças cárdio-vasculares e neoplásicas ( Waldman 2000 ).

Cuidar de pacientes com muitas debilidades e dependentes de cuidados para as atividades cotidianas requer uma estrutura assistencial especial. $O$ atendimento domiciliar, com o engajamento ativo da sociedade, tem sido uma solução para esses casos nos países desenvolvidos, particularmente na Europa e até mesmo em países como a China ( Melin et al. 1993, Xu \& Hu 1996). Introduzido nos Estados Unidos da América no final dos anos 70 , para diminuir a duração e custo das internações hospitalares, o atendimento domiciliar logo despontou como uma das formas de assistência mais crescentes nesse país, ao tornar-se um dos modos principais de atendimento de longa duração dirigido aos doentes crônicos, chegando até mesmo a incorporar alta tecnologia ( Arras e Dubler 1995, Welch et al. 1996 ). A maioria dos países desenvolvidos conta também com instituições para abrigar as pessoas dependentes de cuidados que não contam com cuidadores próprios, que então passam a viver albergados institucionalmente, sob cuidados constantes de enfermagem, como ocorre nas "nursing homes" americanas e hospitais geriátricos franceses, combinando assistência social e de saúde (Onyemelukwe e Delfs 1995, Moulias e Mémin 1988). 
Um outro grupo de pacientes que tem solicitado assistência especializada, nos últimos anos, em quase todos os países do mundo, é o dos doentes de aids. A emergência dessa síndrome, no final da década de 70, com rápida evolução para uma franca pandemia, trouxe mudanças drásticas ao perfil de morbi-mortalidade das populaçð̃es acometidas, gerando demandas inesperadas aos serviços de saúde.

A imunodepressão causada pelo HIV ( Human Immunodeficiency Virus = vírus da imunodeficiência humana ) torna os doentes de aids vulneráveis a numerosas doenças, infecciosas - chamadas de oportunistas - ou neoplásicas, fazendo com que os pacientes de aids necessitem, muitas vezes, de tratamento intensivo agudo, geralmente em regime hospitalar. Condiçð̃es patológicas decorrentes da própria aids ou de suas intercorrências, como: debilidade, desnutrição, distúrbio mental, etc., também podem requerer assistência médica hospitalar. A terapêutica e a profilaxia das doenças oportunistas e neoplásicas podem obrigar os pacientes a tratamentos prolongados, com administração de drogas por pessoal de enfermagem, tornando-os cronicamente dependentes de assistência especializada, em regime ambulatorial ou em hospital-dia. A alta letalidade da aids ${ }^{10}$ leva a uma procura de serviços hospitalares com o objetivo preciso de assistência ao doente em fase terminal - ainda hoje - embora o aperfeiçoamento das terapeuticas anti-retroviral e anti-microbianas tenham levado, nos últimos anos, a uma acentuada diminuição tanto do número de intercorrências quanto do número de óbitos desses pacientes (Zucconi et al. 1994, Michaels et al. 1998, Mocroft et al. 1999 ). De fato, a introdução recente dos novos esquemas de tratamento para esses doentes levou a uma acentuada queda das internações hospitalares e da mortalidade por aids, nos países que o fizeram, entre eles o Brasil (Palella et al. 1998, Casseb et al. 1999, Weidle et al. 1999 ). Apesar de importantes conquistas terapêuticas, ainda não se pode falar em cura da doença; os especialistas recomendam uma atitude cautelosa na indicação do tratamento e no manejo das drogas, sendo necessários a supervisão de médicos experientes e

\footnotetext{
${ }^{10}$ Apesar da acentuada diminuição de mortalidade por aids conseguida com o uso das novas drogas anti-retrovirais, ainda não foi possivel conseguir a cura dessa doença, mas apenas seu controle, por tempo indefinido ( Condra 1998, Poggi et al. 1999 ). A letalidade da aids é considerada alta até hoje, uma vez que, mesmo de evolução prolongada, ela continua como causa básica de morte da imensa maioria dos pacientes por ela afetados.
} 
controle laboratorial, uma vez que o seu uso pode facilmente levar a resistência viral e a intolerância (Gulick 1998, MS 1999 c, Nadler 1999 ). Além disso, a dificuldade de instituição de tratamentos adequados em todos os casos, tanto por dificuldades de acesso como de adesão " ao tratamento ainda deixa muitos doentes à mercê da progressão da aids até a sua morte (WHO 1999, Levi e Kates 2000 ).

Desde o aparecimento dessa síndrome, há pouco mais de duas décadas, a morte de pacientes jovens cresceu em todas as regiões do mundo onde ela grassa, aumentando a procura de assistência à fase terminal desses pacientes. Num passado não muito distante, no início da pandemia, os hospitais tiveram que se adequar a situações em que a escolha terapeutica preferencial era, na maioria das vezes, a paliativa (Rosemblum et al. 1992 ). Não obstante os grandes progressos conquistados, as soluções adequadas ao equacionamento desse problema ainda parecem remotas, particularmente nos países pobres e em desenvolvimento ( Selwin 1996, WHO 1999).

A plasticidade dessa pandemia e a rapidez com que tem suscitado o surgimento de recursos tecnológicos para seu enfrentamento são notáveis. $O$ grande número de infectados e doentes - 33,6 milhões, ao final de 1999, segundo dados da Organização Mundial de Saúde ) que estima-se existirem hoje em todo o mundo, incluindo nosso país, bem como a incidência ainda elevada de novos casos, no entanto, continuam indicando a necessidade de redimensionamento e adequação dos serviços para o atendimento aos doentes (Gulick 1998, WHO 1999, Levi e Kates 2000 ).

\section{As novas práticas assistenciais}

Pressionados pelo aumento e diversificação da demanda geral por serviços, pela escalada assustadora dos custos da assistência médica, e questionados pela sociedade geral ou seus grupos, quanto à qualidade dos serviços prestados, os

\footnotetext{
$"$ Um estudo pioneiro no Brasil, realizado recentemente no Estado de Săo Paulo, verificou uma prevalência de aderência ao tratamento anti-retroviral de apenas $69 \%$. Longe do desejável, segundo sua autora, mas semelhante a prevalências encontradas nos países desenvolvidos. $O$ estudo considerou como aderente ao tratamento os pacientes que reportaram ter tomado $80 \%$ ou mais dos comprimidos prescritos, durante os três dias que antecederam a entrevista (Nemes 1999 ).
} 
administradores de saúde de vários países vêm se deparando, desde o início dos anos 80 , com o que a mídia tem chamado, indistintamente, de crise da saúde.

A insatisfação geral tem propiciado a criação e experimentação de novos modelos e/ou formas de atendimento aos problemas de saúde, e também a ampliação e consolidação de práticas incipientes, primeiramente nos países desenvolvidos, e particularmente nos Estados Unidos da América, onde a reforma do sistema hospitalar urgia, devido a intoleráveis pressões econômicas ( Sochalski 1997)

Assim, verifica-se que nos países do primeiro mundo o atendimento hospitalar tradicional, dispendioso e cada vez mais mediado por máquinas e aparelhos, vem cedendo espaço a formas alternativas de atendimento, para aqueles casos que não necessitam assistência intensiva. São elas:

- regime de semi-internação, nos chamados "hospital-dia" para os pacientes que podem passar a noite em seu domicílio;

- alocação de pacientes em estado terminal em instituição ou regime especial de tratamento paliativo, conhecidos como atendimento tipo "hospice" ${ }^{12}$;

- tratamento de pacientes crônicos e dependentes de ajuda em instituições hospitalares de retaguarda (Boquet 1989, Goldstone et al. 1995 );

- atendimento domiciliar por equipe multiprofissional ( Drummond e Davies 1988, Melin et al. 1993 );

- substituição, sempre que possível, do regime de internação pelo atendimento ambulatorial, até mesmo para pequenas cirurgias.

A adaptação do atendimento médico hospitalar aos tempos modernos é uma das razões apresentadas para a adoção de algumas novas práticas, como no caso das pequenas cirurgias e procedimentos diagnósticos ambulatoriais, mesmo que o seu impulso mobilizador principal tenha caráter preponderantemente econômico: a contenção de custos, pelo lado dos provedores de serviços, e a pressão do mercado dos equipamentos e insumos médico-hospitalares, pelo lado de seus fabricantes. $O$

\footnotetext{
${ }^{12} \mathrm{O}$ conceito "hospice" de assistència - $e$ as instituições conhecidas por esse nome - visam a qualidade de vida, o controle efetivo dos sintomas e o atendimento ao paciente e familiares, através de uma atuação multidisciplinar integrada, enfocando as necessidades físicas, psíquicas, sociais e espirituais do paciente em fase terminal ( Rhymes 1990 ). O objetivo do tratamento é ajudar o paciente a viver da melhor maneira possível a sua vida, até a sua morte, e a morrer em paz ( Saunders 1995 ).
} 
fato inegável é que os recursos tecnológicos modernos criaram as condições para que certos procedimentos terapêuticos pouco complexos possam ser realizados até mesmo durante atendimento domiciliar. As novas práticas também beneficiam indiretamente a economia geral, ao levarem à diminuição dos períodos de internação e, conseqüentemente, a menores interrupções das atividades para tratamento da saúde, por parte da população economicamente ativa. A menor permanência dos pacientes - especialmente os imunologicamente comprometidos - nos hospitais diminui as chances de infecções hospitalares, constituindo outra vantagem das novas práticas ( Cavalcante 2000 ).

Outra justificativa para a adoção de novas formas de atendimento é a importância de, ao lado da recuperação física, intentar-se também melhorar o bem estar psíquico e social do paciente, humanizando a assistência. Algumas novas práticas são realizadas, sempre que possível, fora da rigidez e impessoalidade do ambiente hospitalar convencional, envolvendo ativamente os familiares e amigos dos pacientes. É o caso do atendimento domiciliar, geralmente dirigido a portadores de doenças crônicas, e do atendimento paliativo a doentes terminais, realizado domiciliarmente ou em enfermarias hospitalares e/ou serviços especiais, como a assistência realizada segundo o modelo "hospice".

$\mathrm{O}$ atendimento domiciliar é uma forma de prestar serviços de saúde levando os recursos à moradia do paciente, ao invés de transportar o paciente para um centro diagnóstico e/ou terapêutico. É uma modalidade de prestação de assistência baseada em recursos da própria comunidade, no que se refere ao alojamento e cuidados constantes ao paciente, e na mobilidade das equipes técnicas e seus equipamentos, que se deslocam para supervisionar e realizar a parte especializada do atendimento.

Nos Estados Unidos da América o atendimento domiciliar surgiu em meados dos anos 80 como um recurso para acelerar as altas hospitalares geralmente pós cirúrgicas - e consistia, inicialmente, de visitas domiciliares de enfermagem. Visava diminuir os periodos de internação e também os episódios de reinternações e só se destinava aos pacientes egressos dos hospitais (Welch et al. 1996). Atualmente o atendimento domiciliar em saúde é prestado maioritariamente a doentes que necessitam de cuidados e supervisão de saúde constante. $O$ atendimento 
domiciliar, que passou a ser largamente utilizado nesse pais no final dos anos 80 , é realizado pelas agências públicas e privadas, incorporou o uso de alta tecnologia e teve um crescimento explosivo, constituindo o setor econômico de mais rápido crescimento na indústria da assistência à saúde. Esse rápido desenvolvimento agora começa a exigir avaliações da qualidade dos serviços prestados e suscita questões éticas a respeito do envolvimento de não profissionais na manipulação de pacientes e de equipamentos complexos ( Arras e Dubler 1995 ).

$\mathrm{O}$ atendimento domiciliar também é bastante utilizado em outros paises desenvolvidos, como Alemanha e Canadá ( Sochalski et al. 1997 ), havendo relatos de seu uso para o atendimento de idosos também na China, como já citado.

Com a transformação da aids em uma doença crônica ${ }^{13}$, requerendo atenção a longo prazo, as instituições governamentais americanas passaram a estimular o uso desses serviços, para evitar internações hospitalares e assim diminuir os custos de tratamento ( Cruise 1994, Smith 1994 ). Estudos de custo-beneficio desses programas de atendimento referem melhora significativa na recuperação dos pacientes tratados domiciliarmente, devida à sua participação ativa nesse processo, mormente quando se trata de pacientes jovens, o que é comum nos casos de aids ( Smith 1994 ). No entanto, nem todos os pacientes podem se beneficiar dessa modalidade de assistência. As limitações mais comuns ao tratamento em regime domiciliar são: comprometimento neurológico importante, uso de drogas, condiçð̃es de moradia precárias, e morar sozinho ( Poisson-Salomon et al. 1995 ).

Desde que o hospital - local onde se concentram, hoje em dia, os procedimentos diagnósticos e terapêuticos com maior uso de tecnologias complexas - vem se dedicando aos cuidados mais intensivos, surgiu a necessidade de transferir a outros espaços a assistência aos doentes que não requerem esses cuidados durante todo o dia, mas que não podem ser tratados ambulatorialmente ou em seu domicílio. O hospital-dia foi então implantado, como uma alternativa intermediária entre a internação e o tratamento ambulatorial, para aqueles pacientes que necessitam atendimento do tipo hospitalar não intensivo, de modo intermitente, durante um

\footnotetext{
${ }^{13}$ Embora hoje em dia a aids se apresente como uma doença de longa evolução, não se pode esquecer que o seu padrão de assistência mostra forte paralelismo com a assistência prestada a doenças agudas (Clarke 1994 ).
} 
certo período de tempo, como no caso da administração de medicamentos sob supervisão médica ou de enfermagem ( Adler 1987). O hospital-dia pretende aumentar a eficiência do uso dos leitos hospitalares, reservando-os para o atendimento a episódios agudos e críticos, sem no entanto deixar de disponibilizar recursos hospitalares para aqueles pacientes que necessitam de cuidados especializados de longa duração ( MS 1988, Atkins e Kohn 1992 ).

Bastante utilizado no atendimento a pacientes com doenças mentais, tendo sido desenvolvido a partir do movimento de desospitalização psiquiátrica, o hospitaldia supre as necessidades terapêuticas dos pacientes ao longo do dia, fazendo-os retornar às suas casas ao final do período. $O$ hospital-dia baseia-se em uma solidária ligação entre o hospital e a comunidade. De fato, algumas das dificuldades para a indicação desse regime de assistência a certos pacientes crônicos são sociais ( falta de moradia, de suporte social, uso de drogas ), e não decorrentes de seu quadro clínico ( Smith MY et al. 1992).

No caso dos pacientes com aids é freqüente a necessidade de administração prolongada de drogas, em regime profilático ou terapêutico, com controle médico e/ou de enfermagem. Às vezes são necessárias condições especiais ambientais, como por exemplo no uso de pentamidina, para a profilaxia da pneumocistose, que deve ser inalada, em aerossol. O hospital-dia representa, para esses pacientes, a possibilidade de receber o tratamento adequado sem necessidade de internação. Alguns estudos mostram o aumento do uso de hospital-dia, na Europa e nos Estados Unidos, como alternativa de tratamento a esses doentes, com bons resultados ( Adler 1987. Thelot e Monteil 1992, Johnson et al. 1993 ).

A internação convencional, o atendimento em regime de hospital-dia e o atendimento domiciliar podem ser realizados pela ótica da assistência tipo hospice, quando se tratar de cuidados aos pacientes em fase terminal. Esse termo refere-se tanto a um programa ou forma de assistência, como ao local onde esse tipo de cuidado é realizado ( Paradis 1985 )

O conceito hospice de assistência tem como objetivo reduzir o desconforto físico e psíquico do doente em fase final, e não a sua cura. Não procura prolongar, mas sim melhorar a qualidade de vida restante ao paciente. Para isso, utiliza-se de 
terapêuticas paliativas - diminuição ou eliminação da dor e de outros sintomas - e de tratamento de suporte: hidratação, nutrição, como também de apoio mental, social e espiritual, realizados por uma equipe multiprofissional e envolvendo, sempre que possível, familiares e amigos do paciente no processo de assistência ( Paradis 1985, Wanzer et al. 1989)

Essa forma de assistência se fundamenta na assunção de que os pacientes para os quais as terapias curativas tenham se esgotado, e que portanto não mais se beneficiam desses tratamentos, podem e devem receber assistência integral - física, psicológica, espiritual, social - que lhes diminua os sofrimentos e lhes proporcione a melhor qualidade de vida possivel, ao final dos seus dias. Esse modelo de assistência envolve não apenas o doente, mas também seus familiares, auxiliando-os a assistir ao doente e preparando-os para a sua perda iminente ( Saunders 1991, Paradis 1985 ).

Um dos motivos principais para o surgimento e expansão dessa forma de assistência advém do fato de que muitas pessoas - leigas e profissionais de saúde tenham percebido que os hospitais convencionais, onde a maior parte das pessoas vem a morrer nos paises ocidentais, nos dias de hoje, têm dispensado cuidados muito precários aos pacientes que estão morrendo, e que essa inadequação às necessidades dos pacientes é, também, desnecessariamente custosa (Osterweis e Champagne 1979, Mills et al. 1994 ).

O movimento hospice será descrito mais adiante, ao se apresentar um breve histórico das formas de assistência aos doentes terminais. Por ora vale referir a sua importância nos países desenvolvidos, e sua rápida aceitação e crescimento nos Estados Unidos da América, onde surgiu em meados dos anos 70 , tendo assistido a pouco mais de 8 milhões de pacientes só no ano de 1995 ( Haupt 1998 ).

Outras formas de assistência ao doente terminal surgiram, em meados dos anos 70, nos Estados Unidos da América, como decorrência dos movimentos sociais da época, já referidos ( Thiermann 1991 ). O conceito hospice de atendimento, adaptado do modelo original inglês, no entanto, foi aceito amplamente pelos profissionais de saúde e população geral americanos, tendo sido rapidamente incorporado ao sistema de saúde daquele país (Osterweis e Champagne 1979, Abel 1986 ). Quase todos os países desenvolvidos - da América do Norte, Europa; e ainda a Austrália, e até o Japão contam com serviços hospices em seu sistema de saúde. Alguns países pobres ou em 
desenvolvimento - do leste europeu, da América do Sul e da África - também têm serviços de atendimento a doentes terminais segundo a filosofia hospice. A expansão de seus princípios básicos - alivio de sintomas, importância da comunicação, suporte à família, trabalho multiprofissional - e o desenvolvimento de um novo campo de conhecimento e de práticas em saúde - dos cuidados paliativos - vêem ocorrendo em todo o mundo ( Saunders 1991, Merriman 1991, Rico 1997, Luczak e Hunter 2000 )

\section{Definição de prioridades e conformação da rede assistencial}

A variedade de tipos de serviços de saúde atualmente conhecidos possibilita a montagem de um sistema diversificado de atendimento, de modo a contemplar tanto as carências expressas pela demanda e aquelas não expressas, quanto a disponibilidade de recursos existentes. Em outras palavras: existem, hoje, numerosas possibilidades de composição dos serviços para o atendimento das questões de saúde de uma dada população, de forma a adequar-se às suas necessidades.

Importante lembrar que a adequação ou não dos serviços à resolução dessas necessidades, isto é, sua eficácia e efetividade, constituem uma questão de ordem técnica, enquanto que o acolhimento e legitimação das mesmas necessidades constituem questões politicas, sendo resultante do embate entre as forças sociais em jogo.

Definir quais ( para responder a que necessidades ) e quantos serviços ( para que volume de atendimentos ), onde localizados e como atuando ou com qual modelo operacional ( para acesso de qual contingente populacional ) são necessários para uma dada população, em um certo momento é, portanto, um problema simultaneamente técnico e político.

A identificação e seleção dos problemas que devem ser solucionados, isto é, a proposição de políticas e práticas de saúde envolve, necessariamente, numerosos fatores, alguns bastante complexos. Entre eles: os modos/modelos possíveis de atuação, os propósitos e incertezas próprias da área da saúde, bem como a dinâmica das forças sociais - políticas, econômicas, culturais - envolvidas no processo decisório ( Barrenechea 1971 ). Na definição de uma política de saúde deve-se 
considerar, entre outros: as características demográficas e epidemiológicas da população a ser atendida, seu contexto social - incluindo hábitos e valores - e seu meio ambiente, a situação de saúde que se pretende alcançar e, por último, mas não menos importante, os recursos disponíveis para operacionalizar a política proposta.

Não se pode ignorar que as necessidades são estimadas de modo diverso, entre as várias categorias profissionais e pelos leigos usuários dos serviços de saúde ( Charles et al. 1997 ). A identificação de carèncias varia, em cada grupo populacional, de acordo com as experiências concretas de vida de cada um (Wennberg 1985 ). Devido à complexidade desse tema, uma discussão mais detalhada sobre necessidades será apresentada à frente.

A questão da quantidade de serviços ofertados às populações já vem sendo objeto de muitos estudos, nas últimas décadas. Parâmetros referentes a número mínimo ideal de recursos materiais e humanos ( unidades básicas, hospitais e leitos hospitalares, profissionais de saúde, etc. ), recomendados por instituiçőes da área de saúde com credibilidade internacional, como a Organização Mundial de Saúde, podem ser encontrados nas publicações médicas de grande circulação. Embora o alcance e limitaçăo desses índices possam ser questionados, os seus mecanismos de construçăo também já têm sido bastante discutidos, possibilitando a sua utilização mais criteriosa.

Ao se equacionar os serviços necessários - tipo, quantidade, distribuição - à execução da política de saúde proposta, depara-se obrigatoriamente com dois imperativos aparentemente contrapostos: conter custos e manter um nivel aceitável de qualidade desses serviços.

A contençăo de custos, longe de se limitar à racionalização das práticas utilizadas, no sentido de evitar desperdícios e aumentar a eficiência dos recursos existentes, significa também realizar escolhas dificeis, como priorizar grupos para atendimento, às custas da exclusão dos demais, ou escolher, dentre determinados problemas de saúde, quais receberão maior atenção, em detrimento de outros. Isto é, uma vez que as demandas por bens e serviços relacionados à saúde são praticamente ilimitados, sempre que se oferecer um serviço para suprir uma carência, outra carência deixará de ser atendida ( Williams 1988 ). Para aquelas situaçð̃es em que a 
maior parte da população já se encontra abaixo do limiar de saúde aceitável, a contenção de custos é um problema de dificil solução.

Em se tratando de atendimento hospitalar, isto é, na estrutura mais cara do sistema de assistência à saúde, uma das formas que a contenção de custos tem assumido, como já vimos, é a restrição das internações, tanto reduzindo sua duração como seu número ( Jolly e Gerbaud 1992 ). Alternativas como a busca da eficiência máxima dos procedimentos, o corte de desperdícios e supérfluos, preservando-se o melhor possível a qualidade do atendimento, têm menor impacto econômico e são, usualmente, tecnicamente mais dificeis ( Azevedo 1992 ).

A qualidade dos serviços na área da saúde é de difícil caracterização e, igualmente à noção de necessidade, é vista de modo diferente pelos técnicos de saúde e pelos usuários do serviço (Atkinson 1993 ). A sua mensuração é um problema complexo, uma vez que não apenas a resolutividade tecnológica - o processo - está sendo avaliada, mas, ao mesmo tempo, o resultado obtido através das práticas em questão, isto é: a melhora do estado de saúde atribuivel ao procedimento. ${ }^{14}$

A dificuldade adicional trazida pelo objeto saúde, por si só de difícil conceituação, faz com que a problematização da qualidade das práticas executadas pelos serviços de saúde se torne um debate extremamente escorregadio.

A qualidade é um juizo de valor, uma “comparação do que é com o que deveria ser" ( Nogueira 1995, p. 38 ). Tal como percebida pelos profissionais de saúde, a qualidade dos serviços relaciona-se com o conhecimento e tecnologia disponíveis no momento ( Donabedian 1988 ). A qualidade do atendimento, tal como percebida pelo usuário, relaciona-se às suas expectativas em relação ao serviço em questão e tem sido medida, em alguns estudos, pelo seu grau de satisfação com o serviço ( Cleary e McNeil 1988, Cohn et al. 1991 ).

A qualidade das práticas de saúde, sob ambos os pontos de vista citados, e a satisfação do usuário, pela sua complexidade, serão objeto de maior detalhamento, a

\footnotetext{
14 Donabedian, autor clássico sobre qualidade dos servicos de saúde, sistematizou a abordagem das informações necessárias à avaliação da assistência, classificando-as sob três categorias: atributos referentes à estrutura onde a assistência é prestada; informaçôes sobre o processo desenvolvido, isto é, as atividades realizadas; informações sobre os resultados ou efeito dos cuidados na saúde do paciente ou população objeto da intervenção ( Donabedian 1988 ).
} 
ser apresentado em um próximo capítulo. Por ora cabe assumir que tanto uma como a outra são também moldadas socialmente. Isto é, são influenciadas pela valorização social das práticas em questão, pelo grau de conhecimento técnico de quem faz o juízo, pelas suas expectativas frente ao rol de alternativas disponiveis, pelo grau de cidadania da população que se serve dessas práticas e as avalia (Oliveira 1991 ).

Embora na prática cotidiana dos serviços essas questões - cortar custos e ao mesmo tempo garantir quantidade e qualidade satisfatórias de serviços - nem sempre se coloquem com clareza, é quase sempre delas que se estará tratando, no trabalho de prestar assistência à população, principalmente naqueles serviços que rotineiramente se vêem às voltas com excesso de demanda e recursos orçamentários insuficientes, isto é, na grande maioria dos hospitais da rede pública brasileira.

Enquanto muitos deles passam a gerir a escassez de recursos através da restrição da demanda, outros buscam recursos extra institucionais e/ou a substituição de algumas práticas, conforme suas possibilidades materiais e seu grau de autonomia administrativa. Isto é, para dar conta de seu papel no sistema de assistência à saúde, a administração do hospital moderno vem se percebendo forçada a considerar também a situação "extra-muros" - comunidade na qual se insere e seus recursos e valores, novas tecnologias, possibilidades e limitações econômicas e políticas ajustando-se em função das circunstâncias em que se encontra ( Carvalho 1988, Kisil 1988 ).

Aqueles serviços que não buscam soluções criativas de adequação à sua clientela correm o risco de enfrentar situações desagradáveis, tanto de ociosidade de seus recursos ( mais raramente, no Brasil ) quanto de excesso de demanda. Não se pode deixar de lembrar os riscos da absorção irrestrita da demanda, sem as condições minimamente adequadas ao atendimento. As internações em condições precárias, vistas freqüentemente nos prontos-socorros públicos, ultrapassando em muito o limite da capacidade operacional existente, podem levar a sério acometimento da qualidade dos serviços prestados. Do mesmo modo, a diminuição pouco criteriosa dos períodos de internação, resultando em altas precoces, pode resultar em graves complicações. Essas situações de inadequação do sistema assistencial de saúde fazem aumentar a pressão para melhoria desse sistema. 


\section{Serviços de saúde brasileiros e novas práticas assistenciais}

No Brasil, país em desenvolvimento, com grande disparidade na distribuição de renda, a assistência à saúde tem se caracterizado por um déficit crônico de recursos, de ordem financeira, material e humana. Esses recursos de saúde encontram-se distribuídos desigualmente, em todo o país, seguindo a lógica de mercado. Isto é, concentram-se nas regiões mais ricas, com maior poder de consumo. Esta distribuição se verifica tanto para as unidades básicas, de atendimento primário, quase que exclusivamente públicas, quanto para os hospitais especializados, públicos e privados, que fazem uso de tecnologia avançada. Nas áreas pobres, quando presentes, os serviços públicos são quase sempre dotados de recursos insuficientes, tanto em quantidade como em qualidade ( Cohn e Elias 1996 ).

Apesar de importantes iniciativas e conquistas no campo da prevenção de doenças, como a erradicação da poliomielite, o modelo de assistência à saúde predominante no Brasil, é o do tipo curativo, isto é, prioriza o atendimento ao doente. Tem como atividade nuclear a consulta médica, onde o hospital desempenha importante papel ( Cohn et al. 1991 ). A deficiente implantação de um sistema de saúde hierarquizado, cuja porta de entrada deve ser a unidade básica, faz com que o nível primário de atendimento à saúde seja realizado menos nessas unidades do que nos serviços hospitalares e de pronto-socorro. Isto é: a população deixa de procurar atendimento nos centros de saúde devido a dificuldades de acesso - horário de funcionamento, critérios de admissão, locomoção - e, principalmente, à baixa resolutividade dessas unidades, e ruma para as portas dos serviços de pronto atendimento, mesmo na vigência de condiçð̃es não elegíveis para o atendimento nesse tipo de serviço. Segundo dados do IBGE, foram realizadas 12 milhões de internações no país, no ano de 1996 ( IBGE 1998 ).

Embora o município de São Paulo disponha de uma razoável quantidade de leitos hospitalares ( 2,7 leitos por 1000 habitantes, pelo censo de 2000, disponivel em: < http://www.ibge.gov.br/cidadesat/ufs/sp.htm > [ Fev. 2001 ] ], sua distribuição é irregular, mesmo tratando-se dos serviços públicos, tornando-se bastante intensa ao se tratar dos equipamentos hospitalares privados. Dado que a maior parte dos 
recursos hospitalares existentes pertence ao setor privado da economia, eles tendem a se concentrar naquelas áreas onde existe maior poder de compra por parte de seus potenciais consumidores de serviços, deixando descobertas aquelas áreas onde a clientela não pode pagar para obter atendimento ( Cohn e Elias 1996 ).

A ausência de planejamento da distribuição dos recursos hospitalares de acordo com parâmetros epidemiológicos, faz com que coexistam, na região da Grande São Paulo, leitos ociosos para o tratamento clínico não especializado de adultos, em pequenos hospitais da rede filantrópica, e falta de leitos hospitalares para determinadas especialidades. Segundo o Plantão Controlador Metropolitano ( PCM ) da Secretaria de Estado da Saúde de São Paulo, que organiza a distribuição de vagas em leitos hospitalares públicos e filantrópicos da Região da Grande São Paulo, há carência, nessa região, de: leitos de terapia intensiva ( U.T.I. ), principalmente néonatal e pediátrica; de leitos para o tratamento de pacientes neuro-cirúrgicos; para gestantes de alto risco e para queimados, bem como de leitos de retaguarda para doentes crônicos dependentes de cuidados médicos e/ou de enfermagem ( segundo dados dos boletins internos do PCM./ SESSP, de 1999 e 2000 ).

$\mathrm{O}$ envelhecimento da população, no Brasil e também no Estado de São Paulo, já vem se evidenciando nos últimos censos populacionais. No entanto, poucos serviços públicos de saúde apresentam programas para atender às necessidades específicas desse grupo, encontrando-se $o$ atendimento ao idoso ligado, notadamente, a instituições de ensino e pesquisa. A pouca disponibilidade de leitos de retaguarda na rede pública hospitalar e uma apenas incipiente experiência de atendimento domiciliar, aliados à precariedade das instituições asilares, deixam a população idosa brasileira quase que totalmente desprovida de recursos de saúde adequados ( Grabois e Sandoval 1995, Chaimowicz 1997 ).

Na Grande São Paulo, soma-se à população que habitualmente procura os serviços hospitalares, um outro contingente populacional, característico do perfil de morbi-mortalidade dessa grande metrópole: é o das vítimas da violência, clientela hospitalar de grande gravidade, que já atinge dramáticas proporç̃̃es ( Pro-AIM 2000 ). Além disso, as condições insalubres de vida e precária rede de suporte social dessa 
região contribuem para uma maior morbi-mortalidade por doenças atribuiveis, total ou parcialmente, ao meio ambiente deteriorado e a um inadequado estilo de vida.

Dessa forma, um grande número de pessoas buscando assistência tem chegado às portas dos hospitais públicos da capital, superando a capacidade de atendimento desses serviços, incluindo também aqueles melhor capacitados a responder a tais demandas. É sobejamente conhecido que a procura dos pacientes pelo atendimento tem se acompanhado, nesses serviços, de longas esperas muitas vezes infrutíferas, de peregrinações por numerosos serviços, de assistência incompleta ou inadequada, de falta de recursos generalizados e de atendimentos de má qualidade (Cecílio 1997 ).

A rede pública hospitalar tem recebido, portanto, uma demanda por assistência maior que sua capacidade de atendimento, incluindo aquela parcela dos atendimentos que seriam desenvolvidos com maior eficiência em outros tipos de serviços de saúde. Nessa contingência, vigiar suas portas de entrada, e afunilá-las, tem sido a regra. Uma vez que a demanda excede suas possibilidades de resposta, o hospital tende a ser mais seletivo na absorção da clientela.

É nesta situação - de pletora de sua capacidade de atendimento - que o grande avanço tecnológico dos últimos anos veio encontrar a rede pública hospitalar na região de São Paulo. Nesse contexto, o surgimento e a implantação de novas práticas, como possíveis alternativas à internação hospitalar convencional, podem ser de grande valia.

Dentre as práticas introduzidas nos hospitais brasileiros, desde o final dos anos 70, podem se encontrar: ampliação da sua capacidade através da diminuição da duração do período de internação com correspondente aumento da rotatividade dos leitos disponíveis; substituição das internações com finalidade diagnóstica ou para a realização de procedimentos simples por atendimento em regime ambulatorial, ou por atendimento em regime de semi-internação ou de hospital-dia, este último modelo iniciado, como já referido, com a reformulação da assistência psiquiátrica.

A incorporação dessas novas práticas nos hospitais públicos da Grande São Paulo tem se realizado gradualmente. A inexistência ou indisponibilidade atual de estudos sobre as práticas correntes dificulta uma adequada avaliação da situação 
vigente. No entanto, publicações da grande imprensa e das associações médicas e empresas prestadoras de serviços de saúde têm divulgado, com certa freqüência, experiências inovadoras entre nós, de hospital-dia e de atendimento domiciliar. Aparentemente, algumas dessas práticas têm recebido uma boa aceitação, tanto por parte da população, como dos profissionais de saúde; outras, nem tanto. Enquanto umas são encaradas como uma evidente melhoria do sistema assistencial, outras são vistas com certa desconfiança. Aparentemente porque, como dito acima, ainda não se encontram publicações abrangentes na literatura científica; encontram-se relatos pontuais, e reportagens em jornais corporativos ou na chamada grande imprensa.

No município de São Paulo, algumas experiências de atendimento domiciliar já vêm ocorrendo há pelo menos duas décadas, embora em número bastante reduzido, dadas as proporçð̃es da clientela potencial. Entre os serviços públicos podem ser citados: o serviço pioneiro do Hospital dos Servidores Públicos de Estado, com pouco mais de duas décadas de existência, a Unidade de Cuidados Continuos do Hospital Pérola Byington, da rede estadual, dirigido majoritariamente a pacientes portadoras de câncer não responsivo à terapêutica curativa, o Núcleo de Atendimento Domiciliar da Clínica Médica do Hospital das Clínicas da FMUSP, o serviço de Atendimento Domiciliar Terapêutico ( ADT ) do Centro de Referência e Treinamento em Aids da Secretaria Estadual de Saúde. Este último faz parte da rede de serviços promovida pelo Ministério da Saúde para assistência aos pacientes com aids. Segundo o Ministério da Saúde, "a implantação dos serviços de ADT foi, inicialmente, movida pela necessidade de se ofertar alternativas às internações tradicionais, e pela possibilidade de humanização do atendimento, sobretudo aos pacientes em fim de vida." ( MS 1999 a, p. 37 ).

Também o Programa de Saúde da Família, da Secretaria Estadual de Saúde de São Paulo, de atendimento integral à família, desenvolvido inicialmente em alguns bairros carentes da zona leste do município, realiza visitas e atendimentos domiciliares como base de sua atuação. A ampliação desse projeto, considerado bem sucedido, constou como meta da Secretaria da Saúde, dentro do plano de governo para o ano 2000, bem como o desenvolvimento de estudos para a implantação de programas de atendimento domiciliar em todo o Estado ( São Paulo [ Estado ] 1999 ). 
Empresas privadas também têm atuado domiciliarmente, na região da Grande São Paulo, e vêm se especializando nessa área. Entre elas algumas já contam com mais de quinze anos de atividades. Algumas grandes empresas de saúde estão implementando, bem recentemente, a inserção dessa modalidade de atendimento em seus planos de saúde, o que certamente levará à ampliação desses serviços. Relatos de experiências pontuais podem ser encontrados em suas publicações, como o de uma empresa privada de atendimento domiciliar em São Paulo que refere mudança no perfil de morbi-mortalidade dos pacientes por ela assistidos, verificando maior gravidade dos pacientes e maior ocorrência do óbito domiciliar, ao comparar os atendimentos realizados em 1998 e 1999 (Medina e Fernandes 1999 ). É possível que esse relato esteja desvelando uma tendência geral, ainda a ser confirmada, mas é inegável que estejam ocorrendo mudanças nas práticas assistenciais realizadas também aqui, na região da Grande São Paulo.

$O$ atendimento em regime de hospital-dia é parte integrante da assistência aos pacientes com aids, nos serviços da rede pública estadual de saúde, desde há pouco mais de uma década. Forma intermediária entre atendimento hospitalar e ambulatorial, sua proposta básica é viabilizar a medicação assistida e a realização de procedimentos como biópsias. O hospital-dia foi incorporado ao programa nacional de aids devido à demanda crescente por assistência e à limitada resolutividade da rede hospitalar (< http://www.aids.gov.br/assistencia/aids1/relativ_alternativa.htm > [ Fev. 2001] ). Em todo o Brasil existe uma rede pública de hospitais-dia para o atendimento a portadores de HIV/aids, com seu funcionamento regulamentado e estimulado pelo Ministério da Saúde. Em meados de 1999 essa rede contava com 56 unidades, instaladas em serviços hospitalares e ambulatoriais, concentradas nas grandes metrópoles, onde o número de pacientes de aids é maior. Portarias ministeriais estipulam as diretrizes referentes à estrutura fisica, aos recursos humanos $\mathrm{e}$ à atribuição de funções, enquanto que o repasse de recursos financeiros para estados e municípios auxilia a efetivação da implantação desses serviços. Segundo o Ministério da Saúde: “resultados de estudos demonstraram a redução de custos da assistência prestada em HD e o crescente aumento da produtividade destes serviços." ( MS, 1999 a p. 36). 
Quanto à prática do atendimento tipo hospice, ou qualquer outra alternativa de assistência ao doente morrendo, que considere a terminalidade com especial atenção, encontram-se pouquíssimos serviços no Brasil. Segundo Figueiredo: “em 1998 [ foram identificadas ] apenas 17 unidades de cuidados paliativos em todo o território nacional, todas voltadas para a paliação de sintomas de pacientes com câncer avançado" ( Figueiredo 1999 ). Embora o tema terminalidade e morte nos hospitais seja divulgado esporadicamente na literatura médica nacional, e trabalhos investigativos importantes tenham sido realizados, raras iniciativas foram efetivadas no sentido de adequar os serviços de saúde brasileiros ao atendimento dos pacientes nessa fase. ${ }^{15}$ Ao lado do grande despreparo dos médicos e demais profissionais de saúde em nosso pais, para lidar com as necessidades do paciente em fase final, a estrutura e modo operacional dos hospitais convencionais não apresentam condições e/ou flexibilidade requeridas à realização dos cuidados dirigidos ao atendimento das necessidades desses pacientes ( Angerami-Camon 1997, Gomes e Fraga 1997 ).

Atualmente a imensa maioria dos doentes terminais morre nas enfermarias dos hospitais, submetidos a desconfortáveis regimes administrativos e terapêuticos, que os demais pacientes aceitam obedecer em troca de cura ou melhora de sua saúde ( Angerami-Camon 1997 ). Os doentes terminais, que se encontram nos hospitais para alívio de seu sofrimento, muitas vezes sequer são informados sobre sua condição de saúde, a pretexto de serem poupados de uma má notícia ( Pan Chacon et al. 1995 ). Não podem optar sobre a realização ou não de medidas de ressuscitação e procedimentos médicos invasivos em seus próprios corpos. Não recebem tratamento especializado dos profissionais de saúde, incluídos os médicos que, quase sem exceções, não receberam treinamento adequado para lidar com as necessidades originadas no processo de morrer ( Consorte 1983, Vianna e Piccelli 1998 ). Morrem longe de familiares e entes queridos; solitários em ambiente impessoal, muitas vezes submetidos a procedimentos fúteis, dolorosos ( Pessini 1990, Klafke 1991 )

\footnotetext{
${ }^{15}$ Em 1997 eram conhecidos, no Estado de São Paulo, os serviços de Cuidados Paliativos do Hospital Dr. Amaral de Carvalho, de Jaú ( SP); da Santa Casa de São Paulo; do Hospital Pérola Byington, de São Paulo; da Oncologia Clínica da PUC, de Sorocaba ( SP ); e da Faculdade de Medicina de Botucatu ( SP ) ( Figueiredo 1997 ).
} 


\title{
V - Necessidades e demandas em saúde
}

\begin{abstract}
"We have lost our way because we have defined our unlimited hopes to transcend our mortality as our needs. and we have created a medical enterprise that engineers the transformation.

At the heart of the public demand for good health is the insistence that life not be burdened with illness and that death be held at bay. That understandable desire has been rendered plausible by medical advances. Disease causes illness and death, and disease we know can be conquered." $" 16$
\end{abstract}

(Callahan 1990, p. 33 )

As necessidades de saúde de uma dada população são muitas vezes confundidas com necessidades de serviços de saúde ( Souto 1992 ). Além disso, diferentes necessidades - de saúde e de serviços - podem ser arroladas, caso se olhe da perspectiva dos profissionais de saúde, ou da perspectiva dos membros da população.

Uma interessante definição de necessidade de serviços de saúde de uma dada população, necessidade esta entendida como um juízo normativo profissional, é a de Jeffers et al. : "Aquela quantidade de serviços médicos que a opinião técnica médica acredita dever ser consumida durante um relevante periodo de tempo, para que seus membros permaneçam ou se tornem tão saudáveis quanto permitido pelo conhecimento médico existente." Neste trabalho, as referências a necessidade terão como pressuposta esta definição. Para os autores citados acima, a população apresentaria vontade ou desejo - e não necessidade - de serviços médicos, assim definidos : "Aquela quantidade de serviços médicos que seus membros sentem que devem consumir, durante um relevante periodo, baseando-se em suas próprias percepções psíquicas de suas necessidades de saúde." ( Jeffers et al. 1971, p. 46 - 47 )

\footnotetext{
${ }^{16}$ "Nós nos confundimos porque definimos as nossas ilimitadas esperanças na transcendência da mortalidade como nossa necessidade, e criamos uma empresa médica que engenha essa transformação. No centro da demanda pública por boa saúde está a insistência para que a vida não seja sobrecarregada com doenças, e que a morte seja refreada. Esse compreenstvel desejo se torna plausivel devido ao progresso médico. Doença causa sofrimento e morte, e doença, nós sabemos, pode ser subjugada."
} 
As necessidades se conformam através da percepção da falta ou carência de alguma coisa ( Schraiber e Mendes-Gonçalves 1996 ). É o desejo de suprir determinada carência que cria a necessidade. Perceber a falta de uma coisa - um bem, um estado - só é possível à medida em que se conhece a sua possibilidade de existência; a necessidade gerada depende dos valores, positivos e/ou negativos, a ela atribuídos. No caso da necessidade de saúde, a noção que se tem do estado de saúde vigente, a representação do estado de saúde ideal que se deseja alcançar, como também o conhecimento dos recursos técnicos existentes, se agregam para formá-la. Daí que o que pode ser sentido como necessidade, para um, não o é, necessariamente, para outro.

Desse modo, não deve causar estranheza o fato de que pessoas de diferentes extratos sociais, ao arrolarem as suas necessidades em saúde, construam listas diferentes. É fato bastante conhecido, entre os profissionais de saúde, que na fração mais pobre da população alguns desconfortos podem ser vividos quase que desapercebidamente, como situações constituintes da vida normal, enquanto que em outra parcela populacional os mesmos desconfortos são sentidos como extremamente desagradáveis, e encarados como situações de grande sofrimento. Isto é: a falta daquilo que nunca se experimentou - situações, condições, bens, serviços é mais dificilmente percebida.

Como exemplo: para algumas populações uma alta taxa de mortalidade infantil é parte integrante de sua história, durante várias gerações, como também a sua baixa longevidade ( índices considerados como alto e baixo, tomando-se por referência os padrões encontrados em países desenvolvidos ). Essa situação vivida institui o seu padrão de normalidade, não constituindo, para essas populações, problemas de saúde, apesar do desconforto que possa acarretar. Essas condições são, portanto, vivenciadas pela população como fatos relacionados a seu particular "modo de andar a vida" 17 . Não dão origem a uma necessidade, à medida em que sejam percebidos como uma "normalidade" inevitável.

17 Segundo Canguilhem: "Não é absurdo considerar o estado patológico como normal, na medida em que exprime uma relação com a normatividade da vida. (....) Não existe absolutamente vida sem norma de vida, e o estado mórbido é sempre uma certa maneira de viver." (Canguilhem 1982, p. $187-8$ ). 
Ao contrário, carências de outros bens ou estados - mesmo que consideradas carências de outra ordem, pelos técnicos e teóricos do campo da saúde - são às vezes tomadas como necessidades de saúde, gerando fortes demandas aos seus serviços. Exemplo disso são o desejo ou carência - expressos como necessidade - de possuir determinados atributos físicos, de controle sobre órgãos e funçð̃es orgânicas, e mesmo os chamados desejos míticos da humanidade, como a eterna juventude e a imortalidade.

Como dito anteriormente, necessidade ou carência de alguma coisa surge da falta - percebida - dessa coisa. As necessidades são, fundamentalmente, socialmente construídas e em cada tempo e lugar encontram-se necessidades diversas ${ }^{18}$.

As experiências de vida - incluidos os sofrimentos - geram representaçðes, ou percep̧ões da realidade, formuladas de acordo com o contexto sócio-cultural da população em questão ( Minayo 1994 ). Isto é, as representações ou concepções se constituem integradas à visão de mundo e conhecimento existentes, em cada grupo populacional. A idéia coletiva de um certo mal não necessariamente coincide com a visão técnica e científica do assunto em questão, e as necessidades decorrentes da vivência de uma determinada situação, podem ser interpretadas de modo diverso pela população que as sofre e pelos técnicos que as analisam. A representação social de um sofrimento sentido, portanto, não se vincula, necessariamente, à compreensão de saúde tida pelos que o sofrem.

Importante lembrar que as mesmas condições que determinam a situação de vida desfavorável à saúde, determinam, igualmente, menores possibilidades de aquisição de conhecimentos sobre o processo saúde / doença. $O$ entendimento adequado das cadeias de causação de doenças, desde os níveis de promoção de saúde e prevenção da doença até os de tratamento e reabilitação, pressupõe uma educação em saúde que as populações - e até mesmo aquelas com certo grau de escolaridade usualmente não possuem.

\footnotetext{
18 Uma análise crítica da noção de necessidades e consumo de bens na área da saúde pode ser encontrada em Oliveira: "Não existe consumo por uma necessidade objetiva de consumir. Existe prochução social de oferta e demanda dentro de um sistema de troca (....). onde a funcionalidade dos bens e das necessidades indivichuais se ajusta a posteriori, racionalizando e ao mesmo tempo recalcando estes mecanismos estruturais fundamentais." (Oliveira 1991, p. 33 ).
} 
O estabelecimento de prioridades, dentre um elenco de carências em saúde, pressupõe a compreensão de noções e conceitos cuja apreensão não é imediata. Isto é, ao se hierarquizar as necessidades em saúde segundo as carências sentidas, devem ser considerados: riscos e probabilidades, processo de adoecimento e de recuperação, relação entre custo benefício, dentre outros conceitos e noções. Esse conhecimento especifico pode ser transmitido à população leiga, em nivel suficiente para que ela possa avaliar as suas carências, mas ele não surge espontaneamente, mesmo em populações com maior preparo escolar. Isto faz com que muitas carências de um bem sejam entendidos e expressos pela população como carência de outro bem. Exemplo: parasitoses e infecções intestinais freqüentes na população infantil podem ser entendidas pelas mães como falta ou excesso de determinados alimentos e/ou de medicamentos e não como más condiçð̃es de saneamento básico.

A dificuldade de entendimento, no universo leigo, da adequada tradução das suas carências em necessidades de determinados bens e serviços, tem sido um dos motivos freqüentemente alegados pelos gestores e prestadores de serviços de saúde como inviabilizadores do diálogo entre ambos, às vezes encobrindo um real conflito de interesses (Atkinson 1993 ).

Também entre profissionais da área de saúde, nem sempre se pode encontrar consenso sobre as prioridades de saúde de uma dada população, ou sobre o estado ideal de saúde a ser tomado como meta de uma intervenção ( Charles et al 1997 ). A dificuldade para a obtenção de consenso decorre da subjetividade inerente ao julgamento de valores envolvidos nessas avaliações. De fato, quando se pode utilizar parâmetros objetivos, a avaliação torna-se mais fácil. A literatura especializada tem apresentado, recentemente, grande número de publicações sobre a necessidade de utilização de métodos objetivos e acurados para a comparação de procedimentos ( Roberts 1984, Ferguson e Keown 1995 ) e cada vez maior número de trabalhos a respeito da eficácia de determinados procedimentos e medidas, em comparação com outros. Mesmo artigos de cunho econômico, medindo a eficiência dos atos em questão, podem ser encontrados com facilidade, hoje em dia, nas revistas médicas ( Weinstein e Stason 1977, Ham 1996, Hopkins e Solomon 1996 ). 
A identificação das necessidades de saúde de uma pessoa ou de uma população requer o diagnóstico do seu estado de saúde inicial e a proposição do estado de saúde a ser atingido. A primeira dificuldade aí colocada se encontra na própria definição de saúde, de entendimento variável nos diferentes grupos culturais. A subjetividade do conceito de saúde da Organização Mundial de Saúde, bastante utilizado na literatura médica, que se refere a um bem estar percebido, de difícil mensuração, contribui para acentuar essa dificuldade.

A evolução do conhecimento científico e seu correspondente desenvolvimento tecnológico têm empurrado cada vez mais as fronteiras das possibilidades em saúde, em várias direções. Apesar de alguns consideráveis questionamentos quanto à qualidade do inegável acréscimo de longevidade obtido pelas populações de países desenvolvidos, nas últimas décadas ${ }^{19}$, é fato que as possibilidades de intervenção na saúde, no sentido de melhorá-la, vêm crescendo acentuadamente, gerando, nesse mesmo ritmo, necessidades de proporções gigantescas.

A população com acesso a informações gerais, que acompanha o desenvolver das conquistas tecnológicas, vê surgir um número infindável de recursos diagnósticos e terapêuticos para males que, até então, muitas vezes sequer imaginava poder sofrer. Daí a sentir-se carente desses recursos o passo é rápido, impulsionado pela força da mídia, sempre ávida de novidades, e do trabalho publicitário ostensivo que move o mercado dos insumos tecnológicos. As necessidades em saúde, individuais e coletivas, vão sendo criadas em ritmo maior que as possibilidades gerais de acesso a esses novos bens e serviços. A grande agilidade e globalização dos meios de comunicação atuais fazem com que, muito rapidamente, a carência sentida por alguns se transforme, através de efeito-demonstração, em necessidade sentida por muitos. Os profissionais de saúde conhecem sobejamente o aumento da demanda por um exame laboratorial, ou um medicamento, que ocorre logo após a veiculação de uma reportagem, pela televisão ou grande imprensa, exibindo histórias e

\footnotetext{
19 Alguns autores, como Gruenberg e Koizumi, propõem que o aumento de longevidade, observado recentemente em vários paises desenvolvidos, não significa melhora dos níveis de saúde mas, ao contrário, aumento da sobrevivência de pessoas doentes na população, possibilitado pelos novos recursos tecnológicos disponiveis ( Hansluwka 1987).
} 
depoimentos de pacientes satisfeitos ou até mesmo "miraculosamente salvos" por esse exame ou medicamento. $O$ despertar de novas necessidades é uma reação quase imediata aos eventos publicitários de divulgação de novos produtos.

Além da reação leiga, que pode ser desprovida - e muitas vezes é - de uma critica consistente com o conhecimento científico da Medicina, a propaganda ostensiva de novos recursos diagnósticos e terapêuticos, dirigida especificamente à clientela médica através de literatura especializada, eventos de divulgação, etc., cria entre esses profissionais a necessidade de poder contar com esses novos recursos em sua prática.

Tem-se como exemplo um fato recente: cientistas reunidos em um congresso internacional a respeito da síndrome da imunodeficiência adquirida apresentaram em uma conferência os resultados de um estudo de uso combinado de drogas para o tratamento dessa doença ( Weidle et al. 1999 ). Simultaneamente a esse comunicado científico, a grande imprensa e meios televisivos de grande parte do mundo divulgaram à população geral os achados dessa pesquisa. Imediatamente criou-se, para milhares de pessoas, a noção de que a aids, até então uma doença incurável e letal, poderia ser curada com o uso dessas drogas. Verdadeira ou não, essa noção gerou, em uma pequena fração de tempo, em milhares de pessoas, a necessidade de poder contar com essas drogas. Os doentes sentiram a necessidade de tomá-las, os médicos a necessidade de prescrevê-las, e aqueles de algum modo preocupados com o destino dos doentes ou da doença, desejaram que as necessidades das tais drogas fossem satisfeitas. Antes mesmo que fossem definidos o alcance e os limites da nova terapia proposta, necessidades prementes surgiram, em vários locais do mundo, quase que instantaneamente.

Esse fato ilustra a gênese das chamadas "necessidades sociais", como referidas por Mendes-Gonçalves: “Em qualquer caso, entretanto, será através de um amplo e multidimensional processo social que o individuo comum passará a ter como suas, gradativamente, necessidades necessárias referidas à saúde que se compõem coerentemente com as necessidades sociais e se confundem com elas, assim como verá interditadas, por ilegitimidade, aquelas necessidades necessárias que escapam a essa coerência." ( Mendes Gonçalves 1992, p. 47) 
No entanto, a geração de recursos financeiros para o custeio do setor saúde não tem se dado na mesma velocidade que a geração de necessidades. Na verdade, a distância entre ambas tem se acentuado progressivamente, deixando uma demanda insatisfeita cada vez maior. A criação de novas tecnologias, equipamentos e insumos na área da saúde consome gigantescos recursos financeiros, neste que é, atualmente, um dos maiores setores econômicos dos países modernos ( Evans e Stoddart 1990 ).

Nas economias capitalistas os investimentos realizados para a obtenção de um novo produto ou para o desenvolvimento de uma nova técnica precisam não apenas ter seu custo pago, como também gerar lucro. Ainda, a oferta de um produto qualquer no mercado - livre ou subsidiado pelo Estado - pressupõe a existência de consumidores - quer sejam estes os usuários finais, os provedores de serviços, de qualquer natureza, ou o próprio Estado - capazes de pagar pelo seu preço. Só dessa forma o mercado se estabelece e se auto alimenta, ofertando bens e serviços, gerando novas demandas.

Importante notar que a oferta e demanda de bens e serviços na área da saúde não se comporta exatamente segundo as leis gerais de mercado. Isto porque, nesse caso, existem especificidades que a tomam singular. Primeiro: entre compradores e vendedores, tanto na área privada quanto na área pública de saúde, existe sempre um intermediário, o médico, que determina, em nome do consumidor, quais os produtos que lhe são necessários. A presença do intermediário torna o mercado atípico, destituindo o consumidor final do poder de definir quais bens adquirir, e por que preço. O médico então, legitimado pelo seu conhecimento técnico, exerce o papel de representante da demanda. Segundo: os consumidores finais buscam saúde, bem estar, mas compram serviços de saúde, como meios de alcançá-los, o que leva muitas vezes a frustrações e mal entendidos. A intangibilidade da tradução do bem consumido ( serviço prestado ) em bem procurado ( melhoria da saúde ) permeia o mercado de saúde e seus serviços.

Concluindo, indicadores de mercado - como a medida da demanda por bens e serviços - não são, por si só, bons estimadores das necessidades de saúde, mesmo em países em que grande parte da população tem real poder de consumo. Mas, não obstante as especificidades da área, também no setor da saúde a oferta e procura de 
bens e serviços são mediadas pelas leis gerais de mercado e pelas preferências politicas, ou seja, pelo valor conferido a esses bens (Saltman e Figueras 1998 ).

Uma outra particularidade, em se tratando de saúde, é que a procura por serviços visa, quase invariavelmente, a recuperação do bem ( saúde ) perdido. Isto é, a demanda em saúde se dirige, fundamentalmente, aos procedimentos curativos. Excetuando-se as situações epidêmicas envolvendo doenças infecciosas, raramente a população geral demanda procedimentos preventivos com tanta força como o faz para recursos terapêuticos. A necessidade de tratamento de uma doença existente é algo muito mais intensamente percebido do que a necessidade de um procedimento qualquer que evite a aquisição de uma (im) provável doença. Daí a grande satisfação com que a população recebe a instalação de hospitais e prontos-socorros, a aquisição de ambulâncias e outros equipamentos de fins curativos, muito maior do que a satisfação demonstrada pelo recebimento de centros de saúde habilitados a realizar imunizações, exames para deteç̧ão precoce de câncer, e campanhas de orientação em saúde. Como referido em muitos textos sobre o tema, a saúde é, usualmente, mais valorizada em sua ausência.

Tomando-se como exemplo, mais uma vez, a síndrome da imunodeficiência adquirida, verifica-se que a população não doente, ou mesmo os segmentos da sociedade mais vulneráveis a ela, não se organizam para demandar as atividades preventivas necessárias ao controle da doença, ainda hoje uma enfermidade letal e estigmatizante. Por outro lado, a demanda por tratamento dos doentes com aids tem se caracterizado como um movimento reivindicatório importante, ao longo de toda história dessa epidemia. $\mathrm{E}$ as instituições governamentais têm dispensado a esses pacientes recursos diagnósticos e terapêuticos ( exames laboratoriais, medicamentos, leitos hospitalares ) nem sempre disponibilizados para outros grupos de doentes, como os portadores de hanseníase, doença de Chagas, malária.

A apreciação positiva da população a respeito de um sistema de saúde que privilegie os procedimentos curativos não deve surpreender os profissionais de saúde coletiva. No entanto, um sistema de saúde que queira fazer face aos problemas de saúde da população tem que considerar também as necessidades não percebidas, aquelas que existem sem que as pessoas estejam conscientes de sua existência. 
Para a realização do diagnóstico das necessidades de saúde de uma dada população é bastante importante levar-se em conta as necessidades sentidas, e expressas em demandas, mas sem se deixar conduzir apenas por elas; há que se fundamentar, ainda, no conhecimento técnico especializado, ou seja: no saber epidemiológico. Ou: é preciso também considerar aquelas necessidades e condições tecnicamente detectáveis, mas das quais a população não tem conhecimento, ou não valoriza adequadamente. Além disso, não se deve esquecer do sofrimento daquela parcela da população que não consegue expressar suas carências, por não saber ou não poder articulá-las.

A identificação de necessidades de saúde de uma população e a conseqüente definição de prioridades no setor saúde são atividades nas quais o conhecimento da distribuição das doenças, bem como de seus determinantes, é fundamental. A Epidemiologia, campo de conhecimento que trata dessas questões, deve fornecer as informaçð̃es necessárias para as tomadas de decisão pelas autoridades sanitárias.

No entanto, vale lembrar que ao tratar dos instrumentos adequados à identificação dos problemas de saúde de uma população, a Epidemiologia faz uso, inevitavelmente, de valores definidos socialmente. Como em qualquer outro campo de atuação, a ordenação de necessidades e de prioridades não se dá através de um método isento de uma visão ideológica da questão estudada. A construção ou a escolha de indicadores de saúde não é, como muitas vezes se diz, um procedimento "neutro". Isto é, tanto os indicadores de saúde utilizados em uma análise são impregnados de um determinado valor social, como também o são as próprias questões que esses indicadores procuram esclarecer.

Valores envolvidos na questão de saúde e doença, como os pesos atribuidos ao sofrimento humano, à perda da capacidade laborativa, à diminuição de faculdades mentais, etc., por essa ou aquela causa, de tal ou qual qualidade, são definidos socialmente. Mesmo os pesos atribuidos a eventos marcantes e singulares como a morte, são passíveis de valorização diferenciada, caso atinjam este ou aquele grupo social, em determinado momento. Identificar necessidades e, mais que isso, hierarquizá-las, requer critérios fundamentados tanto em conhecimento científico 
quanto em valores - de ordem moral e política - legitimados ou não pelo conjunto da sociedade.

O que determina que um sofrimento ou carência, sentidos por um grupo ou uma população, se transformem em um problema de saúde pública e, além disso, se transformem em objeto de uma política de saúde, é uma questão complexa. Apesar do seu papel fundamental na identificação de necessidades e prioridades em saúde, $o$ conhecimento epidemiológico, sozinho, tem alcance limitado. Daí a necessidade da contribuição de outros saberes, entre eles, da Sociologia, Política, Economia, Antropologia, História.

Segundo Nemes, não basta se ater ao "epidemiologicamente relevante", ou seja: ao "diagnóstico coletivo das doenças e condições de vida tomadas como risco de adoecer", para a escolha e proposição de uma ação programática em saúde. $\mathrm{O}$ desafio que se coloca é criar "um serviço de assistência a pessoas, com toda a diversidade de sofrimentos / condições de vida que caracterizam as necessidades de saúde." ( Nemes 1996, p. 62 ).

Definir prioridades, em um setor em que os recursos são sempre muito menores que as necessidades percebidas, não é tarefa fácil. A definição de uma certa política de saúde passa necessariamente pela avaliação das carências encontradas: sua magnitude e impacto junto à população, sua vulnerabilidade às intervenções possíveis, a efetividade e eficiência das intervenções. No campo da saúde pública, as tomadas de decisões são orientadas pelo modo de entender a determinação da saúde e da doença nas populações, e definidas por situações políticas e econômicas, internas e externas ao setor saúde.

Por isso, ao se analisar uma determinada proposta cabe tentar esclarecer qual a racionalidade que a preside, quais as necessidades que estão sendo visadas com ela, quais os grupos populacionais favorecidos, quem paga os seus custos, e, por outro lado, quais as carências e qual população que, no mesmo momento, deixam de ser atendidas.

Em um contexto global de racionamento de recursos, inclusive nos paises ricos, a responsabilidade dos formuladores das políticas e programas de saúde, que prescrevem a implantação de determinadas práticas e não de outras, é enorme, 
envolvendo o bem estar presente e mesmo a situação de saúde de geraçð̃es futuras ( New 1996; Penchas 1996 ).

Interessante notar que, no que tange às políticas governamentais, vários fatores impedem que as políticas de saúde se dirijam à resolução de problemas tecnicamente detectados. Controvérsias científicas, interesses políticos e burocráticos, "lobbies" comerciais, preferência por medidas envolvendo alta tecnologia - pelo lado dos formuladores e implementadores das políticas - e apreciação inadequada de riscos, dificuldade para modificação de estilo de vida pelo lado da população - são alguns dos obstáculos mais comumente encontrados. Daí, muitas vezes "não haver relação consistente entre o conhecimento sobre saúde e as políticas governamentais." ( Greenberg 1992, p. 531 ).

Ao contrário do que muitos profissionais de saúde - principalmente os médicos - possam pensar, a implantação de certas práticas de assistência à saúde diz respeito a toda a sociedade, incluídos aí os provedores e os usuários dos serviços. A necessidade ou não dessas práticas não deve ser resolvida apenas pelos comitês de “experts", ou como no modelo das prescrições médicas, ficar restrita ao julgamento clínico, pois é a sociedade como um todo que paga - financeira e socialmente - a conta (Roberts 1984 ).

Cabe ainda lembrar que, ao se tratar de necessidades de saúde de grupos populacionais marginalizados e sem poder de barganha, ou de temas freqüentemente excluídos das pautas de avaliação técnica e de debates gerais ( por motivos culturais, políticos, ou de outra ordem ), dificilmente se poderá contar com demanda e mecanismos de pressão para a seu atendimento. Isto é: nesses casos a demanda pode ficar encoberta, muda, não gerando pressão sobre os prestadores de serviços e/ou formuladores de políticas, a não ser excepcionalmente. No caso do atendimento aos doentes em fase terminal, a percepção da necessidade de assistência especializada pode aparecer velada, misturada a desejo de cura, ou como uma insatisfação geral com o tratamento. Por se tratar de situação vivenciada transitoriamente, dificilmente gera demanda organizada. Familiares e acompanhantes do paciente que testemunham um atendimento inadequado muitas vezes preferem esquecer, o quanto antes, todo o sofrimento passado, que mistura a perda do ente querido, vivência de 
situações afetivas e existenciais dolorosas, e a inadequação dos serviços. Por outro lado, os profissionais de saúde, que vivenciam o outro lado do atendimento, ao se reportarem a seus aprendizados obtidos nas escolas e na prática das enfermarias, certamente encontrarão o modelo dominante validado pelas instituições de ensino e pela prática tradicional, com pouca chance de percepção de necessidades não atendidas. Conforme Carapinheiro, é durante as visitas médicas nas enfermarias hospitalares que se dá a aprendizagem - social e profissional - dos internos, no processo de assimilação de modelos: "nos ardis discursivos de ocultação do saber ao doente, nas táticas de fuga e desqualificação das intervenções timidas dos doentes e até na observação e aprendizagem de como fazer a passagem furtiva pela cama do doente "de que já não há nada a fazer e a dizer" "( Carapinheiro 1993 p. 173).

Só um nível de conflito intolerável, e/ou uma maior sensibilidade à tensão gerada, poderá causar a percepção e o acolhimento de outras necessidades. Quanto à população geral, que em grande parte um dia viverá a terminalidade - salvos os que viverem a morte repentina, ou não anunciada - não se espera que demandará uma melhor assistência ao processo de morrer, enquanto tratá-la como uma questão inexistente. ${ }^{20}$

\footnotetext{
${ }^{20}$ Como diz Baldessin: "Na cultura ocidental é caracteristico que a morte seja excluida dos nossos pensamentos pelo tempo mais longo possivel. [ ] Queremos que nada nos lembre a morte e o morrer. Como crianças, acreditamos poder excluir a morte de forma mágica se näo falarmos nela." (Baldessin 1996, p. 497).
} 


\title{
VI - Qualidade das práticas de saúde
}

\begin{abstract}
"O motivo para o conceito de qualidade ser tão facilmente convertido em uma norma de conchuta é que ele tem por base intersubjetiva um juizo, mais precisamente um juizo das pessoas sobre o que é bom no círculo da produção / consumo. [ ... I tal juizo realiza-se fundado em crenças (ou conceitos) previamente existentes do lado do produtor e do lado do consumidor, crenças fornecidas pela tradição cultural, pela tecnologia, pelas doutrinas da gerência, pelos valores morais vigentes, etc.. "
\end{abstract}

(Nogueira 1995, p. 38 )

A qualidade das práticas de saúde, tema cada vez mais valorizado nos últimos anos, pode ser avaliada tanto em função das características da estrutura assistencial envolvida, como do processo ( o atendimento em si ) ou em função do resultado obtido ( o estado de saúde ) (Donabedian 1988 ).

A comparação entre diversos procedimentos, em busca de melhor relação custo-benefício, medida em termos de custo-efetividade, ou custo-eficácia, ou de qualquer outro modo, sejam os custos de ordem financeira ou não, torna necessária a mensuração dos resultados ( benefício ) obtidos. No caso da saúde, alguns resultados tradicionalmente utilizados - como sobrevida - têm uso bastante restrito, uma vez que só traz informações consideráveis quando aplicado àquelas intervenções que têm por objetivo postergar a morte. Ainda assim, trata-se de um dado parcial, uma vez que apenas quantifica os anos de vida creditados ao procedimento em questão, sem fazer referência ao estado de saúde do paciente. Exemplificando: para um dado paciente, cinco anos de vida saudável, sem seqüelas, após o tratamento cirúrgico de um tumor maligno é uma situação melhor, igual ou pior que seis anos de sobrevida com dor e limitaçð̃es, em decorrência da realização do procedimento alternativo? Essas duas situaçð̃es são comparáveis? ( Yin et al. 1995).

Os avanços tecnológicos da Medicina trazem, ininterruptamente, múltiplas possibilidades diagnósticas e terapêuticas, com custos variados, tornando cada vez mais difícil a escolha do instrumental a ser utilizado em cada situação. Estudos analisando resultados de procedimentos, em grupos comparáveis entre si, tornaram- 
se obrigatórios para as tomadas de decisão. Por isso, estudos complexos, envolvendo a clínica, a epidemiologia, a economia, a estatística e outras áreas do conhecimento, vêm tentando dar conta de comparar os resultados dos diversos procedimentos, em termos de estado de saúde alcançado, valorizando simultaneamente a quantidade ( $o$ tempo ) e a qualidade de vida obtidos ${ }^{21}$ (Kerridge et al. 1995, Yin et al. 1995 ).

A avaliação da qualidade de vida não consegue livrar-se das mesmas dificuldades encontradas na mensuração do estado de saúde, apesar dos muitos esforços para contorná-las. Alguns métodos propostos servem mais a determinadas situações que a outras, mas todos são mais ou menos limitados pelo subjetivismo das avaliações, o que dificulta a comparação de resultados entre populações de culturas diferentes. Porém, inegavelmente, adicionam informações à simples quantificação de anos de sobrevida.

Mesmo assim as escolhas são mais dificeis do que alguns estudos que se propð̃em a quantificar a relação custo-benefício parecem sugerir. A avaliação dos recursos necessários à assistência a doentes seriamente debilitados, como os dependentes de materiais/equipamentos ( quimioterapia, diálise ) e/ou de supervisão constante de profissionais especializados, como certos deficientes fisicos e mentais, poderá levar à não contemplação desses grupos - no processo decisório de alocação de recursos em que suas necessidades sejam confrontadas com as dos pacientes que se beneficiam mais com menos recursos - e outra ordem de considerações terá que ser levada em conta, para que se possa atendê-los (Evens 1995 ).

Ainda, considerando-se a análise de resultados, alguns estudos limitam-se a comparar situações específicas, incidentes após a intervenção em questão, como taxas de complicaçð̃es, retorno de sintomas ou reincidências ( Azevedo 1992 ). Essa estratégia facilita a comparação entre diversos procedimentos, mas deve-se lembrar, na interpretação dos resultados, que ela apresenta uma visão parcial, fragmentada, da situação final do paciente, isto é, não leva em conta a qualidade de vida acarretada por cada um dos procedimentos analisados.

\footnotetext{
${ }^{21}$ Um método bastante divulgado recentemente é o chamado Quality-Adjusted Life-Years ( QALYs ), que utiliza um esquema de ponderação - valor variável de 0 a 1 , atribuível ao estado de saúde - para cada ano de sobrevida. A soma dos pontos obtidos resultará em um número dependente tanto do tempo como da qualidade de sobrevida do paciente. (Kerridge et al. 1995, Yin et al. 1995)
} 
Quanto à qualidade do processo, isto é, o nivel de adequação e modo de realização do atendimento, independentemente do resultado obtido, também há que se considerar certo grau de subjetividade sempre presente nessa avaliação, talvez maior que na avaliação de resultados.

De fato, ao avaliar a qualidade do atendimento, os profissionais de saúde tanto fazem uso de um referencial técnico, aparentemente objetivo, dependente do conhecimento e tecnologia disponíveis no momento, quanto outro referencial, subjetivo. Este é o que os habilita ao julgamento da situação particular e que, principalmente os médicos, referem como "a arte da Medicina". Isto é, para os próprios médicos, a prática da Medicina seria a arte de aplicar a ciência para cada caso em particular ( Schraiber 1993 ).

Devido à dificuldade de se padronizar procedimentos em Medicina ou, em outras palavras, à constante necessidade de tratamentos individualizados ${ }^{22}$, muitos profissionais dessa área acham bastante dificil, senão impossível, o estabelecimento de critérios padronizados para a avaliação de condutas médicas. Esse pensamento tem inviabilizado algumas propostas de adaptação de programas de controle de qualidade importados de outras áreas, como por exemplo o do chamado programa de Controle de Qualidade Total, originado na área empresarial. Entre as objeções a esse método, comumente mencionadas, encontram-se: a pequena competitividade do mercado de serviços de saúde, a grande variabilidade dos produtos e serviços oferecidos nos hospitais, a heterogeneidade de agentes que produzem os serviços de saúde, a falta de condições dos usuários ( consumidores ) dos serviços para avaliá-los adequadamente ( Nogueira 1994 ).

A insuficiente capacidade técnica dos usuários dos serviços para julgar a adequação e qualidade da assistência recebida é vista de um modo ambivalente por parte dos profissionais médicos. Estes asseguram para si a primazia das escolhas qual procedimento diagnóstico realizar, qual conduta terapêutica seguir - em nome de seu conhecimento técnico especializado, ao mesmo tempo em que se queixam da

\footnotetext{
22 De fato, um dos princípios da prática clínica pode ser resumido na máxima: "Cada caso é um caso." ( Schraiber 1993 ). E uma frase bastante comum nos hospitais e serviços médicos afirma: "A Clínica é soberana." ( por referência ao conhecimento teórico, generalizador ).
} 
ignorância dos pacientes para avaliar corretamente as suas recomendações e seus acertos ( Atkinson 1993 ). Ao reter para si o monopólio do saber referente às práticas diagnósticas e terapêuticas, os médicos estariam tratando de resguardar a sua autonomia de ação, autonomia essa tão cara a esses profissionais, cada vez mais ameaçada pela crescente incorporação das tecnologias modernas, que tendem a reduzir o componente de "arte" do ato médico ( Schraiber 1993 ). O fato de os usuários dos serviços de saúde serem compelidos a utilizar um intermediário - quase invariavelmente o médico - para o consumo e avaliação desses mesmos serviços, traz um importante desvio nessa avaliação. Uma vez desprovidos da legitimidade conferida pelo saber técnico - que eles não possuem - resta aos usuários dos serviços confiar na intermediação dos profissionais que são, ao mesmo tempo, os provedores e avaliadores dos serviços em questão.

Por isso, muitos estudos de avaliação dos serviços, da perspectiva dos usuários, se abstêm de falar em qualidade desses serviços e tratam da medida da satisfação do usuário.

A qualidade do atendimento, tal como percebida pelos usuários dos serviços, também se relaciona ao grau de conhecimento técnico possuído, mas depende fundamentalmente das expectativas que eles têm dos serviços buscados, dependendo grandemente do grau de cidadania e experiências de vida da população em questão, como referido anteriormente.

Como as expectativas são produzidas histórica e socialmente, elas se atrelam às alternativas concretamente disponíveis à clientela investigada. Isto é, elas seguem a mesma lógica do sistema vigente, sendo impostas por ele (Oliveira 1991 ). As expectativas estão sempre aquém do desejo, das possibilidades latentes, da utopia.

Alguns estudos, no entanto, têm evidenciado que a satisfação do usuário com os serviços de saúde se associa fortemente a características do processo, até mais que aos resultados obtidos ( Hammermeister et al. 1995 ). Assim: a importância dada pelos usuários à qualidade das relações interpessoais durante o atendimento ( Cohn et al. 1991 ). De fato, a natureza do atendimento em saúde, que envolve a motivação do paciente para aceitar o tratamento instituído pelo profissional, implica em um peso 
importante atribuível à relação humana, muitas vezes um dos fatores determinantes do resultado obtido ( Hart e Dieppe 1996, Atkinson 1993 ). Uma pesquisa aprofundada a respeito das altas taxas de satisfação do usuário com os serviços recebidos, feita na Inglaterra, revelou, ao final, uma avaliação negativa dos mesmos serviços; isto é: os pacientes se diziam satisfeitos com os serviços, ao mesmo tempo em que relataram experiências negativas importantes, escondidas no levantamento geral, mostrando a complexidade dessa questão (Williams et al. 1998 ).

O importante a ser retido sobre este tema é a multiplicidade de fatores que devem ser contemplados, ao se estudar a qualidade das práticas de saúde, mormente quando se pretende compará-las entre si. 


\title{
VII - Assistência aos doentes em fase terminal: breve histórico
}

\begin{abstract}
"The more recent development in attitudes to death is the increase in importance of the role of the medical profession. Up to the $18^{\text {th }}$ century, their role had been more or less to assist in the course of nature, to promote healing or help the coming of an easy and speedy death. [...] However, within the space of half-a-century the doctors power was seen to have grown to challenge death. From this time onwards the image of death has become dissected into a host of identifiable specific diseases over which the doctors were seen to have increasing control." 23
\end{abstract}

( Shanley 1982, p. 1362 )

Desde os tempos mais remotos a humanidade tem se preocupado com os cuidados às pessoas enfermas e moribundas. Historiografias e análises sociológicas do tema relatam as práticas realizadas, bem como os dilemas éticos a elas associados, da antigüidade aos tempos modernos. $\mathrm{O}$ respeito ao paciente e a máxima da beneficência, claramente expressos no conhecido juramento de Hipócrates, têm sido característicos de quase todos os períodos da história da Medicina, apesar das diferentes conceituações possiveis do que seja essa beneficência (Cowley et al. 1992 ). A perspectiva histórica pode nos ajudar a compreender alguns de nossos questionamentos atuais.

As civilizações grega e romana antigas, bases da cultura ocidental, tinham como característica o respeito à vida. A tecnologia médica disponível à época não permitia quaisquer pretensões de deter o curso da morte, aceita como decorrência natural da vida. A morte não era tão temida e a vida não era tão longa como nos dias de hoje. Havia grande sensibilidade a temas como justiça, autonomia, beneficência e qualidade de vida, embora não definidos nesses termos ( Cowley et al. 1992 ). As questões fundamentais relacionadas à vida e à morte que ainda hoje debatemos

23 "O mais recente desenvolvimento das atitudes perante a morte é a crescente importância do papel da profissão médica. Até o século 18 esse papel tinha sido mais ou menos assistir ao curso da natureza, promovendo a cura ou ajudando a chegada de uma morte fácil e rápida. [ ... J Contudo, no espaço de meio século, viu-se o poder do médico crescer em desafio à morte. Dessa época em diante a imagem da morte se tornou dissecada em hospedeira de doenças especificas conhecidas, sobre as quais se vê os médicos tendo controle cada vez maior." 
foram primeiramente articuladas pelos filósofos e cientistas da época. Seus escritos expressam preocupações com a ética e a prática da Medicina, da mesma forma que os encontrados na literatura moderna.

No que diz respeito ao cuidado com os doentes em fase terminal, havia ampla aceitação da necessidade de se limitar o tratamento dos casos sem esperança de cura. Uma vez que a vida saudável e produtiva era bastante valorizada, a morte era encarada como decorrência natural de uma doença ou acidente graves, sem que se intentasse prolongar uma vida sem qualidade. Para os estóicos e hedonistas a morte também podia ser uma opção válida para aqueles que, vivendo uma situação qualquer desfavorável, a escolhessem; para outros pensadores da época - Aristóteles, Pitágoras - o suicídio era encarado como covardia. O papel dos médicos, os artesões da cura, no apressamento da morte dos sofredores incuráveis era alvo de ativos debates, e as práticas da época bastante diversificadas ( Cowley et al. 1992 ).

A ascensão do cristianismo, na Idade Média, pôs fím a esses debates, afirmando a santidade da vida e a competência divina exclusiva nas decisões sobre a vida e a morte de qualquer criatura humana. $O$ cristianismo estimulou seus fiéis a cuidar dos doentes: nos tempos medievais muitas ordens religiosas cristãs assumiram o amparo aos enfermos sem moradia e desenvolveram técnicas de cura em seus mosteiros. A caridade cristã era a propulsora dos cuidados aos doentes, os monges eram tão procurados como os médicos para ministrar remédios (Antunes 1991 ). Data dessa época o surgimento dos hospitais, como locais de acolhimento de doentes pobres e moribundos, de viajantes de passagem, mormente aqueles em peregrinação às terras santas, e de desafortunados de todos os gêneros, já que os doentes abastados eram cuidados em suas casas, pelos médicos que os iam visitar. Atender aos agonizantes revestia-se de especial importância religiosa. A preferência da população pelos padres e não pelos médicos - tidos como não muito confiáveis - se justificava também pelos parcos recursos médicos disponíveis nessa época ( Cowley et al. 1992 ). Os tratamentos visavam aliviar as dores do corpo e do espírito, com tisanas e sacramentos (Antunes 1991 ).

As pragas e epidemias, comuns no final da Idade Média, trouxeram a morte como tragédia coletiva, revestindo-a de características macabras. Um tratado 
específico foi escrito: "Ars Moriendi", com a finalidade de guiar os moribundos em sua despedida da vida. A morte passou então a ser temida, como um momento especial de inquietações espirituais, envolvida em sofrimento e perigo. A arte produzida no período atesta esse novo enfoque, com imagens assustadoras e literatura de edificação da agonia ( Ariès 1990).

$\mathrm{O}$ ressurgimento do interesse pelos conhecimentos clássicos - gregos e romanos - bem como a fundação de universidades e bibliotecas ocorridos no período seguinte, o Renascimento, mudou o enfoque dos questionamentos sobre a morte e o morrer, subtraindo-lhes, gradualmente, o caráter religioso. Progressivamente, a morte foi deixando de ser encarada como um confronto espiritual entre o bem e o mal, passando a fazer parte dos riscos diários da vida mundana. Os cuidados com os agonizantes eram desempenhados pela família ou, nos casos dos pobres e destituídos de quem os cuidasse, pelos praticantes de caridade. Caso o doente tivesse posses, os médicos eram chamados ao leito, para aliviar sofrimentos ou confirmar o estado terminal, mas não para adiar ou adiantar a morte. No Renascimento a Medicina se imbuiu de um espírito novo, otimista. Ela progrediu e se profissionalizou: licenciou seus membros, produziu códigos éticos. A moral cristã e os princípios Hipocráticos ainda eram fielmente seguidos, embora alguns renomados pensadores da época, como Francis Bacon e Thomas More tivessem advogado o apressamento da morte em situações de sofrimento incontrolável e doença incurável. Bacon foi um dos precursores da idéia de eutanásia como atitude médica, embora também tenha sido entusiasta defensor do prolongamento da vida devido ao aumento da longevidade humana, que ele acreditava não só possível como desejável ( Cowley et al. 1992 ).

No período seguinte, Iluminismo, o desenvolvimento da moderna medicina, sob a inspiração do positivismo, recolocou definitivamente o debate sobre a morte e o morrer na esfera da ciência e não mais na da religião. As preocupações espirituais foram sendo esquecidas e logo se substituiu o padre pelo médico, a beira do leito do agonizante. A morte - e não a má saúde - é encarada como o inimigo da vida e a resistência a ela (à morte ) passou a ser característica dos tratamentos médicos. Os recursos terapêuticos existentes permitiam algum controle da dor, sem no entanto poder propiciar qualquer prolongamento artificial da vida, o que marcou a 
assistência médica aos agonizantes, nesse época, como um conjunto de práticas de alívio do sofrimento fisico, sem maiores dilemas éticos. A morte desaparece dos tratados médicos e a Medicina se reafirma como defensora da vida (Cowley et al. 1992). A organização social do período faz com que a morte seja tratada de maneira diversa segundo a classe social do moribundo: simples e discreta nos meios populares, pomposa e retórica nos meios burgueses. A morte solitária ou repentina é temida por todos, morrer rodeado por familiares e amigos é uma satisfação. A morte de uma pessoa afetava todo o seu grupo social, do adoecimento ao período de luto: o funeral, os serviços religiosos eram acontecimentos públicos, e o luto social servia para reatar os laços da comunidade e consolidar a unidade do grupo (Ariès 1990 ).

No final do século XIX surge uma nova concepção de doença: o mal crônico, e se atribui ao médico um novo poder - o de tratar doenças específicas - e também um novo status social. A partir dessa época a assistência médica aos doentes graves passa a ser uma necessidade das classes abastadas. Segundo Illich, poder desfrutar de tratamento médico vira apanágio de uma classe social, modismo entre os jovens ricos e esnobes; os idosos de posses recusam-se a morrer ( Ilich 1975).

Os sensíveis progressos alcançados pela Medicina já no início do século XX reafirmam seu papel junto aos doentes graves: ela é capaz de curar doenças, aliviar sofrimentos e também prolongar a vida. A tecnologia médica disponivel no primeiro periodo pós-guerra já habilita os médicos a realizarem tratamentos mais complexos, mas o uso crescente de equipamentos impossibilita a realização de uma completa assistência nos domicílios. Aos poucos, a partir dos anos 30, os doentes graves e agonizantes passam a ser tratados nos hospitais, o que vem a se tornar prática generalizada nos anos 50 (Ariès 1990 ).

As sociedades modernas acreditam que a vida longa e saudável pode ser obtida através da assistência médica. Ao assumirem a responsabilidade pela saúde e prevenção da morte de seus membros, a assistência médica passa a ser praticamente exigida por elas. $O$ hospital torna-se então o lugar da cura e também da morte prevista, o cenário aceito pelo pessoal médico e pela sociedade para o tratamento dos doentes. É para o hospital que as famílias levam seus enfermos graves para obter assistência: quer seja tratamento e cura das moléstias ou alívio do sofrimento nos 
instantes finais, quando não há possibilidade de cura. Gradualmente, os cidadãos das sociedades ocidentais modernas passam a assumir como necessidade a assistência hospitalar ao doente moribundo: os que não têm esse direito assegurado são tidos como carentes desse recurso, principalmente nas grandes cidades ( Illich 1975 ).

Nos hospitais não é mais o paciente, mas o regulamento institucional que coordena o processo de morrer que, por isso mesmo, sofre uma transformação radical. A imposição das regras hospitalares sobre os pacientes é estressante, tanto para os doentes em processo de cura, como de morte. Tanto uns como outros, todos os pacientes internados deverão abandonar seus hábitos e rotinas usuais e assumir os hábitos e rotinas hospitalares, incluindo mesmo os mais intimos, que lhe conferem identidade. $O$ paciente agonizante não decide sobre como se disporá de seu corpo, mas sim, o médico toma as decisões. $O$ doente também não mais tem poder decisório sobre o uso do seu tempo, e pouco pode fazer pela resolução dos assuntos pendentes que the provoquem angústia ou ansiedade. Os regulamentos hospitalares definem as visitas que lhe são permitidas, e seus parcos momentos; regem a realização das mínimas atividades, como andar, tomar banho, vestir-se, comer, dormir. Restringem a alimentação, o fumo, a bebida; confiscam roupas pessoais, objetos. Até mesmo a avaliação de seu sofrimento - suas dores, seu estado - não mais pertence ao doente: o discurso médico, o único válido no ambiente hospitalar, expropria-lhe, muitas vezes, também a voz (Lepargneur 1987 ). A hospitalização tira o paciente do seu ambiente familiar, quebra sua rotina e seu status anterior, traz desconforto e insegurança. Mais que isso: impõe, simultaneamente, solidão e falta de privacidade; confina e aliena o doente de sua morte ( Marín e Llorenz 1997 ).

Não obstante, a hospitalização do moribundo é vista como necessária, nas sociedades modernas. A assistência médica pode realizar milagres, e negá-la pode ser visto/sentido como abandono do doente ( McCue 1995 ). Essa mudança no modo de morrer, verificada nas sociedades ocidentais industrializadas a partir de meados deste último século, não se deu apenas devido à maior efetividade da Medicina no controle das doenças. A conjunção desse fator com as demais mudanças sociais decorrentes da nova organização da vida cotidiana - determinada em última instância pela conjuntura econômica e social - é que traçou esses rumos. 
De fato, a falta de suporte social e das condições necessárias à realização dos cuidados básicos do doente em sua casa, característicos dos tempos modernos, dificultam muito ou inviabilizam a assistência aos agonizantes em seus domicílios, principalmente nas grandes cidades. Entre outros fatores, contribuíram para banir a morte das residências: o não mais poder-se contar com a disponibilidade de familiares, amigos e/ou vizinhança solidários para auxiliar na prestação de cuidados ao doente e nos procedimentos após a morte; as moradias pouco espaçosas, em apartamentos dotados de escadarias e/ou pequenos elevadores que dificultam a realização de velórios e o translado de caixões; a dificuldade de locomoção dos médicos - para medicar e atestar o óbito ( Illich 1975, Ariès 1990 ). Pressões de ordem econômica também favorecem o encaminhamento dos pacientes terminais aos hospitais: os familiares do doente precisam trabalhar; os seguros de saúde públicos $\mathrm{e}$ privados dos países desenvolvidos garantem o reembolso das despesas hospitalares, mas nem sempre o das despesas realizadas em tratamentos domiciliares ( Illich 1975 ).

Gradualmente, a sociedade moderna foi se distanciando das velhas práticas de assistência aos agonizantes. A morte e o morrer foram ficando cada vez mais restritos aos ambientes hospitalares, onde também não são vistos com naturalidade. Encarada como falha, insucesso, também no hospital a morte é quase sempre um acontecimento indesejável. Em outras palavras: se o domicílio não é mais o local adequado ao acolhimento do moribundo, o hospital de hoje também não é ( Alvarez et al. 1997 ). A morte no hospital é muitas vezes vista como derrota ou, pior ainda, como sinalizadora de um erro ou fracasso médico. As rotinas hospitalares tentam escondêla. Para Illich, a morte é escamoteada nos hospitais ( Illich 1975 p. 159 - 188 ). Usam-se eufemismos: a morte é chamada de parada cardíaca, ou êxito letal, e o doente não morre, mas sim, não responde ao tratamento ( Corr 1995 ). Usam-se procedimentos estratégicos para ocultá-la, como: portas fechadas, biombos, retirada rápida e camuflada dos corpos das enfermarias, afastamento de familiares chorosos, morgues e necrotérios escondidos nos sub-solos ( Louzã e Louzã Neto 1982, Lessa 1995 ). Enfim, também nos hospitais, para onde foi deslocada, a morte é um assunto tabu, nos dias de hoje ( Ariés 1990, Kübler-Ross 1998 ). Na cultura médica atual a morte é a grande inimiga a ser dominada ( Callahan 1995, 2000 ). 
As inegáveis conquistas da tecnologia médica encontram seus limites nos pacientes que parecem “insistir em morrer”, apesar delas. As vitórias contra a morte, mesmo que transitórias, fortalecem o prestígio da Medicina $\mathrm{O}$ mito da imortalidade, alimentado pela eficácia da Medicina moderna, encontra seus maiores suportes nos salvamentos heróicos realizados nas unidades de terapia intensiva, nas recuperações quase que impossíveis, viabilizadas pelas novas conquistas tecnológicas. Evitar a morte a qualquer custo, através de procedimentos agressivos e invasivos tornou-se habitual e quase que invariavelmente obrigatório nos hospitais mais ricos de recursos técnicos e financeiros ( Wlody 1995 ). Sem dúvida, através desses recursos ressuscitação, respiração artificial, marca-passos cardíacos, alimentação parenteral, etc. - a morte pode ser postergada com sucesso em muitos casos, possibilitando tanto a completa recuperação do paciente como também a manutenção da vida vegetativa de pacientes comatosos, por anos a fio.

Surgem então os dilemas éticos de nossa era. Questões relacionadas à indicação e aos limites das medidas de prolongamento artificial da vida humana passam a fazer parte do cotidiano médico nos hospitais modernos. Até quando e a que custos - financeiros e sociais - se deve investir nesse processo; e qual qualidade de vida se deve aceitar, são algumas das questões que são debatidas com grande freqũência nas conferências e publicações médicas. Surgem novas expressões, como obstinação terapêutica: evitar a morte a qualquer custo, com qualquer resultado (Abiven 1999 ), futilidade médica: de dificil definição, seria o tratamento que não traz beneficio ao paciente ( Jecker 1995, Youngner 1995 ), distanásia: morte com muito sofrimento ( Pessini 1996 ), e candentes debates na literatura especializada.

Em paises desenvolvidos a sociedade tem se envolvido com essas questões, principalmente naqueles onde $\mathrm{o}$ avanço e domínio tecnológicos se deram de modo mais intensivo, comprometendo a qualidade de vida dos pacientes e de seus familiares. Como já referido, é nos Estados Unidos da América que surgiram com grande força os movimentos de resgate da autonomia do moribundo sobre seu processo de morte ( "Right-to Die"), e de valorização da qualidade de vida restante aos doentes sem possibilidades de cura. Estudos enfocando aspectos relacionados à morte e ao morrer, publicados nesse país nos anos 60 , deram grande destaque a esse 
tema, não apenas entre os profissionais das áreas abordadas, mas também entre a população geral. São eles: o estudo de Mitford sobre os excessos da exploração comercial da indústria funerária americana, publicado em 1963; as pesquisas de Glaser e Strauss sobre as dificuldades dos profissionais de saúde para tratar dos moribundos, e finalmente, mas de grande impacto, o livro de Kübler-Ross sobre o processo de morrer ${ }^{24}$ A divulgação ampla desses estudos através da grande imprensa gerou intenso envolvimento popular nos debates, em um clima já favorável a questionamentos, como já referido ( Paradis e Cummings 1986, Copp 1998 ).

Lideradas por leigos movidos por uma indignação contra o modelo médico vigente de assistência aos doentes agonizantes, começam a surgir no final dos anos 60, nos Estados Unidos da América, algumas experiências de tratamento domiciliar aos doentes terminais. Pequenos grupos juntavam-se em associações filantrópicas, a maioria delas religiosa, e ofereciam aos doentes e familiares o atendimento possível, assumindo a realização dos cuidados básicos ao doente e oferecendo apoio social, emocional e espiritual a ele e seus familiares. A rejeição original ao trabalho de profissionais e a ênfase no caráter voluntário da prestação de serviços levaram, inicialmente, a alguma inadequação e ineficácia, principalmente no que se refere ao controle da dor e outros sintomas dos pacientes. Logo, portanto, se verificou a necessidade do envolvimento de profissionais de saúde para a prescrição e manejo de medicamentos. Avessos ao autoritarismo médico e adeptos de uma concepção multidimensional de saúde, alguns grupos buscaram, inicialmente, o auxílio de terapias alternativas ( acupuntura, técnicas de massagem e relaxamento ), para o tratamento dos sintomas indesejáveis ( Abel 1986, MacCormack 1994 ).

Poucos anos antes desse movimento americano, a assistência aos doentes agonizantes na Inglaterra também começava a ser alvo de atenção, ao menos por parte de uma profissional de saúde muito especial. Desde há várias décadas já existiam nesse pais instituições hospitalares destinadas a prover cuidados de

\footnotetext{
${ }^{24}$ Mitford JÁ. The American Way of Death. New York:Fawcett Crest, 1963. Glaser BG and Strauss A. Awareness of Dying. Chicago: Aldine, 1965. Glaser BG and Strauss A. Time for Dying. Chicago: Aldine, 1968. Kubler-Ross E. On Death and Dying. New York: Macmillan, 1969.
} 
enfermagem e medicação paliativa aos moribundos, chamadas hospices. ${ }^{25}$ Esses hospices caracterizavam-se por precária assistência médica. Sensibilizada com a alta prevalência de dor e desconforto entre os doentes, uma enfermeira e assistente social, Cicely Saunders ( mais tarde agraciada com o título de "Dame"), decidiu fazer algo para melhorar esse quadro. Estudou Medicina, dedicou-se a ouvir e examinar esses pacientes, e fez pesquisas sobre dor e demais sintomas. Durante sete anos de estágio como médica no St. Joseph's Hospice em Londres, ela analisou a experiência dolorosa de mais de 1100 pacientes, tratando-os com recursos farmacológicos eficazes juntamente com apoio psicossocial e espiritual. Em 1963 a Dra. Saunders visitou o Yale-New Haven Medical Center, nos Estados Unidos da América, onde compartilhou suas experiências bem sucedidas de alívio da dor. Em 1967 ela fundou o primeiro hospice moderno na Inglaterra, o St. Christopher's, instituição que veio a ser modelo de assistência, ensino e pesquisa no cuidado aos pacientes morrendo e a suas famílias (Amenta 1985, Saunders 1991, Clark 1997 ).

$O$ intercâmbio entre o movimento social americano e a experiência inglesa liderada pela Dra. Saunders foi fértil. Sob a inspiração do modelo inglês e dos novos conhecimentos sobre o processo de morrer recentemente publicados, o primeiro hospice americano: o Connecticut Hospice foi fundado em New Haven, em 1974. À essa época alguns conceitos já apareciam consolidados e claros, na busca do conforto do doente em seu processo de morte: a necessidade da colaboração de uma equipe multidisciplinar para proporcionar assistência integral, a importância de ouvir o doente falar de suas necessidades, e de tratar a dor e outros sintomas com drogas eficazes, e também o tratamento da familia juntamente com o paciente (Amenta 1985 ).

A eficácia no controle da dor, conquistada através da experiência da Dra. Saunders e a atuação de voluntários na prestação de serviços a pacientes e familiares, característica do modelo original americano, fortaleceram a assistência domiciliar aos pacientes, modalidade não prevista inicialmente no modelo inglês, e assimilado

${ }^{25}$ Em meados do século XIX, uma freira católica irlandesa, Sister Mary Aikenhead, contemporânea de Florence Nightingale, abriu em Dublim uma casa para alojar pacientes em fase terminal, e chamou-a de Hospice, por analogia às hospedarias para o descanso dos viajantes, na Idade Média. Sob sua liderança a sua ordem religiosa - Irish Sisters of Charity - implantou vários desses estabelecimentos na Irlanda e também na Inglaterra. O primeiro Hospice inglês, o St. Joseph's foi fundado em 1905 (Paradis 1985). 
posteriormente. A origem contra-institucional do modelo americano preconizava essa forma de atendimento. O modelo hospice de assistência aos pacientes morrendo passou então a ser conhecido mais como um conceito ou filosofia do que um local de atendimento. $\mathrm{O}$ apoio integral constituiu-se uma sua característica fundamental.

O novo modelo de atendimento a doentes em fase terminal não tardou a se espalhar nos Estados Unidos da América, com seus diversos modos de operação, combinando internação de pacientes em unidade própria ( os hospices propriamente ditos ) ou em enfermaria de hospital geral, e o atendimento domiciliar. A sua aceitação, por parte dos usuários dos serviços e da população geral, como também pelos profissionais de saúde, foi grande. Em 1978 foi fundada a National Hospice Organization ( N.H.O.), associação que congregava, já nesse ano, mais de 200 estabelecimentos prestadores de serviços de hospice, em todo o país. Seus objetivos eram: criar diretrizes e padrões para o estabelecimento e operação dos hospices, promover treinamentos, advogar os interesses dos seus associados ( Beresford e Connor 1999 ). Em 1983 foi sancionada uma lei regulamentando o reembolso dos custos dos serviços de hospice pelo sistema federal de seguro saúde americano ( Medicare e Medicaid ). Esse ato governamental propiciou suporte financeiro a centenas de pequenas organizações que, até então, sobreviviam praticamente de doações. Logo a seguir, grandes empresas privadas de seguros de saúde ( Blue Cross, Blue Shields ) passaram a oferecer atendimento tipo hospice entre seus serviços. A ampliação da rede desses serviços em todo o país foi acentuada, em suas várias modalidades ( só pacientes internados, só atendimento domiciliar, ambas as modalidades ). A entrada de empresas privadas na operação dos hospices, pouco depois, acabou por descaracterizar o modelo não lucrativo inicial (Amenta 1985, Abel 1986).

$\mathrm{O}$ ideário inicial do movimento hospice americano, que segundo autores como Abel, estava calcado numa visão romântica do potencial humano, pretendia não apenas diminuir o sofrimento causado pela morte, mas também restituir autonomia e dignidade ao paciente e transformar o evento da morte em um momento de crescimento e significado para todos que dele participassem ( Abel 1986 ). Embora ainda bastante divulgada em todo o país, essa proposta ideal foi perdendo um pouco de sua força à medida que os hospices passaram a ser integrados às instituições de 
saúde dominantes. A incorporação da assistência hospice à rede de prestação de serviços oficial do sistema de saúde, nos Estados Unidos da América, foi rápida. Ela foi impulsionada pelos benefícios financeiros e administrativos trazidos pela união com o sistema formal, como: obtenção das licenças e certificados necessários ao funcionamento dos serviços, maior racionalidade na alocação de recursos, facilitação do reembolso dos seguros, etc.. As lideranças do movimento viam com bons olhos essa integração, esperando que o atendimento nos hospices pudesse servir como exemplo de humanização da assistência para os serviços de saúde convencionais. Além disso, a integração dos hospices no sistema de saúde oficial sem dúvida facilitou o encaminhamento a eles dos pacientes atendidos em instituições médicas tradicionais. No entanto, não se pode negar que nesse processo de integração, a sua independência e seus valores ficaram ameaçados ( Abel 1986 ).

Hoje o hospice encontra-se totalmente integrado no sistema formal de saúde americano. A sua maior influência sobre a assistência convencional tem sido o controle da dor física, cujo desenvolvimento se deu em grande proporção nesses serviços, embora o conceito hospice de assistência enfatize o alívio da "dor total" física, mental, social e espiritual ( Rhymes 1990 ). Apesar da grande diversidade de serviços existentes, em termos de capacidade, orçamento e modelos operacionais, ainda mantém suas características básicas. São elas: assistência psíquica, social e espiritual; alívio dos sintomas físicos, principalmente dor, com manutenção, sempre que possível do estado de consciência do paciente; trabalho integrado de equipe multiprofissional; atenção ininterrupta ( 24 horas/dia, sete dias/semana ); prestação de cuidados contínuos, isto é, em qualquer regime de atendimento; não acelerar nem retardar o processo da morte; foco dos cuidados na família, e não apenas no paciente, incluindo assistência aos enlutados após a morte; respeito às crenças $\mathrm{e}$ valores dos assistidos, sem imposição de religião e atitudes; serviços prestados por voluntários da comunidade, para atividades de suporte ( companhia, lazer, ajuda na realização de tarefas domésticas, etc. ). A assistência hospice tem como missão melhorar a qualidade de vida restante ao paciente em fase terminal, dar apoio integral também a seus entes queridos, tornando digno e menos doloroso o processo de morte ( Paradis 1985, NHO 1999 ). 
Seus números - unidades existentes, atendimentos realizados e recursos financeiros consumidos - são expressivos e crescentes. Em 1994 o Medicare ${ }^{26}$ pagou aos serviços de hospice o total de 1,32 bilhões de dólares, para a assistência a 221.849 pacientes ( Christakis e Escarce 1996 ). Em pesquisa publicada pelo National Center for Health Statistics dos Estados Unidos 1.800 serviços prestavam assistência hospice nesse país em 1996, tendo atendido a um total de 393.200 pacientes durante o ano anterior ( Haupt 1998 ). Em 1998 a National Hospice Organization registrava mais de 2.800 associados, entre serviços de pequeno e médio porte, filantrópicos e lucrativos ( N.H.O. 1999 ). Estima-se hoje que cerca de 500.000 pacientes, dos 2,3 milhões que morrem anualmente nesse país, recebam assistência hospice ( Callahan 2000 ). A diversidade de modelos operacionais existentes, a incorporação de trabalho voluntário e a subjetividade da atribuição de valor monetário à qualidade das relações interpessoais - matéria prima desses serviços - dificultam a realização de pesquisas de custos dos hospices. Apesar de sua complexidade, no entanto, alguns estudos desse tipo têm sido realizados, demonstrando economia menor do que a esperada, ao se comparar a assistência nos hospices com os atendimentos convencionais (Emanuel 1996 ). A dificuldade para controlar os gastos com assistência à saúde tem levado o governo americano a se preocupar com a contabilidade dos hospices, levantando a importância de estudos comparativos de custos nos vários serviços ( Haupt 1998 ). Segundo alguns autores, o governo americano e as empresas de saúde podem estar vendo o modelo hospice de assistência - entre outras propostas de atendimento aos doentes em fase terminal - primariamente como um modo de economizar dinheiro (Bilchik 1996, Naierman 1998 ). Defensores do modelo hospice de cuidados tanto utilizam esse argumento a seu favor, enfatizando as possibilidades de contenção de gastos com essa forma de assistência ao final da vida ( Gillick 1994, Christakis e Escarce 1996 ) como apontam para os perigos desse enfoque, notadamente o

\footnotetext{
${ }^{26}$ Cerca de $80 \%$ dos pacientes que recebem assistência hospice nos Estados Unidos da América são beneficiários do Medicare, seguro-saúde público de cobertura universal para maiores de 65 anos. Cerca de 27 a $30 \%$ do total dos recursos do Medicare são consumidos com despesas realizadas no último ano de vida de seus beneficiários, em todos os tipos de assistência; destes recursos, cerca de $52 \%$ se concentram nos últimos 60 dias de vida ( Lubitz e Riley 1993 ). Os gastos com a assistência à fase final da vida, nesse pais, demonstrados em estudos do final dos anos 80 e repetidos até hoje, consomem $10 \%$ de todos os recursos financeiros da saúde, dai o forte apelo à sua contençăo. ( Gillick 1994, Bilchik 1996, Lonberger et al. 1997 )
} 
de se considerar o doente em fase terminal como não merecedor de investimentos financeiros. Lideranças desses serviços reclamam das restrições impostas pelo governo para o reembolso dos atendimentos, como: limitação da assistência a um período máximo de 6 meses, não pagamento de procedimentos e medicamentos tidos como curativos, existência de um teto máximo de cobertura de custos por paciente, exigência de pelo menos $80 \%$ de cobertura em assistência domiciliar. Lamentam também - e cobram das instituições de saúde governamentais - a falta de esclarecimentos à população a respeito desse serviço ( Naierman 1998 ).

As restrições referidas acima parecem contribuir para o encaminhamento tardio dos pacientes ao atendimento hospice, nos Estados Unidos da América. Estudos de sobrevida dos pacientes nesses serviços têm demonstrado, quase que invariavelmente, duração média inferior a dois meses, bem menor portanto que o limite de 6 meses admitido pelo sistema de seguro-saúde (Christakis e Escarce 1996, Haupt 1998 ). Um importante fator arrolado como responsável pelo adiamento do início da assistência especializada à fase terminal é a dificuldade de realização de prognósticos acurados por parte dos médicos, dificuldade essa devida tanto a questões de ordem técnica como também emocional. Por outro lado, a relutância dos pacientes e de seus familiares para aceitar um prognóstico indesejável também tem sido considerada como causa freqüente de encaminhamentos tardios aos hospices. (Christakis e Escarce 1996 )

A qualidade do atendimento realizado, tanto em hospitais convencionais quanto nos hospices também tem sido foco de atenção, nos Estados Unidos. Um dos estudos mais conhecidos sobre cuidados hospitalares aos doentes em fase terminal é - SUPPORT ( Study to Understand Prognoses and Preferences for Outcomes ). Esse trabalho, iniciado em 1992, foi realizado em 5 hospitais-escolas americanos, para identificar e corrigir problemas na assistência aos pacientes morrendo. Em sua primeira fase, de observação ( dois anos de seguimento, 4301 pacientes ), esse estudo verificou: alta incidência de dor ao final da vida, tratamentos agressivos freqüentes, excessivas internações em UTIs e desconhecimento médico sobre as preferências dos pacientes a respeito de intervenções e prolongamento artificial da vida. Após a fase seguinte, de dois anos de atividades educativas nos mesmos locais ( envolvendo 
mais 4804 pacientes e seus médicos ), não se detectou qualquer melhora no atendimento aos pacientes, no que se refere às variáveis: comunicação médicopaciente, alívio de dor, tempo de internação em UTI e observância das ordens de não ressuscitar. Esses resultados demonstram a necessidade de medidas mais poderosas que intervenções pontuais para que se possam efetivar as mudanças pretendidas. Isto é: apontam para a necessidade de reformulação mais ampla do sistema de assistência médica e, principalmente, de mudança de valores e atitudes de toda a sociedade ( SUPPORT 1995, Feinberg 1997 ).

A dificuldade da maioria dos profissionais para lidar com a morte afasta o paciente daqueles que deveriam estar preparados para ajudá-lo ( Kovács 1991, AMA 1996 ). Estudos de procedências diversas mostram que a má comunicação entre profissionais de saúde e doentes agonizantes é um problema universal, assim como a precariedade dos cuidados dispensados nos hospitais modernos aos pacientes sem possibilidades de cura. ( Webster 1981, Mills et al. 1994, Vianna e Piccelli 1998 ). Segundo Bulkin e Lukashok: "Médicos são treinados para investigar, diagnosticar, prolongar a vida e curar. Quando essas ações perdem a relevância, eles acham que não têm o que fazer pelo paciente, e se distanciam" ( Bulkin e Lukashok 1988 p. 377 ). De fato, a educação médica é feita usuamente em hospitais para tratamento de doenças agudas, onde os estudantes não têm oportunidades de aprender sobre tratamentos de longa duração, tratamento domiciliar, reabilitação e cuidados ao fím da vida ( Steel et al. 1999 ). Além disso, algumas habilidades importantes para assegurar a competência médica na assistência aos pacientes em fase terminal não são ensinadas nas escolas de graduação, como habilidades em comunicação, tomada de decisões, resolução de conflitos, relacionamento, trabalho em equipe ( von Gunten et al. 2000 ).

As pesquisas sobre a assistência médica ao final da vida nos hospitais têm demonstrado uma grande dificuldade de comunicação entre os médicos e seus pacientes e familiares. Muito freqüentemente esses profissionais desconhecem as preferências de seus pacientes sobre as condiçð̃es de sua morte, bem como as suas necessidades espirituais e pendências a serem resolvidas, responsáveis por aumento do sofrimento, estresse e sintomas como ansiedade, depressão, insônia. Bem poucas vezes conhecem as expectativas do paciente sobre o tratamento instituído. A falta de 
treinamento médico para a comunicação de más notícias e a relutância da sociedade ocidental atual para lidar com o tema da morte convergem para dificultar ainda mais a relação médico-paciente nessa fase ( Quill e Townsend 1991, Novack et al. 1997 ). Como resultado, os pacientes quase invariavelmente não são informados corretamente sobre a gravidade de sua situação, muitas vezes recebendo as informações de maneira evasiva, apressada, sem levar em consideração suas reais preocupações ( McCormick e Conley 1995, Lo et al. 1999 ). A relação entre pacientes em fase terminal e os profissionais de enfermagem também deixa muito a desejar, conforme mostrado em vários estudos. Basicamente esses trabalhadores sofrem das mesmas dificuldades e lacunas de formação sentidas pelos médicos; porém, devido ao maior contato com os doentes, ficam mais expostos a uma possivel sobrecarga emocional, da qual muitas vezes procuram se defender afastando-se dos doentes ( Webster 1981, Ghezzi 1991 ). O modelo hospice de cuidados enfoca precisamente a qualidade da relação profissional-paciente, dispensando atenção individualizada a cada um, ressaltando a importância de ouvir e de estar ao lado do paciente, valorizando o tempo de vida que lhe resta (Clark 1997, Byock 1996 ).

Estudos comparativos realizados entre usuários de serviços convencionais e de hospices têm mostrado que os últimos - tanto os doentes quanto os familiares freqüentemente expressam um maior grau de satisfação com o atendimento recebido ( Dawson 1991 ). Além disso, a probabilidade dos pacientes virem a morrer em suas casas é bem maior entre aqueles atendidos em hospices (Moinpour and Polissar 1989)

A identificação e definição do que seria aceitável como uma boa morte também tem envolvido os pesquisadores do tema. Trabalhos sobre avaliação clínica, sintomas gerais e particulares do processo de morrer, expectativas, desejos e valores dos pacientes e da sociedade têm sido publicados ( AMA 1996, Emanuel e Emanuel 1998, Callahan 1995, 2000 ). Prevalece um consenso, assumido pelo Instituto de Medicina Americano, de que a morte decente ou boa é a que é livre de sofrimento $e$ desconforto evitáveis para pacientes, familiares e cuidadores, está o mais possível de acordo com os desejos dos pacientes e familiares e é razoavelmente consistente com os padrões clínicos, culturais e éticos vigentes (Emanuel e Emanuel 1998 ). Morrer em casa, e não em hospitais, tem sido uma das preferências mais regulares 
reportadas nas pesquisas, em vários países, em investigações junto a pacientes acometidos por doença grave, ou a pessoas sãs ( Ventafridda 1991, Kai et al. 1993, Thorpe 1993, AMA 1996 )

A definição de terminalidade, essencial para a indicação do tratamento tipo hospice nos Estados Unidos também tem suscitado muitas discussões. De acordo com o sistema de saúde oficial, que reembolsa as agências prestadoras de serviços, o paciente só se torna elegivel a esse tratamento se tiver um prognóstico médico de tempo de vida igual ou inferior a seis meses. Sendo esse o periodo máximo de assistência em hospice a ser pago por paciente pelo Medicare ( para maiores de 65 anos ) e Medicaid ( para pacientes sem outras fontes de financiamento, em certas circunstâncias devidamente comprovadas ), também aceito pelas empresas privadas de seguro-saúde, a sobrevida de 6 meses passou a ser usada correntemente nesse país como um dos definidores de estágio terminal, juntamente com indicadores clínicos de piora irreversível do quadro patológico. A dificuldade de exatidão prognóstica na área médica, no entanto, torna essa avaliação bastante complexa, principalmente em pacientes acometidos por doenças de evolução irregular. Não por acaso, a grande maioria do pacientes que recebem assistência tipo hospice nos Estados Unidos da América são portadores de neoplasias malignas, patologias com evolução mais facilmente antecipada, tanto pelos médicos, como também pelos próprios pacientes ( SUPPORT 1995, AMA 1996, Haupt 1998 ). Para fazer frente a essa dificuldade, tanto as instituições financiadoras ( Medicare, empresas privadas de seguro-saúde ) como as prestadoras dos serviços hospice, têm divulgado guias e critérios para elaboração de prognósticos mais acurados, para cada uma das doenças crônicas mais comuns ( Lynn 1996 ). No entanto, o prognóstico, parte essencial da prática médica, segue sendo uma atividade pouco acurada, com avaliações que tendem - majoritariamente - a superestimar a sobrevida dos pacientes (Christakis e Lamont 2000 ). O prognóstico é uma aposta, um ato impreciso, no limite entre a ciência e a arte. Adaptaçð̃es de instrumentos e sistemas utilizados em terapia intensiva, como os sistemas APACHE II e outros similares têm sido recomendados e utilizados, embora sejam mais adequados para avaliação de situações clínicas agudas (Esserman et al. 1995, AMA 1996, Marshall 1999 ). 
Diferente da dificuldade prognóstica, acima referida, existem hoje situações claramente identificáveis em que a irreversibilidade de um quadro clínico pode ser tida como certa. Condições de vida artificial viabilizadas pela tecnologia moderna, fazem com que pacientes em coma profundo possam viver indefinidamente, dependentes de aparelhos e de cuidados especializados para o desempenho de suas funções vitais. Essas situações criam sérios impasses para o médico e os familiares do paciente acometido, e para o sistema de saúde e a sociedade em geral, no estabelecimento das condutas mais apropriadas.

Vários instrumentos legais foram criados nos Estados Unidos da América, nos últimos anos, para auxiliar a tomada de decisão médica nas fases críticas dos tratamentos, em comum acordo com os pacientes envolvidos, ou seus responsáveis. Esses instrumentos foram motivados pelas preocupações éticas mais recentes, que promovem a valorização e instituição do direito à informação e a autonomia dos pacientes ou de seus representantes legais. Desse modo, as manobras ressuscitadoras que eram realizadas rotineiramente em todas as pessoas morrendo em hospitais nesse país, desde os anos 70, passaram a ser uma opção do doente já na década seguinte. Assim também alguns procedimentos como a manutenção da atividade cárdiorespiratória através de máquinas e aparelhos, a alimentação parenteral e a administração intravenosa de fluidos, que propiciem o prolongamento artificial da vida, são agora passíveis de escolha ou de rejeição pelos pacientes, de forma legal. O "Patient Self-Determination Act" ( lei americana que estabelece o direito do paciente a realizar antecipadamente essas escolhas, de 1990 ), no entanto, só pode ser benéfico `a medida em que os pacientes tenham recebido todas as informações necessárias às suas decisões - mesmo que essas decisões sejam usualmente tomadas à base de conjecturas - e que se possa garantir que os médicos respeitarão essas decisões, no momento oportuno. Estudos têm mostrado que as mudanças nas práticas hospitalares são ainda incipientes, e que mesmo as ordens de não realização de manobras ressuscitadoras ( conhecidas como "DNR" = "Do Not Ressuscitate") implantadas nesse país há mais de uma década, são freqüentemente desconsideradas - ignoradas ou simplesmente desobedecidas - pelos médicos ( Danis et al. 1991, SUPPORT 1995, AMA 1996, Feinberg 1997 ). 
Preocupações éticas e legais mais recentes, como com eutanásia e distanásia ( boa e má morte, respectivamente ) e com o suicídio sob assistência médica ${ }^{27}$ têm mobilizado bastante o cenário dos cuidados aos doentes em fase terminal nos Estados Unidos, com grande volume de publicações e debates. O uso de sedativos potentes com o intuito de aliviar a dor ou sofrimento, e que podem acelerar mesmo que não intencionalmente - o processo de morte, também é um dos temas bastante abordados nesse país, ultimamente. O surgimento eventual de médicos ou outros profissionais de saúde que advogam publicamente a indução ou aceleração da morte de doentes que sofrem, ainda que agindo individualmente e em notória divergência com o modelo de assistência dominante, tem contribuído em muito para acalorar esses debates ( o conhecido Dr. Kervokian, referido pela imprensa como "Anjo da Morte", é um bom exemplo ). Alguns casos relacionados ao direito de morrer chegaram aos tribunais americanos com grande cobertura da mídia e impacto popular, como o caso Quinlan, ainda nos anos 70 , em que os familiares da paciente em coma profundo irreversivel solicitavam o direito de lhe retirar o suporte respiratório mecânico. $\mathrm{O}$ desligamento dos seus aparelhos foi considerado legal $\mathrm{e}$ ético, nessas condições, e foi realizado; a paciente Quinlan sobreviveu por vários anos após a retirada do suporte artificial de vida. Esse caso ficou bastante conhecido nesse país e gerou jurisprudência válida ainda hoje ( Robin 1984, Brody 1992 ).

$\mathrm{O}$ respeito simultâneo à autonomia médica e ao direito do paciente nem sempre convergem na tomada de decisões, podendo gerar situaç̃̃es conflituosas em momentos críticos, como prolongamento artificial da vida ( Helft et al. 2000 ). Autores como Lo et al. creditam o apoio público à legalização do suicídio assistido ao medo de sofrimento, abandono e perda de controle, ao medo da morte mal assistida nos hospitais ( Lo et al. 1999 ). Já outros, como Feinberg e Meier et al., questionam o entendimento de pacientes e familiares sobre o potencial curativo da Medicina - na realidade bem menor do que é costumeiramente divulgado pela mídia - quando optam por tratamentos fúteis (Feinberg 1997, Meier et al. 1997. Nesses casos, a decisão ficaria comprometida tanto por uma inadequada avaliação leiga das chances reais de cura dos doentes, quanto pelos desejos ambivalentes presentes (Feinberg 1997 ).

${ }^{27}$ O Oregon é o único Estado americano em que essa prática é legal, desde 1997 ( Chin et al. 1999 ). 
O campo da assistência à fase final da vida vem se constituindo rapidamente nos países desenvolvidos nas últimas décadas, à medida em que cresce a prevalência de doentes crônicos nas populações, e a tecnologia médica se capacita mais e mais a prolongar a vida de doentes incuráveis, trazendo novos problemas e novas soluções. O modelo hospice de assistência tem sido implementado em diversos países, e a importância dos cuidados paliativos - o conceito hospice de assistência dirigido a doentes em qualquer fase da doença - crescido bastante, a ponto de já constituir uma nova especialidade médica na Inglaterra (Rousseau 1995 ).

O modelo hospice de assistência desenvolveu-se e expandiu-se rapidamente na Inglaterra, em suas diversas modalidades, nas décadas de 70 e 80 ( Lunt 1985 ). No entanto, vinte e cinco anos após sua criação, os hospices modernos ingleses ainda dependiam fundamentalmente da caridade pública para seu sustento, e pertenciam majoritariamente ( $75 \%$ ) a uma rede não governamental de instituições destinadas ao controle do câncer ( National Society for Cancer Relief), gerando inequalidades na distribuição de leitos ( Lunt 1985, Douglas 1992 ). Só mais recentemente o Sistema Nacional de Saúde inglês passou a incorporar oficialmente o atendimento hospice e a financiá-lo, destinando leitos a portadores de outras patologias que não o câncer. Estudo realizado em Londres verificou aumento da morte domiciliar e em hospices de doentes com aids, desde o final dos anos 80 , dado este tomado como indicador de melhoria da qualidade do atendimento, uma vez que implica em maior participação dos pacientes nas decisões sobre seus tratamentos ( Guthrie et al. 1996 ).

As mortes em instituições tipo hospices também cresceram na Austrália na década de 80 , principalmente de pacientes com câncer, com diminuição das mortes em hospitais privados. $O$ aumento do número de casos de câncer na população, $o$ alto custo da assistência médica e o desenvolvimento de serviços de cuidados paliativos têm aumentado o interesse em diferentes modelos de cuidados à fase terminal, nesse país ( Hunt et al. 1993 ).

Diferente do que ocorreu na maioria dos países, em que os cuidados paliativos foram introduzidos através dos serviços de Oncologia, no Canadá estes se originaram nas instituições universitárias, estendendo-se posteriormente às demais ( MacDonald 1998 ). Hoje o Canadá tem muitos serviços dedicados à assistência a 
doentes em fase terminal e conta com grande experiência no modelo hospice de assistência, incluindo o atendimento a pacientes portadores de aids (Goldstone 1992 ).

A morte domiciliar vem sendo implementada também na Dinamarca, onde os cuidados a doentes em fase terminal são ensinados e praticados há mais de quatro décadas ( Pallesen 1992). A filosofia hospice de atendimento e a educação profissional em cuidados paliativos vêm sendo introduzidos com sucesso na Noruega, onde o sistema de assistência à saúde é altamente desenvolvido (Husebo 1991 ).

Desde os anos 80 têm sido realizados esforços no Japão para melhorar o atendimento aos doentes em fase terminal, como: encorajar a comunicação médicopaciente a respeito de diagnósticos, promover a participação do doente nas decisões sobre tratamento, e aumentar o uso de drogas para controle de dor ( Kimura 1991 ).

Os cuidados paliativos foram introduzidos na Itália no final dos anos 70 e se desenvolveram de modo heterogèneo no país, devido à ausência de envolvimento das autoridades nacionais e à falta de uma legislação clara sobre o assunto, a despeito de esforços de seus divulgadores e alguns sucessos obtidos ( Sbanotto e Burnhill 1998 ).

A morte domiciliar vem sendo resgatada em muitas sociedades, diminuindo a medicalização desse processo, embora o estudo SUPPORT tenha evidenciado que, ao menos nos Estados Unidos da América, o local de morte é fortemente associado às características do sistema local de saúde, e não às características do paciente ou suas preferências ( Pritchard et al. 1998 ). Na Espanha, a implementação do atendimento domiciliar, favorecendo o alívio adequado dos sintomas dos pacientes e o suporte aos familiares cuidadores, aumentou a proporção de mortes em domicílio ( Sanz-Ortiz et Llamazares Gonzalez 1993 ).

Outras sociedades, desenvolvidas ou não, têm se envolvido na busca de modelos de prestação de assistência aos doentes em sua fase final. Os ensinamentos trazidos por Dame Cicely Saunders e pelos hospices americanos e seus seguidores têm iluminado as novas experiências. Mesmo países pobres ou em desenvolvimento têm reportado experiências nesse campo, em todos os continentes, como países do leste europeu ( Polônia, Rússia, Hungria ), da África ( Quênia ), e também da América Latina ( Chile, Colômbia ) ( Luczak e Hunter 2000, Merriman 1991, Rico 1997, Lima 1993 ). 
Várias modalidades de serviços têm surgido, dependendo das necessidades, circunstâncias e possibilidades reais existentes em cada país. $O$ modelo de sistema de saúde vigente e a cultura local influenciam fortemente as escolhas, principalmente no que se refere à predominância do regime de atendimento, se domiciliar ou em internação. Quanto a esse último regime existem várias possibilidades de assistência já experimentadas, como: internação em unidades próprias ou hospices propriamente ditos, internação em enfermarias de hospitais gerais especialmente destinadas a esses pacientes, ou internação em leitos espalhados em hospital geral. As vantagens e desvantagens de cada uma dessas modalidades de atendimento a pacientes internados são facilmente encontradas na literatura especializada, com detalhamento variável.

Podem ser assim resumidas ( Paradis 1985 ):

* Unidade própria ou hospice: o conceito hospice de cuidados pode ser melhor utilizado, a equipe profissional melhor dirigida e o controle de qualidade melhor assegurado; em contrapartida o estigma de local da morte encontra mais chances de se ligar ao serviço e em conseqüência diminuir sua aceitação, a realização de procedimentos tipicamente hospitalares é mais difícil, e há maiores resistências para o encaminhamento dos pacientes.

* Enfermaria especial, em um hospital geral: há facilidade de referenciamento dos pacientes entre as enfermarias, há intercâmbio de conhecimentos entre as equipes de hospice e as demais, há facilidade para administração de recursos se o serviço conta com bom respaldo dentro do hospital, há facilidade para adequação de parte dos regulamentos e estruturas hospitalares a essa parcela da clientela ( se comparada à situação de leitos esparsos ); as desvantagens se devem ainda à possibilidade de manutenção do estigma, e à dependência dessa unidade à administração geral do hospital, que pode não valorizá-la, desconsiderando as necessidades especiais dessa forma de assistência.

Leitos esparsos em hospital geral: as vantagens se devem à sua facilidade de implantação, que requer minimas modificações de espaço e de pessoal, à livre utilização de leitos para pacientes em fase terminal ou em tratamento curativo, e à possibilidade de divulgação da filosofia hospice de atendimento entre os 
demais profissionais. As desvantagens são: dificuldade de treinamento, guia e supervisão dos profissionais, dificuldade de entendimento da filosofia hospice de cuidados por parte do paciente e seus familiares, dificuldade de implantação de regime diferenciado de visitação, de alimentação, etc. em virtude da proximidade com os pacientes em tratamento curativo que requerem outra forma de manejo, maior dificuldade para a formação de uma rede de suporte entre familiares de diversos pacientes, dificuldade para avaliação de resultados. Quanto ao relacionamento profissional, o paciente pode continuar sob a responsabilidade das equipes médica e auxiliar que vinham lhe prestando o tratamento curativo, recebendo cuidados adicionais de uma equipe de cuidados paliativos ou de hospice que preste o atendimento em regime de inter-consulta, ou então ser atendido exclusivamente pela equipe de hospice.

Existem serviços que oferecem assistência em todas essas modalidades, e outros que se especializam em apenas uma forma de atendimento.

O sucesso que o modelo hospice de assistência ao doente que está morrendo conseguiu obter nos países em que foi implantado se deve principalmente à uma leitura acurada das tendências sociais e à habilidade para preencher uma lacuna nos serviços médicos, por parte dos promotores dessa filosofia de cuidados ( Greer 1983 ). Nesse modelo, o atendimento ao doente em fase terminal visa melhorar a qualidade da vida restante ao paciente, reconhecendo que morrer não é uma falência da assistência médica mas sim, um processo natural. Propõe mudar o foco dos cuidados, de curativos para paliativos, evitando procedimentos invasivos desnecessários e propiciando o alívio dos sintomas que a moderna tecnologia farmacológica tornou possível. Requer também dar suporte, orientação e informações aos familiares dos pacientes, encorajando-os nas tomadas de decisão que se fizerem necessárias, tratando não apenas o paciente mas todo o grupamento familiar envolvido. Esse novo enfoque assistencial implica em ouvir as necessidades do paciente de um modo individualizado, conferindo-lhe direitos negados dentro do sistema convencional de atendimento hospitalar. Tem, por isso mesmo, implicações na relação profissionalpaciente, na prática médica, e na administração de serviços de saúde. Suas chances de implantação em uma determinada sociedade dependem muito dessas variáveis. 
O conceito hospice de assistência ao doente em fase terminal inspirou o aparecimento de uma nova especialidade médica: a Medicina Paliativa, que é a parte dos Cuidados Paliativos realizada por médicos. Ao ser reconhecida na Grã-Bretanha, em 1987, essa especialidade foi assim definida: "Medicina Paliativa é o estudo e controle de pacientes com doença ativa e progressiva em fase avançada, para os quais o prognóstico é limitado e o foco dos cuidados é a qualidade de vida." ( Gilbert 1996, p. 296 ). A Medicina Paliativa vem se desenvolvendo com a maior importância conferida à qualidade de vida de pacientes crônicos, nos quais o controle da dor e de outros sintomas tem papel crucial, independentemente do tempo de sobrevida provável do paciente. Nos Estados Unidos da América vária instituições oferecem cursos a médicos sobre essa temática ( Billings e Block 1997 ). O crescimento da importância conferida aos aspectos clínicos e à pesquisa em cuidados paliativos, bem como a implantação de equipes de cuidados paliativos nos hospitais gerais para atender àqueles doentes sem possibilidades de cura, mas sem indicação de atendimento hospice, têm ajudado a aumentar adesão de médicos aos cuidados paliativos. A indicação de cuidados paliativos independe da fase da doença, podendo coexistir com o tratamento curativo, muitas vezes substituindo-o gradualmente, em um "continuum" de cuidados ( Higginson 1993, MacDonald 1998, Byock 2000 ).

Já nos anos 70, nos Estados Unidos da América e na Grã Bretanha, verificou-se a necessidade da ação de equipes multi-profissionais especializadas em cuidados a doentes em fase terminal nas enfermarias de hospitais gerais. O St Luke's Hospital, em Nova Iorque e o St. Thomas' Hospital, em Londres, foram os pioneiros ( Hockley 1999 ). A incorporação dos cuidados paliativos em hospitais gerais beneficia um maior número de pacientes, uma vez que nem todos têm condições ou recebem indicação da assistência hospice. Limitaçð̃es próprias da avaliação prognóstica, dificuldades de aceitação da morte iminente - já referidas anteriormente - além de questões referentes à acessibilidade dessa forma especializada de assistência mantêm um grande contingente de doentes em fase final nos hospitais. Desse modo os cuidados paliativos, ou seja: o conhecimento e a prática redescobertos e atualizados de assistência aos doentes sem possibilidades de cura, nascidos à margem das instituiç̃es tradicionais de prestação de serviços de saúde, rapidamente retornaram 
aos hospitais. A despeito de alguma controvérsia a respeito da criação de uma nova especialidade médica, veiculada pela literatura científica, a Medicina Paliativa vem se desenvolvendo nos paises onde existe o atendimento hospice e até em outros, como se pode depreender pela ampla divulgação de associações, congressos e publicações especializados no tema (Fordham et al.1998, Holman e Smith 1999 ).

No Brasil uma nova abordagem da assistência ao doente que está morrendo também vem se desenvolvendo desde o início da década de oitenta, principalmente em instituições de ensino e pesquisa das regiões sul e sudeste do país. Já em 1982 o Seminário Interdisciplinar sobre "A morte e os mortos", realizado em São Paulo por Martins, representou um marco para os estudos nessa área, ao reunir profissionais de diversas formações para compartilharem suas experiências (Martins 1983, Boemer et al. 1991 ). Também nesse ano foi publicado em revista médica paulista um artigo abrangente sobre a assistência ao doente que morre em hospitais, com abordagem semelhante à do conceito hospice de assistência, conceito este bastante recente nos países desenvolvidos, nessa época (Louzã e Louzã Neto 1982 ).

Importantes iniciativas em pesquisa e educação, focalizando o atendimento ao paciente em fase terminal e o (des)preparo dos profissionais de saúde para lidar com a morte e o morrer foram realizadas, desde então. Entre outros, destacam-se os trabalhos pioneiros de Kovács ( realizando cursos de Psicologia da Morte, na Faculdade de Psicologia da USP desde os anos 80 ) e de Torres ( coordenando grupo de estudos e pesquisas sobre tanatologia, no Rio de Janeiro ) no campo da psicologia e de Boemer e Paduan no campo da enfermagem, cujas experiências foram relatadas na literatura nacional especializada (Boemer et al. 1991, Cassorla 1991, Kovács 1991 ).

A inadequação da educação médica para o lidar com a morte e o morrer também tem sido focalizada em diversos estudos, resultando quase invariavelmente em propostas de modificação curricular (Zaidhaft 1990, Sayd 1993, Vianna e Piccelli 1998 ). Em meados dos anos 90 foram instituídos cursos de Cuidados Paliativos e de Tanatologia junto a uma importante escola médica ( UNIFESP ) na cidade de São Paulo, inicialmente como cursos de extensão de graduação, e atualmente como disciplina de caráter eletivo. Apesar de sua inegável importância e excelente apreciação por parte dos alunos, esses cursos têm sido realizados sem suporte 
financeiro institucional, existindo graças à dedicação de seu organizador e principal executor ( Figueiredo 1997, 1999 ). Mais recentemente outro centro de educação médica ( FMUSP ) realizou cursos extra curriculares semelhantes ( Figueiredo 1999 ). No entanto, esses esforços isolados são a exceção, na capacitação médica brasileira.

A qualidade de vida de pacientes em fase terminal foi objeto de pesquisas também no Brasil, buscando trazer subsídios para a melhoria da sua assistência: pelo menos dois importantes estudos foram realizados nos anos 90 no Estado de São Paulo. Entre outros resultados, eles confirmaram a precariedade da comunicação entre os profissionais e o paciente e familiares e também entre pacientes e familiares (Bromberg 1998 ); a alienação do paciente sobre seu tratamento e prognóstico, a falta de uma estrutura de assistência domiciliar; a preocupação do doente com os altos custos dos tratamentos (Kovács et al. 1998 ).

A publicação de artigos e/ou livros na literatura técnica nacional abordando a assistência aos pacientes em fase terminal, ou aspectos de cuidados paliativos vem aumentando sensivelmente nos últimos anos. No entanto, é provável que outras experiências importantes nesse campo estejam sendo desenvolvidas, sem serem divulgadas. Segundo a Associação Brasileira de Cuidados Paliativos, organização criada em Outubro de 1997, existem, em todo o país, cerca de 26 serviços prestadores de cuidados paliativos por ela cadastrados. ${ }^{28} \mathrm{Nem}$ todos capacitados a prestar assistência ao paciente que está morrendo, quer seja por insuficiência e inadequação estrutural ou funcional. Merecem destaque o Centro de Terapia da Dor e Medicina Paliativa do Hospital Amaral Carvalho, de Jaú (SP), criado em 1992, e o Serviço de Cuidados Paliativos do Hospital Nossa Senhora da Conceição, de Porto Alegre (RS), que prestam assistência tipo hospice a pacientes internados em leitos próprios. A grande maioria dos serviços de cuidados paliativos dos quais se tem conhecimento no Brasil está voltada para a paliação de sintomas de doentes de câncer em fase avançada, principalmente terapia da dor, em regime ambulatorial ou como consulta especializada a doentes internados, a pedido dos responsáveis pelo

\footnotetext{
${ }^{28}$ Em virtude da falta de dados nacionais sobre os serviços especializados existentes, publicados na literatura científica, conta-se com informaç̃̃es orais e uma listagem de serviços e instituições divulgada pela Associação Brasileira de Cuidados Paliativos em Março de 2000, durante realização do III Seminário Internacional de Cuidados Paliativos, em São Paulo.
} 
tratamento do doente. Os serviços pioneiros iniciaram essa modalidade de atendimento já em 1983: as equipes especializadas do Hospital de Clínicas de Porto Alegre (RS) e da Santa Casa de São Paulo ( Figueiredo 1997 ). No município de São Paulo atualmente existem pelo menos sete serviços de cuidados paliativos, a maioria sediada nos grandes hospitais universitários. A Unidade de Cuidados Contínuos do Hospital Pérola Byington da Secretaria de Estado da Saúde de São Paulo, que presta atendimento domiciliar a pacientes portadoras de câncer ginecológico, a maioria sem possibilidades de cura, é um dos raros serviços públicos que conta hoje com experiência considerável na formação e suporte a cuidadores e na assistência ao óbito domiciliar. Os Serviços de Atendimento Domiciliar do Centro de Referência e Treinamento em DST/Aids da Secretaria de Estado da Saúde de São Paulo e da rede municipal já contam hoje com uma pequena porém significativa experiência no atendimento a pacientes com aids em fase avançada, mas o óbito domiciliar desses pacientes ainda é pouco freqüente. $\mathrm{Na}$ experiência desses serviços os pacientes moribundos geralmente são transferidos para os hospitais pelos próprios familiares. Dificuldades de locomoção em tempo hábil têm impedido o atendimento ao paciente e familiares nas fases críticas, segundo comunicação oral à pesquisadora por membros dessas equipes. Mesmo assim, o profissional da equipe de atendimento domiciliar auxilia os familiares a providenciar a declaração de óbito, solucionando uma das maiores dificuldades do óbito domiciliar.

Os profissionais que prestam cuidados paliativos no Brasil têm contado, quase sempre, apenas com o esforço individual e apoio da literatura especializada para sua formação e atuação ( Carvalho e Kovács 1998 ). Algumas instituições e/ou profissionais estrangeiros têm fornecido suporte educacional para essas novas experiências, que nem sempre gozam de significativo respaldo institucional local. Apesar do crescimento do interesse que esse tema vem despertando entre os profissionais de saúde, nota-se no Brasil, ainda hoje, aparente desinteresse por parte das autoridades sanitárias, das escolas de graduação e especialização em ciências da saúde, e dos gerenciadores de serviços de saúde públicos e privados, pelo atendimento aos doentes em fase terminal. 
A experiència realizada em outros paises, principalmente Estados Unidos da América e Inglaterra, tem trazido muitos subsídios aos profissionais brasileiros que se sentem desconfortáveis com a qualidade do atendimento aqui realizado, e que vêm realizando as mudanças possíveis em suas práticas cotidianas. Esses profissionais têm divulgado seus conhecimentos aos demais através de palestras, simpósios, cursos e conferèncias, dando início a uma rica troca de idéias e vivências, desde há alguns anos. Segundo organizadores e participantes, esses eventos têm sido procurados e recebidos com satisfação, demonstrando haver, pelo menos nos grandes centros urbanos do país, um considerável contingente de profissionais de saúde interessado no tema. As publicações encontradas na literatura especializada nacional e as experiências divulgadas nos encontros sobre o tema, confirmam o crescimento de um trabalho sério para melhorar a qualidade da assistência aos doentes em fase terminal, aqui no Brasil, e a busca de novos modelos assistenciais, adequados a nossa situação e possibilidades reais.

Os questionamentos éticos que acompanham a terminalidade, o morrer e a morte, já referidos acima, como eutanásia, distanásia, etc., também têm suscitado um rico debate aqui no Brasil. Médicos, teólogos, juristas e outros profissionais têm trazido importantes subsídios para a nem sempre fácil tomada de decisões nas situações críticas. Um estudo sobre a evolução histórica dos Códigos Brasileiros de Deontologia Médica e Códigos de Ética Mética revela o crescimento da importância dos direitos do paciente, nos últimos anos ( Martin 1993 ). Como no Brasil as normas emanadas pelos conselhos profissionais têm poder coercitivo, seu posicionamento tem importância fundamental na regulamentação das práticas médicas ( Fortes 1998 ). $\mathrm{O}$ dinamismo e a múltipla determinação dos valores nas sociedades tornam o debate amplo e constante uma ferramenta essencial para que as práticas profissionais não se consolidem à revelia dos seus usuários. Segundo Pessini e Barchifontaine, a moral católica ( Pio XII, 1957 ) diz que existe obrigação moral de se utilizar os meios terapêuticos ordinários, nos casos de prolongação da vida em condições precárias, mas não de recorrer a meios extraordinários, deixando os critérios de ser ou não ordinário indefinidos. Para os autores, o paciente que pede a eutanásia está realmente pedindo melhor assistência ( Pessini e Barchifontaine 2000 p. 299-300). 


\title{
VIII - Aids: aspectos clínicos e epidemiológicos; assistência aos doentes
}

\begin{abstract}
"Since we have become better at treating the virus, a new temptation has emerged to du'ell on quantitative aspects of HIV management and monitoring, although the skills that we learned earlier in the epidemic are no less necessary for providing good care. Our new-found therapeutic capabilities should not distract us from the sometimes more difficult and necessary task of simply 'being there' for patients for whom HAART is no longer effective." 29
\end{abstract}

( Selwyn e Arnold 1998, p. 899. )

Desde que os primeiros casos de aids foram descritos pela primeira vez na literatura médica, em 1981, muitas vidas foram ceifadas, em todos os continentes. $O$ acometimento expressivo de adultos jovens, em plena fase produtiva e reprodutiva, tem repercussões graves, como se pode observar em países pobres da África subSahariana, cuja estrutura social e econômica vem sofrendo o grande impacto da aids. As perdas e o sofrimento trazidos pela pandemia de aids têm sido, sem dúvida nenhuma, enormes. Segundo Jonatham Mann, a epidemia de aids progride nos locais onde a capacidade de aprender e de responder está limitada. Pessoas marginalizadas pela sociedade têm menor chance de receber informações adaptadas a suas necessidades, como também de ter acesso a serviços sociais e de saúde, e quase nenhuma chance de se organizar. As respostas a essa epidemia são determinadas pelas condições gerais de vida, incluindo nível de educação, condições de habitação e de emprego ( Mann 1993 ).

A aids é uma doença relativamente recente: seu surgimento ocorreu a partir da década de 60 . Em dez anos atingiu proporções epidêmicas em regiões da África equatorial; os primeiros casos no ocidente apareceram quase simultaneamente nos Estados Unidos da América, alguns países da Europa e Haiti, no final dos anos 70. Fatores sociais importantes contribuíram para a rápida propagação da aids no

\footnotetext{
29 "Desde que nos tornamos melhores no tratamento do virus, surgiu uma nova tentação de fixar-se nos aspectos quantitativas do manejo e monitoramento do HIV, apesar de as habilidades aprendidas no inicio da epidemia não serem menos necessárias para prover uma boa assistência. Nossa capacidade terapêutica recentemente adquirida não nos deveria distrair da tarefa algumas vezes mais dificil e necessária de simplesmente 'estar ai' para os pacientes para os quais a terapia anti-retroviral altamente potente não é mais efetiva."
} 
mundo, como aumento enorme de: viagens internacionais, fenômenos migratórios, atividade sexual, utilização de sangue e produtos sangüíneos para fins médicos e uso de tóxicos por via venosa ( Gallo 1994 ).

A aids foi caracterizada como uma síndrome por apresentar-se com variados sinais e sintomas, geralmente decorrentes da superveniência de outras doenças em um organismo imunologicamente debilitado. Foi denominada Acquired Immuno Deficiency Syndrome - síndrome da imunodeficiência adquirida - em agosto de 1982, pelos investigadores do CDC, o centro para o controle de doenças dos Estados Unidos da América, que lideravam as pesquisas sobre esse novo e letal agravo à saúde ( Garrett 1994 ). Seu agente etiológico é o Vírus da Imunodeficiência Humana, o HIV, isolado em 1983 por pesquisadores franceses e americanos.

O HIV pode ser transmitido de uma pessoa para outra através de contato sexual envolvendo troca de secreções; por via parenteral, em transfusões de sangue e/ou de hemoderivados, ou através do uso de equipamentos médicos e de injeção não esterilizados, e por exposição acidental a sangue e fluidos corpóreos contaminados. Transplantes de órgãos humanos e inseminação artificial também podem ocasionar a transmissão do vírus. Ainda, o HIV pode ser transmitido de mãe para filho durante a gestação, parto e aleitamento materno ( transmissão vertical ).

As vias mais comuns de transmissão, hoje, em todo o mundo, são as relações sexuais desprotegidas ( sem uso de preservativos ). No entanto, existem regiões em que a transmissão principal da aids ocorre por via parenteral, entre usuários de drogas endovenosas que fazem uso compartilhado de equipamento de injeção. A inexistência de métodos preventivos eficazes torna o controle da aids bastante dificil uma vez que, na imensa maioria dos casos, depende basicamente de mudanças comportamentais das populações sadias e infectadas. Segundo a maioria dos pesquisadores, a obtenção de uma vacina eficaz contra a aids ainda é bastante improvável em um futuro próximo, devido a características virais, como a alta mutabilidade do seu agente etiológico, o HIV.

Devido às vias de transmissão do vírus, a aids tem se apresentado em sub grupos populacionais diferentes, ao longo do tempo e nas diversas regiões do mundo, de acordo com o grau de exposição desses grupos. Isso fez com que nos primeiros 
anos da epidemia esta fosse associada fortemente a certos grupos da população, denominados então de categorias de risco, como é o caso dos homossexuais, dos hemofilicos, dos usuários de droga, das pessoas que se prostituem. Além de incorreta do ponto de vista epidemiológico, essa categorização estimula os preconceitos e fortalece o estigma da aids, e vem sendo, portanto, abandonada (Guerra et al. 1996 ). Hoje consideram-se as práticas de risco ( ao invés de categorias ), e a vulnerabilidade individual e social, na literatura especializada. Com a disseminação do vírus à população geral, através de práticas sexuais inseguras - ou seja: envolvendo troca de secreções ( sêmen, secreções vaginais, sangue ), vários parceiros, relação anal receptiva, ferimentos nos genitais, sem uso de preservativos - ( Royce et al. 1998 ) a aids vem sendo cada vez mais considerada uma doença à qual grande parte da população esteja exposta, e não apenas certos grupos populacionais.

No Brasil tem-se notado essa tendência nos últimos anos, embora com dinâmicas distintas nos diferentes segmentos populacionais. Isto é: mesmo que a transmissão heterossexual seja hoje a maior responsável pela disseminação da epidemia, ainda existem segmentos específicos sob alto risco, devido a sua grande vulnerabilidade. Importante salientar que a epidemia vem se disseminando de forma mais lenta, porém mais extensa ( Szwarcwald et al. 1999). Também tem-se observado a disseminação geográfica da aids para além das grandes metrópoles e da região sudeste; o grande aumento da doença entre a população feminina, e por conseguinte maior risco de aids em crianças por via vertical; e clara tendência de acometimento das pessoas com menor grau de instrução - o que vem sendo referido pelos vários autores como a pauperização da epidemia ( Parker e Camargo Jr. 1999 ). A faixa etária mais acometida pela aids, em qualquer país estudado, tem sido a dos adultos jovens, desde o início da epidemia. Além de constituinte majoritário da população economicamente ativa, esse grupo populacional é também o de maior atividade sexual, favorecendo o ciclo de transmissão da aids.

Do mesmo modo que o perfil epidemiológico da aids, a história natural da doença vem sofrendo alterações significativas ao longo do tempo, principalmente devidas à introdução de novos esquemas terapêuticos para seu controle. 
Após a infecção e em um período de incubação variável em torno de uma a algumas semanas, ocorre um rápido aumento da replicação viral, com alta viremia plasmática e subsequente resposta imunológica à infecção, na imensa maioria dos pacientes. Essa fase aguda nem sempre é diagnosticada, uma vez que seus sintomas mais comuns são inespecificos e transitórios, ou até mesmo ausentes, e os anticorpos contra o vírus ainda não são detectáveis pelos testes laboratoriais usuais. Os sintomas mais comuns são: febre, fadiga, exantema, linfadenopatia, mialgia, de curta duração ( Kahn e Walker 1998 ). Cerca de 6 a 12 semanas após a infecção os anticorpos produzidos pelo organismo infectado passam a ser detectáveis através dos testes habituais, do tipo ELISA. Muitos especialistas recomendam o tratamento com terapia anti-retroviral já nessa fase, segundo Nadler, e há fortes argumentos tanto para o início precoce como para retardar o tratamento ( Nadler 1999 ). No Brasil recomenda-se iniciar o uso de drogas anti-retrovirais logo após a contaminação apenas em caso de acidentes ocupacionais.

O período que se segue 'a infecção inicial é conhecido como período de infecção assintomática. Os indivíduos afetados são chamados de portadores do vírus. Embora antigamente se pensasse que essa fase fosse de latência viral, hoje se sabe que o HIV encontra-se ativo no organismo infectado, replicando-se e causando resposta imunológica no hospedeiro, mesmo que inaparente ( Zuger and Sharp 1997 ). A duração da fase de infecção é extremamente variável, de alguns meses a mais de dez anos, dependendo de vários fatores, ligados ao vírus ( virulência da cepa ), à situação de transmissão ( via, volume do inóculo ) e ao indivíduo infectado (idade, fatores de resistência específicos e inespecíficos, ainda em estudo, como padrões genéticos de portadores do vírus que não desenvolveram a doença conhecidos como "long-term survivors" ). Esse período tem aumentado e provavelmente deve aumentar mais, como resultado de tratamentos cada vez mais eficazes, e também de variaçðes virais ( Veugelers e Schechter 1996 ). Os pacientes infectados pelo HIV são potencialmente infectantes, em qualquer fase.

Embora assintomáticos, ou com poucos sinais e sintomas, como perda de peso, linfadenopatia generalizada, manifestações cutâneo-mucosas, astenia, etc., os indivíduos infectados pelo HIV têm seu sistema imunológico progressivamente 
comprometido. A contínua replicação do HIV no organismo leva à destruição dos linfócitos do tipo $\mathrm{T} \mathrm{CD}^{+}$, responsáveis pela imunidade do tipo celular, configurando o quadro de imunodeficiência característico da infecção pelo HIV e aids ( Marques e Masur 1999 ). Muitas vezes a infecção pelo HIV passa desapercebida, embora a deficiência da imunidade celular por ele causada seja determinante do surgimento de doenças que levam o paciente a buscar tratamento. As doenças infecciosas podem ocorrer por infecção exógena ou reativação de foco endógeno. $\mathrm{Na}$ fase sintomática inicial essas doenças são quase sempre tratáveis e o indivíduo pode voltar a ser assintomático novamente, após o correto tratamento da intercorrência.

Durante essa fase os indivíduos infectados levam vida normal, pessoal e profissional, submetendo-se a avaliação especializada quando necessária, ou seja, ao aparecimento de sinais e sintomas. O monitoramento da infecção pelo HIV é feita através de exames laboratoriais disponíveis na rede pública de saúde, de acordo com o Programa Nacional de DST/AIDS. A maioria das intercorrências pode ser tratada em regime ambulatorial e de hospital-dia, geralmente dispensando internações.

Como grande número de infectados desconhece seu estado, ou pretende ignorá-lo, é comum entre os pacientes pobres brasileiros - hoje a grande maioria dos acometidos pelo HIV/aids - que a sua infecção evolua naturalmente, até que a emergência de um quadro mais grave os force a procurar assistência médica, geralmente nos serviços de Pronto Socorro. Nesse momento, muitas vezes é feita pela primeira vez a suspeita da infecção pelo HIV. Outras vezes essa intercorrência é tratada sem que se dê conta da imunodeficiência subjacente, que continua seu curso.

Em sua evolução, a ação devastadora do HIV sobre o sistema de defesa torna o indivíduo infectado vulnerável à instalação de infecções, chamadas de oportunistas, e também de certas neoplasias. A aids propriamente dita é caracterizada quando o paciente apresenta um quadro de infecção avançada pelo HIV com repercussão severa em seu sistema imunitário, confirmado laboratorialmente ou indicado pelo quadro clínico. A definição de caso de aids tem variado ao longo dos anos e, de acordo com o conhecimento e recursos diagnósticos disponiveis, também varia ligeiramente entre os países. Vale lembrar que, por tratarse de uma síndrome, a aids apresenta-se de modo diverso entre os pacientes. A 
definição de caso de aids vigente atualmente no Brasil leva em conta a presença de sinais e sintomas causados pelo próprio HIV ou decorrentes de doenças oportunistas e neoplásicas, e/ou o diagnóstico de doenças indicativas de aids, segundo os critérios estabelecidos pelo Sistema de Vigilância Epidemiológica nacional. Evidência laboratorial de infecção pelo HIV e/ou de imunodeficiência também são consideradas para o diagnóstico, como também a menção de aids em declaração de óbito ( MS 1999 d).

As manifestações clínicas da aids variam de indivíduo para indivíduo, mas no início usualmente encontram-se sintomas constitucionais ( astenia, perda de peso acentuado, febre prolongada, diarréia crônica, adenomegalia ) e certas infecções como: pneumonias bacterianas, tuberculose pulmonar, herpes zoster, candidíase oral. As infecções oportunistas características da aids - pneumonia por Pneumocystis carinii ( PCP ), neurotoxoplasmose, infecção por Mycobacterium avium ( MAC ), moniliase de orofaringe, infecção disseminada por citomegalovírus ( CMV ), meningite por criptococos - aparecem mais tardiamente, quando o sistema imunológico estiver bastante comprometido ( Marques e Masur 1999). Neoplasias pouco comuns em indivíduos imunocompetentes costumam afetar esses pacientes, como o sarcoma de Kaposi e os linfomas. As manifestações neurológicas da aids são freqüentes, devidas ao HIV ou a infecções secundárias, acometendo tanto o sistema nervoso central como o periférico. O complexo cognitivo motor ligado ao HIV-1, que pode levar a um quadro de demência, ocorre na fase avançada da aids, enquanto as neuropatias periféricas, freqüentes causas de dor e dificuldades motoras, podem ocorrer em várias fases da doença (Oliveira et al. 1999).

Importante lembrar que o curso da aids é imprevisível: tanto sua velocidade de progressão quanto número de intercorrências são bastante variáveis entre os individuos afetados. Não é incomum o aparecimento nos hospitais especializados, de pacientes em fase avançada da doença, após um longo período completamente assintomático, como também daqueles individuos que permanecem durante muitos anos sofrendo de complicações constantes, e ainda, de doentes que apresentam evolução extremamente curta da aids, sem que se possa saber, com exatidão, a que se devem essas diferenças. 
O tratamento da aids é complexo e requer conhecimento especializado por parte do médico, devido às interações medicamentosas e alta toxicidade das drogas. Requer controle laboratorial sofisticado, com realização de exames especiais como a medida da carga viral e dos linfócitos do tipo CD4, em tempos regulares. Mas é feito ambulatorialmente, uma vez que diminui consideravelmente a ocorrência de doenças oportunistas e outras complicações, como já referido. Segundo Nadler, " $a$ introdução do tratamento anti-retroviral depende do curso provável ou observado da doença, da vontade do paciente em aderir ao tratamento e da disponibilidade de recursos terapêuticos" ( Nadler 1999, p. 338 ). Recomenda-se também a realização de profilaxia medicamentosa para algumas doenças oportunistas comuns na evolução da aids, principalmente daquelas que apresentam alta morbidade e/ou mortalidade, como a pneumocistose e a infeç̧ão disseminada pelo complexo Mycobacterium avium. Profilaxia secundária ou tratamento de manutenção, para evitar novos surtos, são recomendados após a ocorrência de pneumocistose e infecção pelo citomegalovírus.

Os recursos terapêuticos hoje disponíveis, tanto para o tratamento específico da aids, como para a profilaxia e tratamento das doenças oportunistas mudaram sensivelmente o perfil de morbidade e a mortalidade da aids, nos últimos anos. Isto é, as novas drogas conseguem diminuir a ocorrência e gravidade das intercorrências e deter a progressão da doença, embora ainda não consigam realizar a sua cura ( Hogg et al. 1997, Detels et al. 1998, Palella et al. 1998 ). O tratamento específico da aids com combinação de anti-retrovirais potentes ( chamado de HAART - highly active anti-retroviral therapy - na literatura médica internacional ) faz diminuir a carga viral circulante e aumentar os níveis de células T CD4+ no organismo, isto é: ataca o vírus e restabelece a imunidade do paciente. No entanto, essas drogas apresentam limitações importantes, já bem observadas, que impedem sua utilização generalizada. São elas: efeitos secundários bastante nocivos ao organismo, chegando até a óbito; posologia que requer a ingestão de múltiplos comprimidos várias vezes ao dia, em condições especiais; desenvolvimento de resistência ou "escape" da ação após um certo tempo de uso; baixa eficácia em caso de início tardio do tratamento. Além disso, o tempo de uso da terapia anti-retroviral necessário ao controle da doença ainda é desconhecido ( Condra 1998, Selwyn e Amold 1998 ). Uma conseqüência 
destas limitações é a existência de um grande contingente de pacientes para os quais, num dado momento, os recursos terapêuticos atualmente disponiveis ainda são insuficientes. Isto significa que, ao lado dos pacientes com doença bem controlada, existem muitos outros para os quais tanto a cura como o controle da doença são improváveis, mesmo não se levando em conta o altíssimo custo financeiro desse tratamento. Vale lembrar que no Brasil o tratamento da aids é proporcionado pelo sistema público de saúde a todos os doentes, gratuitamente, sem distinções.

$\mathrm{Na}$ fase avançada da doença, caracterizada por deterioração progressiva do estado geral, quando a imunodeficiência evolui a despeito da terapia instituída, os doentes geralmente apresentam vários episódios agudos de intercorrências, a maioria das vezes requerendo assistência hospitalar. Doenças respiratórias são freqüentes. A dependência de cuidados é comum, devido a debilidade geral e a afecções neurológicas comprometendo a locomoção. Dificuldades visuais decorrentes de retinite por $\mathrm{CMV}$, distúrbios cognitivos e quadro demencial podem ocorrer. Sintomas comuns incluem fraqueza, anorexia, náusea, vômitos, emagrecimento, febre, tosse, diarréia, prurido, dor, mal estar geral. $O$ tratamento médico nesse estágio deve procurar equilibrar o controle possível dos sintomas e de condições crônicas, curando as afeç̧ões responsivas aos medicamentos, tomando-se o cuidado para evitar procedimentos invasivos que potencialmente não tragam benefícios ao doente. O tratamento sintomático é essencial ( Wood et al. 1997 ). Em geral, os esquemas de medicação profilática devem ser mantidos, exceto quando se mostrarem ineficazes ou apresentarem efeitos colaterais que justifiquem sua suspensão, ou o paciente estiver bem próximo da morte (Welsby e Richardson 1995 ).

Estudos mostram que a dor é freqüentemente sub-diagnosticada e insuficientemente tratada nos pacientes com aids, incluindo um estudo realizado no I.I.E.R. ( Breitbart et al. 1999, Aires et al. 1999 ). A dificuldade de avaliação e controle da dor deve-se não apenas à sua subjetividade, mas também, no caso da aids, à falta de conhecimento dos clínicos e infectologistas sobre esse tratamento, à multiplicidade de patologias e medicações coexistentes e, no caso de usuários de drogas, ao medo de se estar contribuindo para a adição. ( O’Neill and Alexander 1997, Breitbart et al. 1999) 
A depressão que às vezes acompanha pacientes enfrentando doenças graves também costuma surgir na evolução da aids, como os estados psicológicos reacionais ao sofrimento intenso ( negação, raiva, etc. ). Problemas familiares e sociais também podem ser uma grande fonte de angústia e ansiedade para os pacientes, em qualquer fase da doença, e não devem ser esquecidos durante os períodos de internação. Muitos pacientes portadores de aids carregam o estigma associado à orientação homo/bissexual, ou ao uso de drogas ilícitas, práticas responsáveis pela transmissão da doença e não aceitas socialmente. Muitos têm seu estilo de vida revelado a familiares e conhecidos quando ocorre uma internação hospitalar, aumentando a carga de estresse desse evento. A imensa maioria dos doentes é composta de adultos jovens, muitos com filhos ainda pequenos, cuja possível orfandade traz angústia a todos os envolvidos, pacientes e familiares. Vários pacientes com aids já vivenciaram o luto por seus companheiros ou outros familiares, e carregam muitas carências, dores e medos ( Wood et al. 1997 ). Junto à dor física, as dores mental, social e espiritual compõem a "dor total", descrita por Dame Cicely Saunders ( Saunders e Baines 1983 ). Todas essas causas de sofrimento precisam ser diagnosticadas e consideradas durante o tratamento do paciente com aids, e não apenas aquelas decorrentes da ação direta do vírus em seu organismo. Daí a grande importância do trabalho conjunto da equipe multiprofissional, integrando os atendimentos médico especializado, psicológico, do serviço social, da enfermagem, da nutrição, da terapia ocupacional e fisioterapia, e o atendimento espiritual, sempre que se fizer necessário.

Segundo Welsby e Richardson, os pacientes com aids em fase terminal geralmente experimentam uma carga extra de sentimentos de perda:

- Perda de relacionamento com amigos e familiares ( estigma, medo );

- Perda de identidade ( perda do status social, tornar-se "aidético" );

- Perda de controle (dependência, tratamento difícil e absorvente );

- Perda da expressão sexual ( restrições, inibições );

- Perda da imagem corporal ( perda de peso severa, Sarcoma de Kaposi );

- Perda dos filhos ( evitar gestação, crianças infectadas, futuros órfãos );

- Perda do estilo de vida ( perdas financeiras )

(Welsby e Richardson 1998 ). 
Todos esses sintomas e sofrimentos relacionados evidenciam o caráter multi-dimensional das necessidades desses pacientes: fisicas, mentais, sociais e espirituais, que precisam igualmente ser atendidas.

Aqui no Brasil os pacientes com aids em fase avançada são quase que invariavelmente levados aos hospitais, onde são internados para tratamento e/ou para a morte . Não apenas os serviços de atendimento domiciliar atualmente disponíveis ainda são insuficientes, como também existem grandes obstáculos à realização da assistência a pacientes graves nas suas residências. Entre outros: existe uma grande barreira cultural, tanto médica quanto da sociedade geral, que tende a valorizar o tratamento mais intensivo, em número e agressividade de procedimentos; existem dificuldades concretas para o deslocamento urbano de equipes profissionais e/ou do paciente, sempre que se fizer necessário; e principalmente, é imprescindível a existência de cuidadores bem treinados e disponiveis para que se possa manter o paciente grave bem cuidado em seu domicílio. Por isso, e pela ausência de outras estruturas assistenciais em nosso pais - tipo hospice, por exemplo - é para os hospitais que esses pacientes são levados, e é lá que a assistência à fase terminal costuma ser realizada.

A inexistência de medidas efetivas para o bloqueio da transmissão da aids leva ao surgimento constante de novos casos da doença; os econômicamente menos favorecidos, com menor acesso a serviços de saúde ( Acurcio e Guimarães 1996 ), já em fase avançada. Esses fatos, associado ao uso dos novos esquemas terapêuticos - que prolongam a sobrevida sem conseguir curar a doença - mantém alta a necessidade de serviços de atenção médica para os pacientes com aids ( Aalen et al 1998 ).

No Brasil, incluindo a região da Grande São Paulo, onde os pacientes com aids se concentram, são os serviços públicos de saúde que têm respondido, bem ou mal, às demandas dessa clientela, desde o início da epidemia, há cerca de 20 anos.

Em São Paulo, município que apresenta mais de 1/5 do total de casos de aids até hoje notificados no país ( $21,5 \%$ dos casos acumulados no país, de 1980 a Junho de 2000 ), o atendimento hospitalar aos doentes com aids tem se concentrado em uns poucos serviços públicos, tanto para atividades diagnósticas como para tratamento ( MS 1999/2000). 


\title{
IX - Caso: o doente com aids em fase terminal, no I.I.E.R.
}

\author{
A instituição:
}

O Instituto de Infectologia Emílio Ribas ( I.I.E.R.), hospital da Secretaria de Estado da Saúde, criado há pouco mais de um século para o tratamento de doenças infecto-contagiosas, tem desenvolvido, desde o aparecimento dos primeiros casos de aids no país, um papel fundamental no diagnóstico e tratamento dos doentes da região, e no controle da epidemia ( Camargo 1994 ).

Esta instituição, tradicional na região da Grande São Paulo e referência nacional para o tratamento de doenças infecciosas, recebeu os primeiros pacientes com aids do país em suas enfermarias, e hoje ocupa cerca de $62 \%$ de seus leitos com portadores dessa síndrome. Seus serviços foram responsáveis pelo atendimento a mais de 27000 portadores do HIV, desde 1982 ( IIER / SAMCCD 1984 - 2000).

$A$ aids trouxe mudanças substanciais às características da clientela e das práticas operacionalizadas nessa instituição. A sua população atendida, antigamente caracterizada pela faixa etária infantil e pelo acometimento pelas doenças agudas com altas taxas de cura, transformou-se em um contingente de adultos jovens, grave e cronicamente enfermos, com alta taxa de mortalidade. Com a mudança da morbidade de sua clientela, nos anos 80 , os períodos de internação se alongaram, os procedimentos tornaram-se bastante mais complexos, as reinternações, antes raras, passaram a ser freqüentes nesse hospital (Guerra et al. 1992 ).

A dificuldade para absorver toda a demanda por assistência dos pacientes com aids, muitas vezes colocou o I.I.E.R. em situações bastante conflituosas, haja vista aos corredores de seu serviço de pronto-socorro, lotados com macas em condições precárias, no final dos anos 80 , bem como à deplorável situação de instalação de seu serviço ambulatorial, em ínfimas condições de uso (Guerra 1993 ).

Com o passar do tempo, essa instituição foi se adaptando às novas necessidades apresentadas, formando seu pessoal para o atendimento aos pacientes, reformando sua estrutura física, adquirindo materiais e equipamentos, em meio a 
constantes limitações financeiras e políticas, recorrentes em sua história secular. Novas práticas, antes incipientes, foram sendo incorporadas, entre suas práticas tradicionais.

$\mathrm{O}$ advento da aids trouxe ao I.I.E.R. o empenho no tratamento ambulatorial, que recebeu reforço de recursos humanos e de área física, embora suas instalações, hoje, ainda sejam bastante insuficientes. Atualmente os serviços ambulatoriais do I.I.E.R. são prestados em três turnos diários de segunda a sexta-feira, com uma média de 1.880 atendimentos mensais ( IIER / SAMCCD, $1984-2000$ ).

No final dos anos 80 , propunha-se a criação de hospitais-dia no Brasil como forma de racionalização dos recursos, na assistência aos pacientes com aids ( Cordeiro 1988, Camargo 1994 ). Em 1986, o então chamado Hospital Emílio Ribas implantou o primeiro hospital-dia brasileiro para esse finalidade, em precárias condições de funcionamento, segundo a médica responsável por ele (Guerra 1993 ). Gradualmente esse serviço foi se adequando, e ampliando sua capacidade de atendimento, até tornar-se centro de referência e de treinamento nacional.

O serviço de hospital-dia do I.I.E.R realiza atualmente cerca de 890 atendimentos / mês ( IIER / SAMCCD 1984 - 2000). Conta com leitos para pacientes adultos e pediátricos e uma equipe profissional própria. Absorve em seus programas de atendimento aqueles que necessitam de assistência crônica, para procedimentos hospitalares que dispensem internação, além de prestar atendimentos eventuais a pacientes encaminhados de outros serviços do hospital. Atualmente os diagnósticos mais freqüentes entre seus pacientes em tratamento são: corioretinite por Citomegalovírus, neurocriptococose, pneumocistose. Quimioprofilaxia e uso de imunoestimulantes são realizados no hospital-dia, este último principalmente na população infantil. A preocupação desse serviço com qualidade de atendimento tem feito com que especial atenção tenha sido dada às queixas e sugestões dos seus usuários, o que o distingue dos demais serviços do próprio hospital. O hospital-dia do I.I.E.R. tem sido, desde há mais de uma década, sede de capacitação de profissionais de todo o país, dos cursos patrocinados pelo Ministério da Saúde.

Em Maio de 1995 foi criada no I.I.E.R. uma variante de atendimento domiciliar, conhecida como "Projeto de Atendimento Comunitário". Esta forma de 
atendimento é realizada por uma equipe multiprofissional, a pacientes residentes em duas instituições filantrópicas que albergam pacientes com aids ( domicilios coletivos, conhecidos como "Casas de Apoio"). A equipe multidisciplinar, constituída por médicos, enfermeiros, auxiliares de enfermagem, nutricionistas, assistentes sociais e escriturários, visita regularmente ( quinzenalmente) os pacientes de cada uma das Casas, realizando consultas, exames e outros procedimentos, além de orientar os cuidadores dos doentes. Procedimentos simples como administração de medicamentos e imunizações, curativos, coletas de material para exames, etc., são realizados domiciliarmente pela equipe visitadora. Com esse atendimento tem havido uma grande diminuição da ida dos pacientes assistidos ao hospital: queda de $60 \%$ ao serviço de emergência e de $30 \%$ ao ambulatório, segundo avaliações divulgadas por esse serviço ( [Anonymus] 2000). Apesar de existir, entre os participantes dessa equipe técnica, uma proposta de ampliação do Projeto de Atendimento Comunitário, essa modalidade de assistência tem sido oferecida a um restrito grupo de pacientes - em torno de 70 pacientes / mês, em virtude de restrições materiais, que impedem o seu funcionamento em maior escala.

Muito recentemente, em Julho de 1999, criou-se no I.I.E.R., uma equipe multiprofissional para dispensar cuidados paliativos a pacientes internados em suas enfermarias, sempre que solicitado pelo médico responsável pelo paciente, através de um pedido de inter-consulta, como referido no início deste texto, e sobre a qual voltaremos posteriormente ( IIER / CE 1999 ).

A epidemia de aids trouxe ao I.I.E.R., uma nova experiência: assistir à morte de adultos jovens, em suas enfermarias. Lidar com a morte, ocorrência que se tornou freqüente em suas enfermarias, no entanto, não foi objeto de capacitação formal de seus profissionais, nem de adequação estrutural e funcional dos serviços. Essa tarefa tem sido realizada às expensas de um bastante variável envolvimento individual com a questão, adequado ou não, em um aprendizado errático e solitário, com obstáculos materiais e impedimentos administrativos, em um processo muitas vezes bastante sofrido para todas as partes envolvidas, profissionais, doentes e familiares ( Camargo 1994, Guerra et al. 1992 ). 


\section{A ) Perfil do paciente}

\section{A. 1 ) magnitude:}

O número total ( ocorrência acumulada ) de pacientes com aids que veio a morrer nas enfermarias do I.I.E.R., de Janeiro de 1984 a Dezembro de 2000, é 7570. Embora a ocorrência dessas mortes tenha atingido seu maior índice em 1991 ( 774 óbitos ) registra-se ainda hoje um número expressivo delas: 326 óbitos em 2000. Destes, $\mathbf{3 1 8}$ foram mortes por aids, de pacientes adultos internados no hospital.

Não foram considerados, para esses cálculos, os óbitos de pacientes não internados, ou seja, os óbitos que ocorreram até 48 hs após a chegada do paciente ao hospital e que ocorrem, em sua imensa maioria, no Serviço de Pronto Socorro e Emergência. Cada óbito hospitalar corresponde a um individuo doente em fase terminal - quer essa fase tenha sido diagnosticada ou não - que procurou ou foi levado ao hospital em busca de assistência. A esse conjunto de pacientes agregam-se outros em fase avançada da doença, que dependendo da definição de terminalidade adotada, mais ou menos abrangente, também podem ser considerados em fase terminal, embora tenham saido vivos com alta hospitalar.

Embora se registre no I.I.E.R. a ocorrência de óbitos causados por doenças agudas, como: meningite, leptospirose, e em menor volume algumas mortes causadas por doenças crônicas, como: esquistossomose ou cirrose hepática devida a hepatite, a imensa maioria dos óbitos aí ocorridos se deve à aids ( em torno de $80 \%$, nos últimos 3 anos ). Do mesmo modo, o grande volume de ocorrências diz respeito a mortes de adultos ( 12 anos ou mais ), ${ }^{30}$ o que se torna mais acentuado no caso da aids ( 15 mortes infantis por aids em 1998, 8 em 1999, e 8 em 2000 ).

Os casos que interessam particularmente a este estudo, isto é, de óbitos de adultos internados no I.I.E.R., devidos a aids representam em média $89 \%$ do total de óbitos ( todas as faixas etárias, internados ou não ) devidos a aids, ocorridos no hospital no período estudado ( $1998-2000$ ).

\footnotetext{
${ }^{30}$ Embora as séries históricas de eventos (óbitos) resgistrados no I.I.E.R. considerem adultos os individuos com idade igual ou superior a 12 anos, englobando portanto os adolescentes, das 1714 internações de pacientes com aids ocorridas em 2000, apenas 20 internações ( 1, 16 \% ) são de pacientes com idade entre 12 e 19 anos.
} 
A magnitude dessas ocorrências tem se mostrado estável, recentemente: o número semestral de óbitos devidos a aids, de adultos ( 12 anos e mais ) internados no hospital no periodo 1998 - 2000 , pode ser visto no gráfico da figura 1 :

\section{Figura 1}

Número semestral de óbitos devidos a aids, de adultos internados no Instituto de Infectologia Emilio Ribas, São Paulo, de Janeiro de 1998 a Dezembro de 2000.

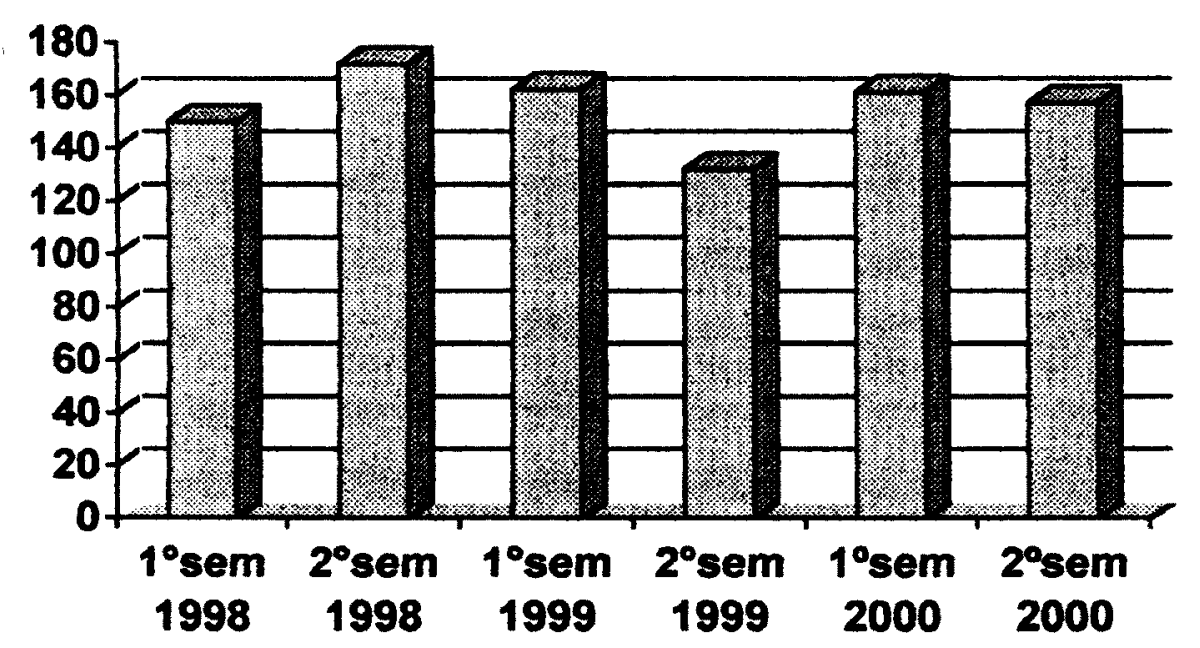

Fonte: Seção de Coleta e Classificação de Dados - S.A.M.C.C.D. / I.I.E.R. .

A grande maioria dos pacientes atendidos no I.I.E.R. provém do município de São Paulo. No ano de 2000, os óbitos por aids ocorridos nesse hospital contribuíram com 19,5\% ( 253 ) do total de óbitos ( 1300 ) registrados na capital, de residentes no município de São Paulo, segundo o Programa de Aprimoramento de Informações de Mortalidade do Município de São Paulo ( Pro-AIM).

O Pro-AIM também registra o local de ocorrência de óbitos: hospitalares, domiciliares e outros. Embora o número absoluto de óbitos causados pela aids venha diminuindo ao longo dos últimos anos, a proporção de óbitos hospitalares devidos a essa doença tem se mantido constante, no período estudado ( 1998 a 2000 ), em torno de 95,0 \% (95,0\% em 1998, 95,0\% em 1999, 96,0\% em 2000 ). Isto é, a quase totalidade dos pacientes com aids que morrem no município de São Paulo, 
residentes no município, morrem em instituições hospitalares. A proporção de óbitos domiciliares tem permanecido entre 3,7 ( 1998 ) e 2,9\% ( 2000 ). Alguns óbitos ocorreram em via pública ( em trânsito para o hospital ?), em outros locais ou em local ignorado.

Os registros de mortalidade por aids do Pro-AIM ajudam a visualizar algumas tendências da epidemia no município de São Paulo. O gráfico 2, a seguir, mostra a magnitude dos óbitos por aids em uma série histórica dos últimos 10 anos:

Figura 2

Número anual total de óbitos devidos a aids, de residentes no município, ocorridos no município de São Paulo de 1991 a 2000.

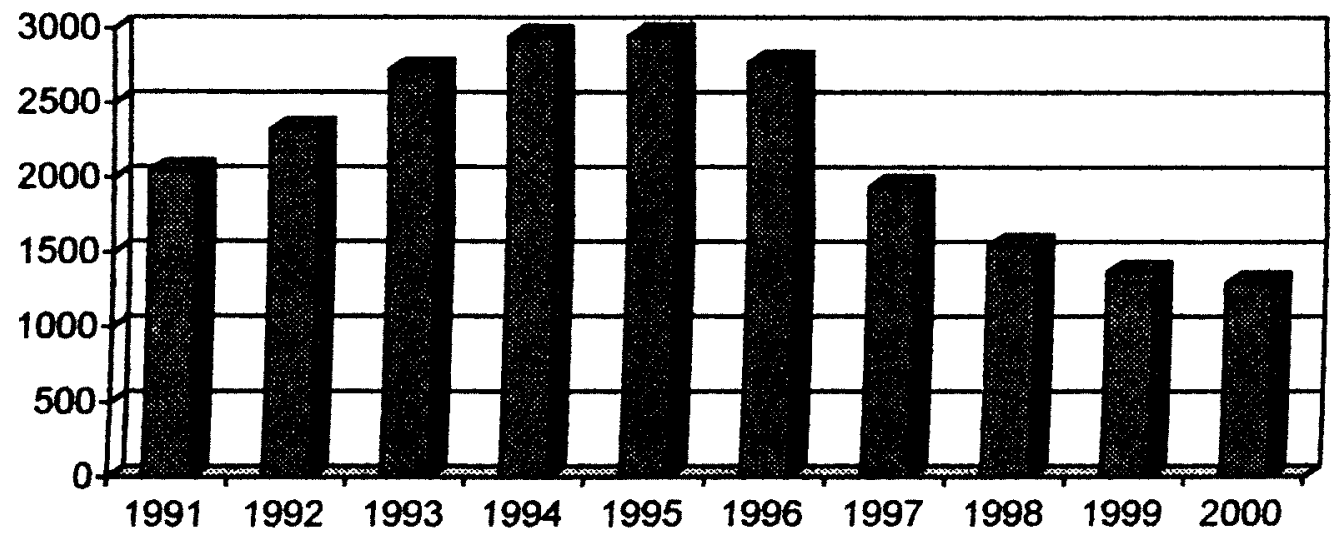

Fonte: Pro-AIM/ São Paulo: Prefeitura do Município de São Paulo; Março 2001.

Importante notar que a diminuiçăo do número de óbitos por aids verificada após a introdução de medicação específica mais potente nos esquemas terapêuticos ( a partir de 1996 ) vem apresentando uma desaceleração gradual e constante, ou seja, os gradientes vêm diminuindo:

queda de 30,0 \% no número de óbitos por aids do ano 1996 para 1997 , queda de $20,3 \%$ de 1997 a 1998 , queda de $11,7 \%$ de 1998 a 1999 , e queda de 4,8\% de 1999 a 2000. 
Mesmo observando-se que a epidemia de aids apresenta uma dinâmica bastante variável ao longo do tempo e que já tenha sido possível obter um grande impacto na redução da mortalidade por essa doença, o número de óbitos a ela devidos continua preocupante. No município de São Paulo a magnitude da mortalidade por aids ainda é alta. A média mensal de óbitos devidos a aids, no município de São Paulo ( excluídos os não residentes no município ) no período 1998 - 2000 foi de 117,2 (108,3 no ano 2000), para todas as faixas etárias.

No mesmo período - de Janeiro de 1998 a Dezembro de 2000, o Instituto de Infectologia Emílio Ribas apresentou média mensal de óbitos devidos a aids (entre pacientes residentes no município e outros ) de 27,2 para todas as faixas etárias, e 25,9 para adultos ( 12 anos e mais ), médias praticamente mantidas nos meses mais recentes.

\section{A . 2 ) perfil demográfico e epidemiológico:}

Serão apresentados os dados referentes ao conjunto de pacientes $(n=27)$ adultos que morreram devido a aids, no Instituto de Infectologia Emílio Ribas, no mês de Junho de 1999. Esses dados foram colhidos dos prontuários médicos. No ano de 1999 ocorreram 294 óbitos de adultos, devidos à aids, nessa instituição - segundo registros do Serviço de Arquivo Médico, Coleta e Classificação de Dados - dos quais o conjunto estudado representa $8,8 \%$.

A idade mínima encontrada foi 27 anos e a máxima 59. A idade média é de 36,6 anos ( desvio padrão 7,1), com mediana 35,0 e moda 33,0. Dois terços dos pacientes ( 18 ) se encontravam com idade entre 30 e 39 anos. 20 pacientes eram do sexo masculino $(74,1 \%), 7$ pacientes eram do sexo feminino $(25,9 \%)$.

Dos 21 pacientes $(77,8 \%$ ) para os quais essa informação foi registrada, 15 pacientes atingiram (completo ou não ) o primeiro grau $(71,4 \%)$ de escolaridade, 5 pacientes atingiram (completo ou não ) o segundo grau ( $23,8 \%)$; e apenas 1 paciente atingiu (completo ou não ) o nível superior ( 4,8\%). Registrou-se o estado civil em 23 casos ( $85,2 \%$ ). Destes: 13 pacientes eram solteiros ( $56,5 \%), 7$ eram casados $(30,5 \%)$; 3 pacientes eram separados, desquitados ou viúvos ( $13,0 \%$ ). 
18 pacientes residiam na capital $(66,7 \%$ ) e 9 pacientes residiam em outros municípios da região da Grande São Paulo ( $33,3 \%$ ). Do total, 4 pacientes $(15,4 \%)$ residiam em Casas de Apoio.

A distribuição segundo categoria de transmissão evidenciou: uso de drogas injetáveis: 10 pacientes ( $37,1 \%$ ); prática heterossexual: 6 pacientes ( $22,2 \%)$; prática homo / bissexual: 5 pacientes ( $18,5 \%)$; transfusão sangue: 1 paciente $(3,7$ $\%$ ); e categoria ignorada ou em investigação: 5 pacientes ( $18,5 \%$ ).

\section{A. 3 ) perfil de morbidade:}

Esses dados foram analisados para 26, do total de 27 pacientes ( um prontuário foi excluído por não conter essas informações ).

O número médio de diagnósticos foi de 3,7 por paciente, incluindo o motivo da internação e diagnósticos secundários ( mediana $=3,5$ e moda $=3$, mínimo $=1$, máximo $=6$ ). Os diagnósticos se referem apenas à internação em que ocorreu o óbito, não sendo computados doenças anteriores, não diagnosticadas novamente.

A doença de maior prevalência entre os pacientes falecidos foi a tuberculose, mesmo não tendo sido a causa básica de internação, tendo acometido 14 pacientes, ou seja $53,8 \%$ do total analisado. A caquexia foi uma condição mórbida bastante freqüente, atingindo também 14 pacientes ( $53,8 \%$ ). A monilíase oral ou esofágica atingiu 11 pacientes, ou $42,3 \%$ do grupo, a neurotoxoplasmose: 10 pacientes ( $38,5 \%) .3$ pacientes ( $11,5 \%$ ) apresentaram infecção disseminada por citomegalovírus ( CMV ) e também 3 pacientes ( $11,5 \%$ ) a pneumocistose. Herpes zooster, neurocriptococose e sarcoma de Kaposi foram diagnosticados em $2(7,7 \%)$ ou 1 paciente ( $3,8 \%$ ), apenas. Etilismo foi referido em 8 pacientes $(30,8 \%)$.

A prevalência de tuberculose encontrada entre esses pacientes é alta, como seria de se esperar, uma vez que ela freqüentemente encontra-se presente nesses pacientes por ocasião do diagnóstico da aids e apresenta tendência à recidiva nas fases de imuno depressão acentuada. Não foi possível comparar os resultados desta investigação com a morbidade na fase terminal da aids encontrada em outros estudos publicados recentemente devido a diferenças metodológicas. 
Quanto ao tempo referido de doença ( inclui a fase de infecção pelo HIV, com sintomas, e aids confirmada pelos critérios epidemiológicos ), a média de duração foi de cinco anos, porém com grande dispersão de valores ( desvio padrão = 5,2 anos ). O tempo mínimo de doença foi de alguns dias, o tempo máximo 17 anos; a mediana $=21 / 2$ anos e a moda 1 mês ( 3 casos ).

A seguir, a distribuição encontrada:

$$
\begin{array}{rlll}
\text { até } 2 \text { meses: } & 6 & \text { casos } & (23,1 \%) \\
3 \text { a } 6 \text { meses: } & 3 & \text { casos } & (11,6 \%) \\
7 \text { a } 11 \text { meses: } & 0 & \text { casos } & (0,0 \%) \\
1 \text { a } 5 \text { anos: } & 7 & \text { casos } & (26,9 \%) \\
6 \text { a } 10 \text { anos: } & 5 & \text { casos } & (19,2 \%) \\
>10 \text { anos: } & 5 & \text { casos } & (19,2 \%)
\end{array}
$$

$63,0 \%$ dos pacientes estudados ( $17 / 27$ ) estava sendo admitido no Instituto de Infectologia Emílio Ribas para tratamento da aids ou de intercorrências, em qualquer regime, pela primeira vez. Destes, 6 pacientes já apresentavam a doença há mais de 1 ano, tratando-se em outros serviços, ou não. Os 10 pacientes ( $37,0 \%$ ) com contato prévio com a instituição contavam com seguimento ambulatorial ou no hospital-dia, de duração variando de 5 meses a 11 anos, com ou sem episódios anteriores de internação.

A duração da internação dos pacientes que vieram a falecer no hospital foi bastante variável, com um mínimo de 1 a um máximo de 82 dias. A média foi de 23,9 dias, com desvio padrão de 20,7 dias. A mediana foi de 19,0 dias e a moda 3 dias ( 4 casos ).

A seguir a distribuição: $\quad 1$ a 7 dias: 9 pacientes $(33,3 \%)$

8 a 30 dias: 8 pacientes $(29,7 \%)$

$>30$ dias: 10 pacientes $(37,0 \%)$

A média de permanência registrada pelo Serviço de Arquivo Médico, Coleta e Classificação de Dados para os doentes com aids - todos - para esse mês ( Junho 1999 ) foi de 19,8 dias. 
Quase dois terços dos 23 pacientes para os quais havia se registrado informação sobre internações prévias estava vivendo sua primeira internação no Instituto de Infectologia Emílio Ribas para tratamento da aids ou de intercorrências, incluindo 3 pacientes que tinham tempo de doença superior a 10 anos. As referências a internações em outros locais eram incompletas, ou inexistentes. Segue-se a distribuição encontrada:

N. ${ }^{\circ}$ de internações anteriores no I.I.E.R.: $0: 14$ pacientes $(61.0 \%)$;

$$
\begin{array}{r}
1: 4 \text { pacientes }(17,4 \%) ; \\
2: 1 \text { paciente }(4,3 \%) ; \\
3 \mathrm{e}+: 4 \text { pacientes }(17,3 \%) .
\end{array}
$$

Dos dados obtidos, depreende-se que o paciente adulto em fase terminal de aids, comumente encontrado nas unidades de internação do hospital é um paciente do sexo masculino, de trinta e poucos anos, solteiro, de escolaridade baixa ( $1^{\circ} \mathrm{grau}$ ), procedente da capital. A categoria de transmissão mais provável é heterossexual ou uso de drogas injetáveis. Seu tempo de doença é indeterminado e foi recentemente matriculado no I.I.E.R.. Muito provavelmente está vivendo sua primeira internação hospitalar e tem como diagnósticos: tuberculose, caquexia, moniliase oral. Permanece internado por um período variável, recebendo inúmeras medicações e sendo submetido a múltiplos procedimentos, diagnósticos e terapêuticos.

\section{B ) Perfil da assistência prestada no I.I.E.R.}

\section{B . 1 ) Perfil profissional:}

Os resultados mostrados a seguir foram obtidos na primeira fase do estudo, a partir das respostas dos profissionais ao questionário proposto. (Anexo B )

62 profissionais responderam às questões formuladas - de um total de 118 que preenchiam os critérios de inclusão - todos eles de nível universitário e prestando assistência direta a pacientes internados, assim distribuidos: 
Tabela 2:

Participantes do estudo - número e proporção percentual segundo a categoria profissional. São Paulo, I.I.E.R., 1998.

\begin{tabular}{|l|c|c|c|}
\hline & Participantes & Existentes & $\%$ \\
\hline Assistentes sociais & 6 & 7 & $(85,7)$ \\
\hline Enfermeiros & 14 & 50 & $(28,0)$ \\
\hline Médicos & 38 & 55 & $(69,1)$ \\
\hline Psicólogos & 4 & 6 & $(66,6)$ \\
\hline
\end{tabular}

Algumas caracteristicas do grupo de profissionais que participou do estudo:

- poucos enfermeiros participaram do estudo;

- a idade dos profissionais pesquisados, de todas as categorias, se concentra na faixa etária dos 30 aos 49 anos ( 73,7\% dos médicos; 76,9\% dos enfermeiros; $100 \%$ das assistentes sociais e $100 \%$ dos psicólogos ), com idade mínima de 22 anos ( 1 enfermeira ) e máxima 61 ( 1 médico );

- todas as assistentes sociais são do sexo feminino; os enfermeiros se compõem de uma minoria masculina ( $15,4 \%$ ); os psicólogos se distribuem igualmente entre ambos os sexos; e os médicos têm maioria masculina ( $63,2 \%$ );

- quanto ao tempo de trabalho no I.I.E.R., $100 \%$ dos psicólogos investigados trabalham nessa instituição há 6 anos ou mais, como $2 / 3$ das assistentes sociais, e também $78,9 \%$ dos médicos, grupo que conta com 9 profissionais ( $23,7 \%$ ) com mais de 20 anos "de casa"; de modo diverso, os enfermeiros com 6 anos ou mais representam $38,5 \%$ do total, a mesma proporção de profissionais recém admitidos ( 1 ano ou menos de trabalho no I.I.E.R.);

- todas as categorias profissionais referem grande freqũência de atendimento a doentes em fase terminal, em suas práticas diárias ( $>75 \%$ ), como esperado;

- referem pouca ou nenhuma facilidade para o desempenho dessa atividade atender pacientes em fase terminal: $50 \%$ dos psicólogos, $40 \%$ dos médicos e das assistentes sociais; e 33,7 dos enfermeiros. 
A assistência prestada aos pacientes internados no I.I.E.R. foi avaliada pelos participantes da pesquisa, tanto para o atendimento aos pacientes em geral, como para os pacientes em fase terminal, através de notas ( de 1,0 a 5,0):

Tabela 3

\section{Avaliação dos profissionais ( nota de 1,0 a 5,0 ) sobre o atendimento prestado aos pacientes adultos internados para tratamento no I.I.E.R.}

Nota média $\mathrm{p} /$ atendimento geral

Assistentes sociais

Enfermeiros

Médicos

Psicólogos
3,7

4,5

3,8

3,5
Nota média $\mathrm{p} /$ atendimento a paciente em fase terminal

2,7

4,1

3,2

3,7

A análise de variâncias ( teste de Kruskal-Wallis ) mostrou que os subgrupos compostos pelas categorias profissionais médicos e enfermeiros diferem entre si, no que se refere às notas atribuidas ao atendimento geral prestado no I.I.E.R, diferença estatisticamente significante com $95 \%$ de confiança: $p=0,006$. A análise das variâncias entre os demais grupos não é viável devido ao pequeno número de casos em cada um deles. Também para as notas atribuídas à assistência a pacientes em fase terminal, as variâncias observadas entre os subgrupos de médicos e de enfermeiros são não homogêneas ao teste de Kruskal-Wallis: $p=0,012$, significando diferentes avaliações por parte desses subgrupos profissionais.

Percebe-se que os enfermeiros foram os que melhor avaliaram a assistência prestada, tanto a pacientes internados em geral, como a pacientes em fase terminal. Nesse grupo também se encontrou o maior número de profissionais recentemente admitidos na instituição. ( $38,5 \% 1$ ano ou menos ) Essa categoria profissional foi também a que menos participou da pesquisa, existindo baixa representatividade do conjunto dos enfermeiros da instituição no estudo. Esta reduzida participação talvez se deva ao não contato direto da pesquisadora com grande parte desses profissionais, devido a seus vários níveis de subordinação hierárquica e diversos turnos de trabalho, ocorrendo a transmissão de informações pelo intermédio das respectivas chefias. 
A nota mais baixa atribuida ao atendimento pelas assistentes sociais talvez se deva parcialmente à dependência de recursos extra-institucionais ( família, sociedade ) para a realização do seu trabalho, recursos estes bastante escassos na grande maioria dos casos. As discussões na segunda fase do trabalho corroboram, em parte, essa hipótese.

Quanto à avaliação da assistência em geral, obteve-se nota acima do ponto médio ( 3,0$)$ em todas as categorias profissionais, com nota média geral ( média do total de notas ) $=3,9$. A avaliação da assistência aos doentes em fase terminal resultou em nota média um pouco menor: 3,4 , com um grupo profissional tendo atribuído nota média inferior a 3,0.

Chama a atenção a faixa etária dos profissionais ser bastante semelhante à dos pacientes assistidos, como também a alta aderência dos funcionários à instituição, com grande número daqueles que se dizem "antigos". O longo tempo de trabalho na instituição, no entanto, não se fêz acompanhar de "facilidade" para lidar com os pacientes em fase terminal, indicando que essa habilidade não é adquirida apenas por maior número de experiências.

Embora a quase totalidade dos profissionais pesquisados relate grande freqüência de atendimento a doentes em fase terminal em suas práticas cotidianas, cerca de $40 \%$ deles - incluindo profissionais das diversas categorias - refere pouca ou nenhuma facilidade para o desempenho desta função.

Análise das avaliações, sugestões e propostas dos profissionais:

Os resultados obtidos nas duas fases da pesquisa serão apresentados e analisados em grupo, de acordo com as categorias profissionais. O material críticas, observações e sugestões - colhido na primeira fase do estudo não difere do obtido na segunda fase. Também a composição média dos grupos é a mesma, exceto para a categoria médica, em que na segunda etapa optou-se por trabalhar com um grupo menor, formado pelos supervisores das unidades de internação, em função da metodologia de pesquisa escolhida ( grupo focal ). O intervalo de um ano entre a realização das duas etapas da pesquisa permitiu a confirmação das condições estruturais em que se dá a assistência aos pacientes, bem como a verificação de um 
discreto movimento de pequena parte dos profissionais, no sentido da busca de melhor capacitação técnica ou adequação para o desempenho de suas atividades.

\section{$>$ Assistentes sociais:}

Esse grupo participou ativamente das duas fases do estudo, comparecendo com um maior número de profissionais à discussão temática ( em comparação à fase anterior ), apresentando e discutindo suas experiências, críticas e sugestões. Uma peculiaridade desse grupo é a sua atividade junto a familiares dos pacientes e a instituições de apoio social. Outra, é o seu modo de funcionamento, que propicia o compartilhamento das experiências profissionais individuais. Duas assistentes sociais participavam da Equipe de Cuidados Paliativos em 1999. A sugestão desse grupo para melhorar o atendimento ao doente em fase terminal no I.I.E.R. é a realização de amplo debate sobre o tema, envolvendo todos os profissionais, seguido de treinamentos e trabalho em equipes multiprofissionais. Pode ser exemplificada na fala: "Envolver as chefias todas; desenvolver uma consciência institucional." Entre as dificuldades listadas, ressaltam dificuldades emocionais ( sentimentos de pena, inadequação, raiva ), despreparo técnico ( falta de reciclagem, supervisão [... "cada um cava como pode"] ), problemas estruturais internos ( rigidez institucional, falta de integração do trabalho multiprofissional ) e falta de recursos na sociedade ( cuidadores domiciliares, Casas de Apoio ).

\section{$>$ Enfermeiros:}

Esse grupo teve uma pequena participação na primeira fase do estudo, conforme já visto, e apenas uma reunião com as chefias, na segunda fase. $\mathrm{Na}$ discussão temática contou-se com boa participação, embora poucas sugestões tivessem sido apresentadas. Em termos gerais, o tema foi reconhecido como importante. Dentre as sugestð̃es recolhidas na primeira fase do estudo, citam-se: "melhorar $a$ qualificação dos profissionais", "dar apoio psicológico aos pacientes, melhorar a condição de trabalho dos funcionários".

\section{Médicos:}

Os médicos contribuíram com muitas sugestões, críticas e observações, em ambas as fases do estudo. A questão chave para essa categoria profissional é a 
definição de terminalidade, ou critérios para o abandono do tratamento curativo, e sua base legal. Esses profissionais referiram a necessidade de aprofundar a discussão sobre os aspectos éticos e legais envolvidos na assistência ao doente na fase terminal, mas também a falta de diretrizes técnicas a respeito da interrupção da terapia anti-retroviral, quando o doente parece não mais se beneficiar dela. $O$ atendimento a pacientes nessa fase foi referido como emocionalmente difícil por parte deles ("extenuante, desgastante") mas sem problemas pela maioria. A falta de tempo para participar de palestras e discussões teórico-práticas também foi lembrada por alguns, como também a falta de espaço e de recursos materiais variados. A seguir, algumas sugestões e depoimentos, tais como registrados pelos pesquisados, em seus formulários:

"Estudar mais os métodos existentes. Montar equipe multiprofissional de cuidados paliativos. Treinamento constante, suporte psicológico."

"Necessidade de incrementar o atendimento domiciliar em nosso meio."

"Maior treinamento para humanizar o atendimento a doentes terminais."

“A familia deveria poder acompanhar o paciente grave e terminal durante 24 horas. Programas de terapia ocupacional para adultos, principalmente os com aids e internações prolongadas. Atendimento psicológico para todos os familiares de pacientes HIV internados. Maior compromisso no relacionamento médico-paciente. Que o paciente ambulatorial possa ser internado na enfermaria com o seu respectivo médico. Resgatar a ética médica (em falta nesse serviço)." “A frustração é não poder ajudar mais o paciente e não conseguir uma casa de apoio."

"Qual a hora de parar? Qual o jeito digno de morrer?"

$>$ Psicólogos:

Os psicólogos participaram em ambas as fases da pesquisa. Manifestaram preocupação com a qualidade de vida do paciente e relataram as dificuldades encontradas para o desempenho de seu trabalho: pouca integração das equipes multiprofissionais, inadequação do espaço para o trabalho nas enfermarias, com pacientes e familiares ( falta privacidade ) e ainda: falta de reflexão coletiva 
sobre as dificuldades comuns do trabalho. Esse grupo - pequeno - encaminhou poucas sugestões, dentre as quais a realização de grupos de estudo multiprofissionais para discutir temas ligados à assistência ao doente em fase terminal. Na discussão temática ( 1999 ) três psicólogos referiram ter participado recentemente de palestras ou cursos relacionados ao tema em foco e duas psicólogas participavam da Equipe de Cuidados Paliativos, uma das quais já vinha desenvolvendo um trabalho relacionado à temática da terminalidade desde há vários anos.

Como se depreende das falas apresentadas, os profissionais entrevistados de todas as categorias - envolvidos com a assistência direta aos pacientes, em qualquer fase de suas doenças - contribuíram bastante para o aclaramento da problemática da assistència ao doente em fase terminal no I.I.E.R., debatendo sua experiência, indicando dificuldades principais encontradas em seu cotidiano, como também apontando soluções para algumas questões. A idéia central dos discursos é a necessidade de melhorar a capacitação dos profissionais para esse trabalho, como também as suas condições de atuação. Em outras palavras, é possível distinguir em suas falas, duas ordens de questões, que são: $1^{\circ}$ ) falta de preparo técnico ou de conhecimento especializado, pontual ou geral, e de preparo emocional para desempenhá-lo; $2^{\circ}$ ) dificuldades operacionais institucionais, quer devidas a normas pouco flexíveis, quer devidas ao modo de funcionamento e relacionamento entre os vários profissionais. Questð̃es culturais e falta de recursos internos e externos à instituição também foram lembrados, embora com menor ênfase. Muitos desses profissionais estavam se empenhando ativamente na busca de soluções para os problemas relatados, alguns já atuando na instituição há vários anos, como a psicóloga de uma das unidades de internação que coordena grupos de discussão com internos, estagiários e profissionais de sua enfermaria, sobre a assistência a pacientes em fase terminal. ${ }^{31}$ Outros, foram encontrados, na segunda fase do estudo, atuando

31 Essa psicóloga, responsável pelo treinamento de estagiários de Psicologia no I.I.E.R, tem contado também com a assessoria de uma das pioneiras no campo da Tanatologia - formada com E.KüblerRoss - no Brasil, prestando serviços voluntários ao hospital. 
junto à recém-criada Equipe Multiprofissional de Cuidados Paliativos do I.I.E.R. Os discursos dos profissionais ligados à assistência direta aos pacientes trazem uma crítica ao trabalho atualmente realizado: apontam falhas, dificuldades; mas também demonstram esforços individuais para superá-los e indicam saídas e soluções - até apelos - para a melhoria da assistência a pacientes em fase terminal na instituição.

Equipe Multiprofissional de Cuidados Paliativos:

A Equipe Multiprofissional de Cuidados Paliativos do I.I.E.R. começou suas atividades em Julho de 1999. A iniciativa surgiu do encontro de vários trabalhadores desse hospital interessados na melhora da qualidade da assistência aos pacientes fora de recursos terapêuticos de cura, após uma palestra sobre o tema, ministrada por um professor convidado, em Junho de $1998 .{ }^{32} \mathrm{O}$ grupo, coordenado por uma médica infectologista com especialização em controle de dor ( Dra. Elisa M. Aires ), conta com profissionais de várias categorias: médicos, enfermeiras, assistentes sociais, nutricionistas, psicólogos, terapeutas ocupacionais, auxiliares de enfermagem, farmacêutico e voluntários das capelanias religiosas do hospital. Este conjunto de trabalhadores do I.I.E.R. dispôs-se, voluntariamente, a prestar cuidados paliativos aos doentes em fase avançada ou terminal e a pacientes com sintomatologia de dificil controle, como dor, internados no hospital ( IIER/CE 1999 ).

Para realizar essa função o grupo buscou apoio interno - direção técnica, chefes e colegas - e também externo - assessoria técnica de especialistas ou de profissionais mais experientes. A Equipe de Cuidados Paliativos do I.I.E.R. vem se capacitando através de discussão de casos, palestras e treinamentos, muitas vezes com o apoio de técnicos e especialistas de outras instituições. Os atendimentos, reuniões de equipe ( para discussão de caso, troca de informações, resolução de questões burocráticas ) treinamentos e demais atividades de cuidados paliativos são realizados em horário adicional à jornada oficial de trabalho de cada um, já que os

32 Dr. Marco Túlio de Assis Figueiredo, responsável pelo Curso de Tanatologia ( Extensão de Graduação ) da Universidade Federal de São Paulo - Escola Paulista de Medicina e membro do Conselho Diretor da International Association for Hospice \& Palliative Care (Web site: http// www. hospicecare.com ) 
componentes do grupo continuam exercendo as funções regulares para as quais foram contratados ( IIER / CE 1999).

$\mathrm{O}$ atendimento em cuidados paliativos é prestado pela equipe a pacientes internados, sempre que solicitado pelo profissional responsável pelo doente, em regime de inter-consulta especializada. A atuação é multiprofissional e integrada à assistência recebida pelo paciente em sua enfermaria. Também envolve os familiares ou outros cuidadores do doente ( IIER / CE 1999 ).

O Relatório de Atividades do ano de 1999 da Equipe Multiprofissional de Cuidados Paliativos do I.I.E.R. refere ter realizado 38 atendimentos ( dor, sedação terminal, etc. ), a 33 pacientes ( 30 com aids ) no período Julho-Dezembro 1999. Entre as dificuldades arroladas está o não acompanhamento dos pacientes após a alta hospitalar, ou à reinternação em outra unidade que não aquela que solicitou o atendimento. A falta de diretrizes para condutas médicas eticamente orientadas, como a interrupção de tratamento curativo, também foi citada. Outras se relacionam à pouca disponibilidade de familiares, cuidadores e Casas de Apoio comprometidos com o seguimento do doente, falta de medicamentos especiais e de recursos materiais (equipamentos para cuidados, espaço fisico, material de secretaria ), além da não disponibilização de membros da equipe para dedicação exclusiva a essa atividade. As metas para o ano 2000 envolvem: leitos próprios, acompanhamento ambulatorial, arsenal terapêutico, material de enfermagem, contato com familiares, flexibilização de horário de visitas e outras restrições impostas a pacientes, preparo de cuidadores, discussões éticas, aumento da carga horária dedicada a cuidados paliativos, atividades cientificas, divulgação do trabalho, treinamento, etc. Nesse relatório a equipe refere ter realizado um trabalho dificil, mas gratificante.

\section{B . 2 ) Perfil da administração:}

Em sua entrevista, o diretor técnico do I.I.E.R. referiu como grande prioridade da instituição, nesse momento, a ampliação e adequação do espaço físico destinado ao atendimento ambulatorial. Dentre as necessidades percebidas, 
considerou a grande importância de se prevenir a resistência às drogas antiretrovirais atualmente em uso, além do preparo técnico dos profissionais da instituição para atuar no controle e tratamento das doenças emergentes e reemergentes. Citou o atendimento comunitário iniciado em 1995 como um trabalho realizado com pequena despesa e grande retorno, que gostaria de poder expandir. A maior dificuldade na direção dessa instituição, segundo ele, é a falta de autonomia administrativa. $O$ diretor técnico mostrou-se receptivo à problemática da assistência ao doente em fase terminal, entendendo-a como um dos momentos da assistência global ao paciente. Reafirmou seu apoio ao trabalho da equipe multiprofissional de cuidados paliativos atuante no hospital. Lembrou, no entanto, a grande dificuldade da instituição para obter recursos para a implementação de novos projetos, como o atendimento domiciliar e a ampliação da área física do Instituto.

$O$ diretor administrativo do I.I.E.R. reafirmou a escassez de recursos financeiros do Estado, mesmo com demanda estável. Referiu a importância da criação de novas opções, com o envolvimento da comunidade na resolução dos problemas. Citou como exemplos o atendimento domiciliar e/ou comunitário e o hospital-dia, que prestam serviços de boa qualidade em sua esfera de atuação, ajudam a diminuir o "hospitalocentrismo", reduzem custos e riscos de infecção hospitalar. Para esse diretor, as prioridades do I.I.E.R. seriam: implantar o atendimento domiciliar e realizar uma padronização terapêutica - medicamentosa e de procedimentos - de modo a atualizar tecnologicamente o hospital ( " os médicos ficam reféns da propaganda de insumos"), evitar desperdícios e manter diversidade com qualidade. $\mathrm{O}$ diretor administrativo do I.I.E.R. mostrou-se sensível à problemática da assistência ao doente em fase terminal, considerando-a uma questão pertinente à assistência médica. Segundo esse diretor, a grande dificuldade para a introdução de novas práticas seria de ordem cultural, devida tanto à onipotência médica quanto à pouca noção de cidadania dos pacientes. $O$ diretor administrativo lembrou ainda uma questão importante na administração de recursos financeiros do hospital, relacionada à assistência a pacientes com aids em fase terminal: o reembolso autorizado pelo sistema SIH-SUS tem prazo máximo de internação, e não cobre os custos da terapia curativa ministrada - no caso, os medicamentos anti- 
retrovirais de altíssimo custo. Dessa forma, a identificação do paciente como estando em fase terminal levaria à suspensão do pagamento das drogas de finalidade curativa utilizadas, o que torna essa assistência inviável economicamente para a instituição. ${ }^{33}$

O Coordenador dos Institutos de Pesquisa ( C.I.P. ) primeiramente delimitou a esfera de atuação da Secretaria de Saúde: nem centro decisório do governo, nem centro decisório da sociedade, mas sim um órgão estatal com poder de alocar recursos na área da saúde, atendendo a necessidades historicamente definidas. $O$ coordenador referiu a constante insuficiência de recursos e a pouca flexibilidade institucional para mudar a sua destinação, lembrando que "para fazer o novo é preciso manter o sistema em uso." Apesar da dificuldade para a implantação de novos projetos - "tem que ter receita própria para o novo" - o coordenador lembrou a atuação de "atores com vinculos com o poder, que criam espaços para suas propostas, através de um espontaneismo voluntarista". As prioridades da Secretaria de Saúde seriam, nesse momento: melhorar a atenção básica, com ênfase no atendimento comunitário; montar redes de atendimento com segmentação da clientela, sistemas de referência e quadros bem preparados; e mudança do enfoque, do individual para o social. O coordenador da C.I.P. não abordou especificamente a questão da assistência ao paciente em fase terminal, referindo esses pacientes como um dos segmentos da clientela que demanda assistência, cujas necessidades se colocam frente a outras necessidades igualmente importantes ( "briga entre interesses diferenciados, não do bom contra o mau, mas do bom contra o bom"), cabendo ao setor de planejamento da Secretaria criar condições e possibilidade de materialização das propostas trazidas pelo processo decisório.

A idéia central que emerge das falas destes atores - todos eles dirigentes de serviços importantes na estrutura da Secretaria de Estado da Saúde de São Paulo - é a escassez de recursos para a execução de muitas ações igualmente necessárias. A preocupação com a execução das ações já programadas ressalta nos três discursos, deixando uma pequena margem para a criação e implantação de novos projetos. Mas

\footnotetext{
${ }^{33}$ Portaria Ministerial MS / SNAS 291, de 17 - 06 - 1992, publicada em Diário Oficial da União de 23-06-1992, p. 7901, que inclui o tratamento a pacientes terminais na lista de procedimentos do SUS.
} 
todos eles mostraram-se abertos para ouvir e até mesmo acolher uma nova proposta. mostrando-se receptivos à questão da assistência ao doente em fase terminal, principalmente os diretores do próprio I.I.E.R., que já vinham apoiando a atuação da equipe de cuidados paliativos no hospital. Os três diretores entrevistados apontaram o atendimento comunitário, em alguma de suas formas ( atendimento comunitário realizado nas Casas de Apoio pelas equipes do I.I.E.R., atendimento domiciliar, redes de atendimento com enfoque social ) como uma direção a seguir no equacionamento da assistência em saúde, em sua esfera de atuação.

\section{O Programa Nacional de DST/Aids:}

O Programa Nacional de DST/Aids tem entre suas funções a implementação e regulamentação da assistência aos doentes com aids, em qualquer fase de suas doenças. A assistência médica hospitalar faz parte de seus modelos de atendimento, desde o início da epidemia. A incorporação mais recente de outros modelos assistenciais, como hospital-dia e atendimento domiciliar, já no final dos anos 80 , inicialmente como projetos-pilotos, e em meados dos anos 90 como propostas claramente delineadas, propiciou a contemplação das diferentes necessidades dos pacientes, em cada momento de sua situação de doença. Mas foi particularmente o desenvolvimento do atendimento domiciliar terapêutico ( ADT), modalidade de assistência considerada inovadora e avançada à época de sua implantação, que conferiu aos doentes em fase terminal - e também a seus familiares e cuidadores - 0 explícito reconhecimento de suas necessidades, apesar das dificuldades encontradas.

Segundo o Guia de Procedimentos em DST/Aids na Assistência Domiciliar Terapèutica do Ministério da Saúde, "a concepção inicial da ADT adotada pelo Ministério da Saúde mostrou-se insuficiente em suas atribuições. (....) Nesse contexto, procedimentos e limites das intervenções terapêuticas foram sendo delineados gradativamente, na medida em que os projetos iam sendo implementados. (....) Apesar da fatalidade desses casos [ pacientes que vieram a óbito ], a realidade dos fatos ainda nos permite concluir que a equipe de ADT foi 
eficiente no devido suporte clínico e psicossocial a esses pacientes em fim de vida, bem como a seus familiares" ( MS 1999 b p. 22 ).

A ocorrência do óbito domiciliar, ou a prestação de cuidados a pacientes agonizantes em suas casas são situações de dificil manejo para os membros da equipe de saúde, não apenas pelas dificuldades técnicas e emocionais, mas também pela falta da "proteção" do ambiente institucional, segundo o mesmo Guia, podendo até "provocar questionamentos dentro da equipe, até uma decisão definitiva: continuar ou não dispensando assistência ao paciente nesse periodo final, quando a manutençao do equilibrio emocional e do bom desempenho da equipe torna-se mais dificil." ( MS 1999 b p. 23 ).

Supervisões do trabalho de atendimento domiciliar, realizadas pelo Ministério da Saúde em 1996 e 1997, identificaram grande diversidade de atuação entre os vários serviços, a falta de parâmetros normativos e despreparo profissional, dentre outros entraves ao bom funcionamento desse modelo assistencial ( disponível em: <http.//www aids.gov.br/assistencia/aids 1/relativ_alternativa. htm $>$ [ Fev. 2001])

Mais recentemente, a Coordenação do Programa Nacional de DST/Aids do Ministério da Saúde propôs-se a desenvolver atividades educativas em cuidados paliativos, para os profissionais de saúde envolvidos com esse programa. A técnica responsável pela sua Unidade de Assistência falou em nome do Ministério da Saúde em 13-04-00, a respeito dos cuidados paliativos na assistência a pacientes com aids, por ocasião da abertura do III Congresso Internacional de Cuidados Paliativos. Este evento foi realizado em São Paulo, de 13 a 15 de Abril de 2000, pela Associação Brasileira de Cuidados Paliativos. Em seu pronunciamento público representando a instituição referida, ela afirmou a importância da qualidade de vida dos pacientes, em qualquer fase de sua doença, com ou sem possibilidades de cura. Afirmou ainda que os cuidados paliativos constituiam objeto de atenção da Coordenação Nacional do Programa de DST/Aids, e anunciou formalmente a intenção institucional de desenvolver ações mais efetivas nessa área. Em Agosto de 2000 a Unidade de Assistência desse órgão reuniu um grupo de trabalho no Ministério da Saúde, dando início à elaboração de projetos para capacitação de pessoal em cuidados paliativos, com a participação da autora deste estudo. 


\section{B . 3 ) Perfil da assistência:}

A título de esclarecimentos, vale lembrar algumas normas e peculiaridades a que ficam sujeitos os pacientes internados no I.I.E.R., um hospital com 230 leitos, dedicado ao tratamento de doenças infecto-contagiosas. As unidades de internação ou enfermarias são providas de quartos com dois leitos, enquanto a Unidade de Terapia Intensiva e o Serviço de Pronto Socorro contam com quartos individuais. Visitas são admitidas em horário restrito - uma hora diária de segunda a sexta-feira, e duas horas diárias nos fins de semana - exceto quando liberadas pela equipe multiprofissional responsável pelo paciente, como já citado. Crianças visitantes são fortemente desencorajadas ou não permitidas; roupas e objetos pessoais, incluindo flores, bem como alimentos não fornecidos pela instituição, são em regra proibidos, requerendo negociações para autorização em caráter excepcional. Não se encontram cadeiras nos quartos, para uso dos visitantes ou acompanhante autorizado a pernoitar junto ao doente. O sistema de campainhas, para chamar o pessoal de enfermagem, encontra-se fora de funcionamento há alguns anos. Não se permite a circulação de pacientes fora de suas unidades de internação - onde aqueles pacientes não em isolamento podem andar no corredor, e assistir a televisão junto a outros doentes exceto quando acompanhados por funcionários autorizados. É proibido fumar nas dependências internas do hospital. Os pacientes podem receber visitas de voluntários das capelanias - de diversas denominações religiosas - e eventualmente participar de atividades religiosas ou recreativas oferecidas, dependendo de seu consentimento e de suas condições de participação, sempre avalizados pela chefia das enfermarias. Algumas organizações não governamentais que realizam atividades artísticas ou de lazer junto a pacientes, têm atuado no hospital, em conformidade com o disposto em cada unidade, trazendo palhaços, contadores de histórias e pintores às enfermarias. Numerosos estudantes e estagiários, de diversas formações na área da saúde - e de áreas afins, como voluntários das capelanias - circulam rotineiramente nas dependências do hospital, totalizando mais de 2000 ao ano.

A seguir, o relato da assistência prestada aos pacientes estudados, obtido de seus prontuários: 
Todos os pacientes foram assistidos por equipes multiprofissionais, conforme registrado em seus prontuários, com atendimento médico e de enfermagem sempre presentes. Pode-se encontrar o registro de atendimento pelo assistente social na imensa maioria dos casos estudados. $O$ atendimento por outros profissionais, como psicólogos e fisioterapeutas, e também por médicos de especialidades diversas - cirurgia, endoscopia, neurologia - também está registrado em vários prontuários. Embora a avaliação da terapêutica instituida para cada caso não faça parte dos objetivos deste estudo, vale mencionar que: as prescrições medicamentosas são extensas, em geral constando de 20 itens ou mais, com grande número de drogas de ação anti-microbiana ( antibióticos, anti-fúngicos, anti-retrovirais ), quase sempre administradas intravenosamente. Não foi feita uma avaliação do uso do "coquetel" de anti-retrovirais, devido à grande proporção de pacientes recém diagnosticados ou recém admitidos no I.I.E.R, isto é: em início de tratamento ou sem informações adequadas sobre o tratamento prévio. Da mesma forma, não se pôde estudar a evolução dos marcadores laboratoriais de progressão da doença - medidas de CD4 e de carga viral - embora se tenha encontrado um expressivo número de resultados de exames laboratoriais, de variados tipos, nos prontuários médicos dos pacientes.

Durante o período de internação seis pacientes ( $23,1 \%$ ) receberam tratamento na Unidade de Terapia Intensiva, uma paciente foi submetida a cirurgias de médio porte, até dois dias antes do óbito ( cirurgia abdominal exploratória e colostomia ) e 11 pacientes ( $42,3 \%$ ) foram submetidos a manobras de ressuscitação, alguns mais de uma vez, incluindo utilização de desfibrilador cardíaco e ventilação controlada. Foi registrada em um prontuário médico a opção pela não realização das manobras de reanimação cárdio-respiratórias, dadas as condições clínicas do paciente.

A dor foi registrada nos prontuários como queixa importante, quer pela persistência quer pela intensidade, na evolução médica de 7 pacientes ( $26,9 \%$ ), dois dos quais receberam medicação opióide ( Dolantina) episódica. Um paciente foi medicado com esquema de sedação terminal ( conhecido como " $M 1$ ").

Ansiedade, angústia e/ou depressão apareceram registradas nos prontuários de 10 pacientes ( $38,5 \%$ ). Solicitação enfática e/ou reiterada de alta foi registrada 
em 6 deles ( $23,1 \%$ ). Para um desses pacientes foi concedida a alta a pedido, que não se viabilizou ( não foram registrados os motivos ). Assistência especializada psicológica e/ou psiquiátrica - foi realizada em 7 casos ( $26,9 \%$ ), incluindo um caso em que também foi realizado atendimento a familiares.

Não se encontraram nos prontuários examinados quaisquer referèncias à liberação do horário de visitas ou autorização para permanència de familiares no quarto, durante o periodo de internação, embora alguma dessas situações possa ter ocorrido. Para um paciente encontrou-se menção a licença médica, para visita aos familiares no fim de semana ( duas vezes ), e para dois outros a licença foi concedida e posteriormente cancelada, devido a piora do quadro clínico do paciente.

Também não há registros nos prontuários da situação de isolamento em que se encontrava o paciente para fins de controle da infecção hospitalar, isto é, da obrigatoriedade ou não do uso de máscaras faciais, aventais e luvas quando da sua manipulação, embora se saiba que essas medidas são bastante freqüentes nesse hospital, mormente em pacientes com o padrão de morbidade do grupo estudado. A orientação para o uso de procedimentos padrão ou especial de controle de infecção hospitalar usualmente fica afixada na porta do quarto do doente.

Para melhor ilustrar as situações encontradas, segue-se o relato de alguns casos:

\section{Caso 1:}

Paciente do sexo masculino, 37 anos, ( completados durante a internação ), solteiro, escolaridade: $1^{\circ}$ grau, costureiro, morador da capital. Homossexual, parceiro (ex) falecido há 5 anos, com aids. HIV + recém diagnosticado ( dias ). Morava só, e após adoecer passou a morar com os pais aposentados e a irmã. Primeira internação.

Veio ao hospital com cefaléia, vômitos, diarréia, emagrecimento, síncope. Permaneceu com dor abdominal, diarréia, náuseas, vômitos. Diagnósticos finais: aids, neurotoxoplasmose, infeç̧ão por citomegalovirus, monilíase oral, insuficiência renal aguda, falência de múltiplos órgãos. Foi tratado com medicação específica para as doenças oportunistas e com sintomáticos. Recebeu atendimento psicológico. $O$ estado geral foi se deteriorando progressivamente durante o período, até a morte. 
Reclamou muito do incômodo causado pela sonda naso-gástrica. No $38^{\circ}$ dia de internação, reclama dos médicos e pessoal de enfermagem por não o ajudarem; no $41^{\circ}$ dia diz que quer comer macarrão no domingo; no $44^{\circ}$ dia diz que não agüenta mais ficar no hospital e quer ir para casa comer a comida feita por sua mãe; ao $46^{\circ}$ dia quer ir embora, diz que não agüenta mais ser puncionado. No $52^{\circ}$ dia: morre no hospital, em sedação terminal.

\section{Caso 2 :}

Paciente do sexo masculino, 34 anos, desquitado, bancário, procedente da Grande São Paulo. HIV + há 3 anos, após transfusão de sangue. 4 internações anteriores ( 2 tentativas de suicídio ).

O paciente chegou ao hospital com febre, dispnéia, queda do estado geral. Durante a evolução apresentou choque hipovolêmico e foi tratado na U.T.I. por 3 dias. Diagnósticos: aids, tuberculose pulmonar, endocardite bacteriana, insuficiência aórtica. Recebeu tratamento para tuberculose, anti-coagulantes, antibióticos, antidepressivos e medicação sintomática para dor e febre. Foi atendido por cardiologista, psiquiatra, psicólogo. Seu estado geral foi apresentando piora progressiva; ao final foi considerado com "prognóstico reservado". Morreu no $38^{\circ}$ dia de internação, após duas paradas cárdio-respiratórias, tendo sido submetido a reanimação, entubação e respiração mecânica por algumas horas, entre a primeira e a segunda parada.

\section{Caso $3 *$ :}

Paciente do sexo feminino, 32 anos, separada, escolaridade: $1^{\circ}$ grau, prendas domésticas, moradora da capital. HIV + desde há 5 anos, parceiro (ex) HIV + . Morando com os pais e o filho HIV + . Diversas internações anteriores. Paciente em seguimento no hospital-dia do I.I.E.R., em tratamento de infecção pelo CMV.

Diagnósticos: aids, tuberculose, pneumocistose, infecção por MAC, neurite, uveíte e cório-retinite por CMV.

Paciente foi internada por 12 dias, com dor abdominal a esclarecer, angústia e ansiedade. Teve alta e retornou 6 dias após, referindo agonia e insônia. 
Permaneceu inquieta. nervosa, referindo "dor de barriga de nervoso". O atendimento psicológico realizado no Pronto Socorro no segundo dia, deixou registrado: "paciente consciente, discretamente confusa; instabilidade emocional, ansiedade intensa; diz que vai embora de qualquer jeito no dia de hoje." Foi medicada pelo psiquiatra, devido a agitação e pânico. Morreu confusa, agitada, no dia seguinte. Foi submetida a manobras de ressuscitação, com cardioversão e respiração assistida. Estava sem acompanhantes.

* : paciente do grupo piloto ( teste do instrumento de coleta de dados ).

Os casos relatados são, ao mesmo tempo, relatos clínicos e histórias de pessoas em fase terminal, comuns no hospital. Embora a assistência prestada apresente-se técnica e eticamente correta para as condições encontradas - e não faz parte dos objetivos deste estudo analisá-la sob esse ângulo - as histórias relatadas nos prontuários médicos evidenciam, em todos os casos, a presença de sofrimento. Evidenciam também um atendimento de alta complexidade, feito por profissionais de diversas especialidades, com a realização de numerosos procedimentos, mesmo quando o prognóstico registrado não deixa dúvidas quanto à precariedade das condições clínicas do paciente e esgotamento de sua capacidade de resposta às intervenções curativas agressivas. Quase sempre o paciente morre sozinho. 


\section{$\mathrm{X}$ - Conclusões e recomendações}

"The concept of a good death / ... J also requires the
art of deliberately creating a medical environment
that allows a peaceful death. Somewhere between the
unacceptable extremes of failure to treat the dying
patient and intolerable use of aggressive life-
sustaining measures, the physician must seek a level
of care that optimizes comfort and dignity." 34

(Wanzer et al. 1989, p. 846)

\section{Conclusões:}

A assistência à saúde tem fundamental importância na diminuição do sofrimento humano, contribuindo inegavelmente para o bem estar das pessoas. A forma hegemônica com que ela tem sido exercida nas sociedades ocidentais modernas é a da assistência médica, em múltiplas possibilidades de organização. Essencialmente dirigidas à cura das doenças, as práticas de saúde desenvolvidas nas sociedades industrializadas muitas vezes negligenciam as ações preventivas e paliativas, reservando papel central aos hospitais na prestação da assistência. Os serviços hospitalares são concentradores de recursos e complexidade tecnológica, e difusores de novos conhecimentos e práticas. As recentes conquistas na área da saúde advindas do progresso técnico e científico têm se acompanhado de uma acentuada elevação dos custos da assistência, cada vez mais complexa, com conseqüente procura de práticas alternativas. Atendimento domiciliar, ampliação das indicações de tratamento em regime ambulatorial e hospital-dia são algumas dessas alternativas recentemente implementadas em paises desenvolvidos e também no Brasil. Outras justificativas para a introdução dessas novas práticas incluem a diminuição da incidência de infecções hospitalares e o maior conforto do tratamento. Importa poder contar com vários modelos de serviços, para se escolher, em cada situação, a alternativa mais adequada.

\footnotetext{
34 " $O$ conceito de uma boa morte (....) requer também a arte de criar, deliberadamente, um ambiente médico que permita morrer em paz. Em algum lugar, entre os inaceitáveis extremos da falha em tratar o paciente agonizante e o intolerável uso de medidas agressivas de sustentação da vida, o médico deve buscar um nivel de cuidados que otimize o conforto e a dignidade."
} 
A definição de prioridades na área da saúde - onde necessidades podem facilmente se confundir com desejos - e de padrões de qualidade é extremamente difícil, dada a variabilidade e individualidade dos resultados possíveis. É preciso considerar tanto as características epidemiológicas como os costumes e valores da população a ser atendida, na formulação das políticas de sáude. No caso do atendimento aos doentes em fase terminal, por tratar-se de um tema dificilmente tratado nas sociedades ocidentais contemporâneas, raramente se consegue verificar demanda popular por essa assistência, apesar da magnitude da clientela potencial e da precariedade do atendimento corrente nos hospitais gerais, em todo o mundo. $\mathrm{O}$ movimento hospice americano constituiu uma exceção importante, inserido em um movimento histórico-social mais amplo, de resgate de direitos do cidadão e é, por isso mesmo, apresentado destacadamente em um dos capítulos deste estudo. Esse relativamente novo modelo assistencial, bastante difundido hoje em países desenvolvidos, principalmente na Inglaterra onde nasceu e nos Estados Unidos da América, tem sido fonte de ensinamentos no atendimento a doentes morrendo, e deu origem a uma nova especialidade na área de saúde, a dos cuidados paliativos.

Morrer não é primordialmente um problema médico. É um evento natural, tanto quanto o nascimento, em que cabe aos serviços de saúde, orientar, prevenir complicações, assistir e tratar, sempre que possível, as dores e desconfortos. O sofrimento da morte envolve tanto sintomas fisicos como também necessidades emocionais, sociais e espirituais, responsáveis pela "dor total" descrita por Dame Cicely Saunders, fundadora do conceito Hospice de assistência à fase final da vida. É fundamental não se esquecer que ao lado da sintomatologia física e mental, tão valorizadas na formação médica e no ambiente hospitalar convencional, estão as preocupações sociais e espirituais do paciente, muitas vezes maiores e mais importantes ao não se pode contar com possibilidades terapêuticas de cura.

A experiência de internação hospitalar, em geral desagradável para a maioria dos doentes - em qualquer fase da doença - se justifica principalmente pelas expectativas de melhora da saúde e bem estar. Isto é, os pacientes a suportam em função da cura, ou do alívio de seus sintomas e desconfortos. Para os doentes que são levados ao hospital para viver sua fase final, os beneficios da internação podem 
ter um alto custo. em termos do alívio de seus males. A aderència às rotinas e restrições hospitalares usualmente se acompanha de desconforto e isolamento. A agonia e morte em ambiente hospitalar, com suas dores e solidão, é quase sempre temida ( Angerami-Camon 1997 ). Embora não se disponha de estudos semelhantes para a população brasileira, pesquisas realizadas em diversas nações mostram a preferência das pessoas, doentes e sadias, pela morte em casa, como já referido.

A qualidade da assistência ao paciente terminal, na perspectiva dos doentes, fundamenta-se na resposta às necessidades explicitadas por eles e seus familiares e/ou cuidadores, como verificado em algumas investigações: receber adequado alivio da dor e de outros sintomas, evitar o inadequado prolongamento do processo de morrer, manter senso de controle, aliviar o peso imposto a seus entes queridos, e fortalecimento dos laços afetivos ( Singer et al. 1999 ); ou ainda: bloqueio da dor, sem levar à inconsciência, conforto à angústia mental causada pelo medo de abandono e isolamento, apoio social e espiritual ( Friel 1982 ); conforto e alívio dos medos: da dor e de outros sintomas, do abandono, da não existência, da indignidade ( perda de controle de esfincteres, confusão mental, lesões desfigurantes ou mal cheirosas ), da perda de controle físico, social, financeiro, etc., medo de que os profissionais de saúde não saibam ou não possam ajudá-los ( Schofferman 1986 ).

A qualidade da assistência aos pacientes nessa fase inclui também a assistência a familiares e demais cuidadores do paciente, uma vez que o processo de morrer e a morte afetam diretamente o núcleo próximo ao paciente, e a fase após a morte é um período de dificil ajustamento para muitos (Bascon e Tolle 1995 ). A inexistência de acomodações para familiares nos hospitais, a pouca flexibilidade dos regulamentos, e a dificuldade que muitos profissionais - principalmente médicos têm de incluir os familiares dos doentes nos tratamentos e tomadas de decisão comprometem a qualidade da assistência ( Wanzer et al. 1989 ). Vários estudos têm mostrado a maior vulnerabilidade dos cuidadores a adoecer e se acidentar, durante o processo de cuidar e na fase de luto (Speer 1998, Emanuel e Emanuel 1998 ).

Por último, mas não menos importante, a qualidade da assistência, vista pelos próprios profissionais, inclui resposta satisfatória ao questionamento sobre " $a$ transição do gravemente doente, mas combatendo a morte, para a fase terminal, 
procurando paz, mudando os objetivos do tratamento: de cura ou sobrevida prolongada para preservação de conforto e dignidade." ( Finucane 1999 p. 1670 ). De fato, a racionalidade da terapêutica é variável, de acordo com cada fase da doença, com expectativas, metas e nivel de toxicidade aceitável diferenciados, nos modos curativo, paliativo e terminal ( Ashby e Stoffel 1991 ). É importante evitar as situações em que o paciente recebe tratamento, medicamentos e procedimentos, mas não recebe a assistència requerida (Williams 2000 ).

A necessidade de uma nova abordagem dos doentes sem possibilidades de cura vem despontando no Brasil desde há cerca de duas décadas, principalmente entre profissionais de saúde que trabalham na área de Oncologia, manifesta nas publicações especializadas, na realização de palestras, cursos, congressos, e na criação de associações profissionais relacionadas a essa temática

Novas práticas assistenciais relacionadas ao atendimento ao doente com aids em fase terminal vêm se configurando, como se verificou na implementação da assistência domiciliar terapêutica ( ADT), promovida pela Coordenação Nacional do Programa de DST/Aids do Ministério da Saúde.. Esse órgão governamental, responsável pelas diretrizes programáticas referentes ao controle da endemia e assistência aos portadores de aids em todo o território nacional, declarou recentemente sua intenção de promover a conduta paliativa entre as práticas assistenciais por ele recomendadas, objetivando proporcionar uma melhor qualidade de vida aos pacientes com aids em tratamento, em todas as fases de sua doença, incluindo a fase terminal. E está iniciando um processo de capacitação em cuidados paliativos, dos profissionais que atuam nos serviços prestadores de assistência.

O caso do Instituto de Infectologia Emílio Ribas da Secretaria de Estado da Saúde de São Paulo, centro de referência nacional para o tratamento e ensino de aids e doenças infecciosas em geral, ilustra a constatação e acolhimento da necessidade de se prestar uma assistência melhor qualificada aos doentes adultos com aids em fase terminal, internado em suas enfermarias, por parte dos profissionais nela envolvidos. Identifica também a emergência de práticas alternativas à assistência tradicional, na atuação - em caráter voluntário - de uma equipe multiprofissional de prestação de cuidados paliativos aos pacientes internados. De grande importância na 
história das epidemias no Brasil, este hospital é local privilegiado para a percepção de novas necessidades e estabelecimento de práticas inovadoras, no que diz respeito às moléstias infecciosas. A epidemia de aids, que trouxe para suas enfermarias a agonia e morte de adultos jovens, suscitou reflexões e mudanças nas práticas de seus profissionais, como o atendimento em regime de hospital-dia há mais de 10 anos, o atendimento comunitário nas Casas de Apoio, há cinco anos, e agora a introdução do atendimento em cuidados paliativos.

O papel central desse hospital na prestação de serviços a pacientes com aids na região da Grande São Paulo também ajudou a consolidá-lo como local onde se assiste ao morrer dos pacientes sem possibilidades de cura. As dificuldades próprias do tempo moderno para a ocorrência da morte em domicílio, logísticas e culturais, além da incerteza prognóstica, reforçam a procura da assistência hospitalar para tratamento e morte dos pacientes em fase final. Os dados colhidos junto ao Programa de Aprimoramento de Informações de Mortalidade do Município de São Paulo, confirmam esse fato para nossa cidade. A ocorrência média mensal de cerca de vinte e seis óbitos de adultos devidos à aids, verificada no I.I.E.R. nos últimos dois anos, demonstra a magnitude dessa população doente em fase terminal nas suas enfermarias, sem esquecer o expressivo e lamentável registro de mais de sete mil mortes por aids, acumuladas no período de Janeiros de 1984 a Junho de 2000.

A emergência de novas necessidades no campo da assistência aos pacientes adultos portadores de aids, tais como percebidas pelos profissionais que as realizam quotidianamente, ocorre ao tempo em que a aids vem deixando de ser uma doença de evolução curta para tornar-se uma doença crônica controlável, mas ainda letal. É nessa fase da história da pandemia de aids que as preocupações dos profissionais que atendem os pacientes se voltam para a qualidade de vida dos doentes. Agora pacientes e profissionais contemplam o tratamento a longo prazo. Esse novo olhar para o atendimento realizado, onde a qualidade de vida do paciente importa mesmo que não se possa proporcionar-lhe a cura é um dos pilares da prática dos cuidados paliativos.

Características particulares do doente com aids em fase terminal colocam algumas dificuldades adicionais à vivência do processo de adoecimento e morte: 
trata-se geralmente de paciente jovem, sofrendo isolamento social devido ao estigma que ainda hoje cerca os portadores dessa doença ou às condições de vida freqüentemente à ela associadas ( Ferris et al. 1995, Wood et al. 1997 ). Além disso, esses pacientes costumam apresentar a concomitància de múltiplas patologias e fazer uso de numerosos medicamentos, com seus efeitos colaterais e mudança de hábitos. Para os profissionais de saúde e principalmente para os médicos, a grande dificuldade na assistència a esses doentes é a própria definição de terminalidade, decorrente da incerteza prognóstica. Muitas vezes definida a posteriori e arbitrariamente na literatura médica - duração do último episódio mórbido que levou à morte, duração da última internação hospitalar, últimos três meses de vida, últimos seis meses de vida, etc. - a definição de fase terminal é um conceito operacional importante para a indicação das condutas apropriadas ( Stansell e Follansbee 1995, Fantoni et al. 1996, Welch et al 1998 ). O grande desenvolvimento verificado nos últimos anos no arsenal terapêutico de combate ao vírus HIV e também às doenças oportunistas que podem levar o paciente à morte, dificulta um pouco mais a realização de prognósticos acurados. No entanto, existem critérios clínicos bastante utilizados em países desenvolvidos, e particularmente nos Estados Unidos da América, para guiar a conduta médica, através de exames clínico e laboratoriais ( baseados em declínio físico, morbidade associada 'a aids, dosagem de células CD4 e de carga viral ) rotineiramente realizados no seguimento dos pacientes portadores de aids também aqui no Brasil ( Stansell and Follansbee 1995, MS 1999 c, Gallant 2000)

Este estudo identificou uma grande carência de parâmetros, entre os médicos do I.I.E.R., para a interrupção do tratamento curativo e implementação de medidas paliativas aos pacientes com aids em fase final, parâmetros esses não tanto técnicos, mas principalmente éticos e legais, que dêem respaldo à conduta tomada. $\mathrm{A}$ realização de procedimentos agressivos e/ou invasivos de prolongamento da vida em condições precárias, como o caso de vigorosas tentativas de ressuscitação, a grande manipulação para investigação diagnóstica em doentes com prognóstico "reservado" ou o tratamento em UTI para pacientes com falência de múltiplos órgãos, atestam o investimento médico nas atividades de evitamento da morte, mesmo em situações bastante improváveis. 
O estudo dos prontuários médicos dos doentes falecidos no I.I.E.R expõem um inequívoco sofrimento: os pedidos explícitos e reiterados de retorno ao lar, o isolamento dos familiares, a ansiedade e a angústia, a manipulação invasiva. Sofrimento que parece ser excessivo - quando comparado com o desejável - e também inevitável, quando tomadas em consideração as circunstâncias em que se dá a assistência. No caso, essas circunstâncias dizem respeito a um hospital de tratamento de doenças infecciosas: local onde o controle das infecções hospitalares é crucial para o restabelecimento dos pacientes portadores de doenças curáveis, onde o tratamento agressivo de infecções agudas pode ser o diferencial entre a vida e a morte de muitos pacientes, e onde a execução rígida de regulamentos e procedimentos rotineiros tem sido condição básica para o exercício das funções.

Alguns trabalhadores das várias categorias profissionais desse hospital, também voluntários das capelanias, têm procurado capacitar-se para exercer o atendimento aos pacientes internados em fase terminal, através de um processo individual de busca de aprimoramento e especialização nesse tema, e também através da formação de uma equipe multiprofissional para a realização de trabalho voluntário em cuidados paliativos, como se verificou neste estudo. Esse fato indica uma inegável lacuna na formação, bem como a percepção dessa carência por parte dos profissionais, além do esforço individual para responder a essa situação.

Importante notar que a preocupação com a melhoria da qualidade dessa assistência já vinha existindo entre profissionais do I.I.E.R., de modo episódico ou pontual, desde há alguns anos. Mas sem gerar uma demanda sistematizada aos níveis hierarquicamente superiores, técnico ou administrativo. Conforme relatado pelos dirigentes entrevistados, as diretorias recebiam eventualmente alguma demanda específica, como pedido de compra de algum insumo, mas apenas isso. Tanto os dirigentes do Instituto de Infectologia Emilio Ribas como o diretor da Coordenação dos Institutos de Pesquisa mostraram-se abertos à formulação e implantação de novas práticas, tal como as que vêem ocorrendo atualmente no I.I.E.R., visando a melhoria da assistência aos doentes internados em fase final, embora essa problemática não fizesse parte de sua propostas programáticas, e só tenha surgido, como conjectura, por ocasião da entrevista para este estudo. Mudanças estruturais, 
no entanto, como designação de leitos especificos para o atendimento a esses pacientes, encontram maiores resistências. Provimento de recursos humanos exclusivamente dedicados a essa atividade, de área física ou de recursos financeiros foram tidos como praticamente inviáveis, no momento, devido à insuficiência geral de recursos da instituição para a sua manutenção. A atuação da Equipe de Cuidados Paliativos foi apoiada pelo diretor técnico do I.I.E.R., tanto em suas atividades assistenciais, integradas àquelas desenvolvidas pelos responsáveis pelo paciente internado, como em suas atividades de auto capacitação e de ensino, desde que realizadas em caráter voluntário por seus membros.

A pesquisa junto aos profissionais que atuam no I.I.E.R. demonstra a necessidade de melhoria da assistência especializada aos doentes morrendo no hospital, em sua própria avaliação. Mais ainda: identifica a emergência de novas práticas, quer timidamente em experiências profissionais individuais, que se realizam devido a esforços isolados, quer já de modo oficializado, como a criação e atuação voluntárias de uma equipe multiprofíssional para prestar assistência em cuidados paliativos a pacientes internados e posteriormente em nivel ambulatorial.

Suas sugestões - numerosas e consistentes - indicam caminhos escolhidos para melhorar a qualidade da assistência aos doentes terminais por eles atendidos e grande parte dessas sugestões são potencialmente factiveis, numa instituição como o I.I.E.R.. Exemplos de propostas de mais fácil viabilização são a realização de palestras e treinamentos dirigidos a todas as categorias profissionais, visando um novo enfoque institucional sobre a assistência a esses pacientes, e discussão aprofundada de temas complexos como a conduta médica de interrupção de tratamento curativo, com o objetivo de estabelecer diretrizes ética e legalmente respaldadas. Outras sugestões colhidas nos depoimentos dos profissionais do I.I.E.R.. que prestam assistência direta aos pacientes se referem a mudanças em regras e rotinas de funcionamento da instituição, ou ao menos sua flexibilização. Sua factibilidade é variável, dependendo de vontade política, situações conjunturais da instituição, disponibilidade de recursos específicos e habilidade nas negociações, por parte dos envolvidos. São elas: implementação da atuação multiprofissional integrada, com melhora da comunicação entre os membros das equipes; capacitação 
técnica, com reciclagens e supervisão; suporte emocional para lidar com as situações dificeis; adequação material ( espaço físico, equipamentos, insumos ), no que se refere às condições gerais de trabalho, e adequação de horário de visitas, facilitação das licenças médicas e "humanização" do atendimento, no que se refere à assistência recebida pelo doente.

Resumindo:

* Este estudo identificou a configuração de necessidades não atendidas através das práticas assistenciais convencionais, dos pacientes adultos com aids atendidos no Instituto de Infectologia Emílio Ribas, percebidas e acolhidas inicialmente pelos profissionais envolvidos diretamente na execução da assistência, e a seguir pelos profissionais responsáveis pela formulação e gestão das políticas e diretrizes programáticas a ela relacionadas;

Tanto a magnitude como o perfil demográfico e epidemiológico dos pacientes alvo puderam ser traçados, auxiliando o reconhecimento da clientela à qual se destinam as ações. Os resultados das investigações realizadas evidenciaram a ocorrência de quase um óbito por dia ( 25,9 / mês ) de pessoa adulta com aids, nos últimos dois anos e meio, nesse hospital. Entre outras características, o estudo mostrou grande freqüência de mortes de adultos jovens de escolaridade baixa, e proporção considerável ( $61,0 \%$ ) dos pacientes vivendo seu primeiro episódio de internação hospitalar no I.I.E.R. Cerca de $1 / 3$ dos pacientes falecidos relatavam história recente ( até 6 meses ) da doença.

* Na avaliação dos profissionais diretamente envolvidos na prestação da assistência aos pacientes em geral, a qualidade do atendimento dispensado aos pacientes com aids em fase terminal tratados nessa instituição é ligeiramente inferior à do atendimento dispensado aos demais. Média das notas atribuídas: 3,9 para o atendimento geral, e 3,4 para fase terminal, com valor mínimo $=1 \mathrm{e}$ máximo $=5$. Cerca de $40 \%$ dos profissionais entrevistados, incluindo todas as categorias profissionais, relataram pouca ou nenhuma facilidade para realizar o atendimento a esses pacientes, embora mais de $75 \%$ deles relatem grande freqüência em executá-lo. 
* O estudo identificou a emergência de novas práticas, tanto como iniciativas pontuais e isoladas de profissionais motivados e com autonomia de trabalho, como em iniciativas grupais, mais sistematizadas, como a organização coletiva que deu origem à criação da Equipe Multidisciplinar Voluntária de Cuidados Paliativos do I.I.E.R., em Julho de 1999. Também surpreendeu iniciativas da Coordenação Nacional do Programa de DST/Aids do Ministério da Saúde para a promoção dos cuidados paliativos na assistência aos doentes com aids.

Apesar das limitações deste estudo, metodológicas ( estudo de caso, insuficiência de dados registrados em prontuários médicos ) e contingenciais, esta pesquisa traz subsídios para a implementação da assistência a doentes com aids em fase terminal nos hospitais brasileiros, ao menos no que tange à suscitação de questionamentos.

\section{Recomendações:}

Gerais:

- Que as instituições de ensino na área da saúde, e principalmente aquelas de ensino médico, se envolvam com a questão da assistência ao paciente em fase terminal; que não se formem profissionais de saúde que olham aqueles que estão morrendo como se eles não existissem, ou como se não houvesse nada a fazer por eles.

- Que as entidades profissionais da área da saúde - conselhos, associações, etc. invistam na discussão dessa problemática, realizando periodicamente, palestras e fóruns de discussão sobre as questões éticas e legais relacionadas à assistência ao doente em fase terminal, envolvendo também grupos da sociedade interessados na qualidade da assistência à saúde e nos direitos do cidadão. 
- Que instituições de ensino e pesquisa se interessem pela realização de estudos junto a pacientes e familiares com o objetivo de verificar suas necessidades e a satisfação com a assistência recebida, em se tratando da assistência à fase terminal e ao luto dos familiares após a morte do doente. Embora não se possa detectar uma demanda dos usuários para a implantação de modelos assistenciais desconhecidos para eles, é possível ao menos detectar quais são suas maiores dificuldades com a assistência convencional e traçar propostas para solucionálas.

- Que instituições de prestação de serviços de saúde, públicas e privadas, estudem a possibilidade de incorporar o conceito hospice de assistência, em qualquer uma de suas modalidades, para os doentes em fase terminal.

- Que se busquem parâmetros nacionais para uma definição operacional de terminalidade e para realização mais acurada de prognósticos em aids, auxiliando a tomada de decisões dos profissionais quanto aos tratamentos propostos, e dos pacientes e seus familiares, quanto à resolução de questões pessoais.

- Que os tratamentos propostos para os pacientes, internados ou não e em qualquer fase de suas doenças, possam ser estabelecidos conjuntamente com os vários membros das equipes multiprofissionais, e incluindo também o paciente e/ou seus familiares ou responsáveis. Que se encontre respaldo legal para as decisões médicas fundamentadas tanto em seu conhecimento técnico e conduta ética, como no respeito às necessidades expressas pelo paciente.

Para o Instituto de Infectologia Emílio Ribas:

- Que se envolva o conjunto dos profissionais da instituição na busca de melhora constante da qualidade da assistência prestada, com enfoque no tratamento da pessoa doente e não na doença. 
- Que se desenvolvam discussões aprofundadas, com a presença de especialistas reconhecidos na área, sobre a assistência a pacientes em fase terminal, com o intuito de sensibilização dos menos afeitos a ela e aprimoramento profissional de todos.

- Que temas relacionados à terminalidade e à assistência integral a doentes e familiares sejam incluídos na programação de internos, residentes e estagiários.

- Que seja incentivada e possibilitada a capacitação - técnica e emocional - dos profissionais envolvidos na assistência a pacientes em fase terminal.

- Que a definição de metas para o tratamento, em cada caso, possam se estabelecidas em equipe e com o paciente e/ou seus familiares ou responsáveis.

- Que se implante o serviço de voluntários, devidamente selecionados e treinados, para fazer companhia a pacientes solitários que assim o desejarem e realizar atividades de apoio a familiares e cuidadores, quando necessário.

- Que se busquem condições para a implantação de atendimento domiciliar e de enfermaria apropriada para a assistência ao doente em fase terminal, propiciando a prestação de cuidados continuados e adequados à essa condição.

- Que se implemente o atendimento a familiares nas dependências do I.I.E.R., e se destine um espaço privado para a comunicação de más notícias e descanso dos acompanhantes de pacientes. 
Um ideal a ser atingido:

Desenvolver uma consciência geral da importância do cuidar, principalmente quando curar não é mais possivel; da prevalência da dor total, com seus componentes fisico, psíquico e espiritual; do respeito às preocupações do doente; da aceitação da morte como um evento natural como o nascimento, o qual os profissionais de saúde devem assistir orientando, prevenindo complicações, aliviando sofrimento, auxiliando a torná-lo um evento menos doloroso, digno, para todos os que dele participam.

Um dia poder contar no I.I.E.R. com uma enfermaria acolhedora, com paredes azuis, iluminação e música ambiente suave, portas e janelas abertas para o jardim, flores na mesa e quadros nas paredes, onde os profissionais, voluntários e entes queridos do paciente possam transitar livremente, prestando-lhe assistência integrada e contínua, aliviando o melhor possível o seu sofrimento fisico, mental, social e espiritual, para que ele possa viver com conforto e dignidade a vida que lhe resta. 


\section{Referências bibliográficas}

Aalen OO, Farewell VT, De Angelis D, Day NE, Gill ON. New therapy explains the fall in AIDS incidence with a substantial rise in number of persons on treatment expected. AIDS 1999; 13:103-8.

Abel EK. The Hospice Movement: institutionalizing innovation. Int $J$ Health Services 1986; $16(1): 71-8$.

Abiven M. Les soins palliatifs, une discipline medicale pour la fin de la vie. Bull Acad Natl Med 1999; $183: 881-7$.

Acurcio FA, Guimarães MDC. Acessibilidade de indivíduos infectados pelo HIV aos serviços de saúde: uma revisão de literatura. Cad Saúde Pública 1996; $12: 233$ -42 .

Adler MW. Care for patients with HIV infection and AIDS. BMJ 1987; 295 (6589): $27-30$.

Aires EM, Cota IN, Chaves CEV, Bammann RH, Longo JC. Aspectos clínicos e implicações terapêuticas da dor em pacientes HIV-positivos internados: resultados preliminares. BJID 1999; 3 ( Suppl 2 ): S $66.11^{\circ}$ Brazilian Infectious Diseases Congress. São Paulo, 1 - 4 Aug 1999. ( Poster 157 ).

Alvarez A, Mohar A, Kraus A. En torno a la muerte: una revision y una propuesta. Rev Invest Clin 1997, 49 ( 2 ): 151 - 61 .

[ AMA ] Council on Ethical and Judicial Affairs, Americam Medical Association. Guidelines for the Appropriate Use of Do-Not-Resuscitate Orders. JAMA 1991; $265: 1868-71$.

[ AMA ] Council on Scientific Affairs of the Americam Medical Association. Good Care of the Dying Patient. JAMA 1996; $275: 474$ - 8.

Amenta MOR Hospice in the United States: multiple models and varied programs. Nursing Clinics of North America 1985, 20 ( 2 ): 269 - 79.

Angerami-Camon VA. ( org ) Psicologia hospitalar: teoria e prática. São Paulo: Pioneira; 1997. Pacientes terminais: um breve esboço. p. $77-114$.

[ Anonymus ]. Projeto de Atendimento Comunitário: Uma lição de solidariedade. Infecto Atual 2000; Ano I ( 1 ): 12 . 
Antunes JLF. Hospital: Instituição e História Social. São Paulo: Letras \& Letras; 1991.

Ariès P. O Homem diante da morte. - vol. II. Rio de Janeiro: Francisco Alves, 1990.

Arras JD and Dubler NN. Ethical and social implications of high-tech home care. In: Arras JD (editor) Bringing the Hospital Home: ethical and social implications of high-tech home care. Baltimore: The Johns Hopkins University Press, 1995.

Ashby M, Stoffell B. Therapeutic ratio and defined phases: proposal of ethical framework for palliative care. BMJ 1991; 302: 1322 - 4 .

Atkins BL, Kohn P. An infectious disease care unit - the first year. J Infect 1992; 25 ( 2 ): $191-6$.

Atkinson SJ. Anthropology in research on the quality of health services. Cad Saúde Públ 1993; $9: 283-99$.

Azevedo AC. O futuro dos hospitais e a gestão da qualidade. Rev Paul Hosp 1992; 40 ( 5-12): $53-9$.

Baldessin A. O Idoso: Viver e Morrer com Dignidade. In: Papaléo Netto M. ( org ). Gerontologia. São Paulo: Atheneu; 1996. p. 491 - 8.

Barrenechea JJ. La selección de prioridades como integrante del proceso de decisión. In: Sonis A. Medicina sanitária y administración de salud. Buenos Aires: 1971 p. $206-14$.

Bascon PB, Tolle SW. Care of the family when the patient is dying. West $\mathbf{J}$ Med $1995 ; 163: 292-6$.

Bashshur, R. Sobre la evaluatión de las necesidades de salud. Salud Publica Mex 1987; $29: 288-92$.

Becker E. A negação da morte. Rio de Janeiro: Record; 1995.

Beresford L, Connor SR. History of the National Hospice Organization. Hosp J $1999 ; 14(3-4): 15-31$.

Bilchik GS. Dollars \& Death. Hospitals \& Health Networks 1996; 70 (24): 18 -22.

Billings JA, Block S. Palliative care in undergraduate medical education. JAMA 1997; 278 ( 9 ): $733-8$.

Boemer MR, Veiga EV, Mendes MM, Valle ERM. O tema da morte: uma proposta de educação. Rev Gaúcha Enf 1991; 12 ( 1 ) 26 - 32. 
Boquet $P$. Une autre ideé du soin. In: Launois $R$. Des remèdes pour la santé. Paris: Masson; 1989.

Breitbart W, Kaim M and Rosenfeld B. Clinicians' perceptions of barriers to pain management in AIDS. J Pain Symptom Manage 1999; 18: 203 - 12.

Brody H. Assisted death - A compassionate response to a medical failure. $\mathbf{N}$ Engl $\mathbf{J}$ Med 1992; $327: 1384-8$.

Bromberg MHPF. Cuidados paliativos para o paciente com câncer: uma proposta integrativa para equipe, pacientes e familias. In: Carvalho MMMJ, organizadora. Psico-Oncologia no Brasil: resgatando o viver. São Paulo: Summus, 1998. p. 186 $-231$.

Bulkin W, Lukashok H. Rx for dying: the case for hospice. N Engl J Med 1988; 318: $376-8$.

Byock I. Beyond symptom management. Eur J Pall Care 1996; 3 ( 3 ): 125 - 30.

Byock I. Completing the Continuum of Cancer Care: Integrating Life-Prolongation and Palliation. CA Cancer J Clin 2000; $50: 123$ - 32.

Callahan D. What Kind of Life. New York: Simon \& Schuster; 1990.

Callahan D. Frustrated Mastery - The Cultural Context of Death in America. West J Med 1995; 163 ( 3 ): 226 - 30.

Callahan D. Death and the Research Imperative. N Engl J Med 2000; 342: 654 - 6.

Camargo AMF. A AIDS e a sociedade contemporânea - estudos e histórias de vida. São Paulo: Letras \& Letras; 1994.

Canguilhem G. O normal e o patológico. Rio de Janeiro: Forense-Universitária; 1982.

Carapinheiro G. Saberes e poderes no hospital. Porto: Afrontamento; 1993, $2^{\circ}$ ed.

Carvalho LF. O hospital moderno. Rev Paul Hosp 1988; 36 ( $7 / 9$ ): 149 - 53.

Carvalho MMMJ e Kovács MJ. Psico-Oncologia no Brasil: desenvolvimento de um campo de trabalho e pesquisa. In: Carvalho MMMJ, organizadora. Psico-Oncologia no Brasil: resgatando o viver. São Paulo: Summus, 1998. p. 142 - 158.

Casseb J, Pereira Jr. LC, Silva GL, Medeiros LA. Decreasing mortallity and morbidity in adults AIDS patients from 1995 to 1997 in São Paulo, Brazil. AIDS Patient Care STDs $1999 ; 13: 213-4$. 
Cassel EJ. The nature of suffering and the goals of Medicine. $\quad \mathbf{N}$ Engl $\mathbf{J}$ Med $1982 ; 306: 639-45$.

Cassorla RMS, coordenador. Da morte: estudos brasileiros. Campinas, SP: Papirus, 1991.

Cavalcante NJF. Infecção em Pacientes Imunologicamente Comprometidos. In: Fernandes AT ( editor) Infecção Hospitalar e suas interfaces na área da saúde. São Paulo: Atheneu, 2000.

Cecílio LCO. O desafio de qualificar o atendimento prestado pelos hospitais públicos. In: Merhy EE, Onocko $\mathrm{R}$, organizadores Agir em saúde: um desafio para o público. São Paulo: Hucitec / Buenos Aires: Lugar; 1997. p. 293 - 320.

Chaimowicz F. A saúde do idoso brasileiro às vésperas do século XXI: problemas, projeções e alternativas. Rev saúde públ 1997; $31: 184$ - 200.

Charles C, Lomas J, Giacomini M. Medical necessity in Canadian Health policy: four meanings and ... a funeral ? Milbank Q 1997; 75: 365 - 94.

Chin AE, Hedberg K, Higginson GK, Fleming DW. Legalized physician-assisted suicide in Oregon - the first year's experience. N Engl J Med 1999; 340: 577 - 83.

Christakis NA and Escarce JJ. Survival of Medicare patients after enrollment in hospice programs. N Engl J Med 1996; 335: 172 - 8.

Christakis NA, Lamont EB. Extent and determinants of error in doctors' prognoses in termminally ill patients: prospective cohort study. BMJ 2000; $320: 469-73$.

Clark D. Someone to watch over me. Nursing Times 1997; 93 ( 34 ): 50 - 2.

Clarke A. What is a chronic disease ? The efects of a re-definition in HIV and AIDS. Soc Sci Med 1994; 39 ( 4 ): 591 - 7.

Cleary PD, McNeil BJ. Patient Satisfaction as an Indicator of Quality Care. Inquiry $1988 ; 25: 25-36$.

Cohn A, Nunes E, Jacobi P, Karsch US. A saúde como direito e como serviço. São Paulo: Cortez; 1991.

Cohn A, Elias PE. Saúde no Brasil: políticas e organizações de serviços. São Paulo: Cortez; 1996.

Condra JH. Resisting resistance: maximizing the durability of antiretroviral therapy. (editorial) Ann Intern Med 1998, $128: 951-4$. 
Consorte J. A morte na prática médica. In: Martins JS ( org ) A morte e os mortos na sociedade brasileira. São Paulo: Hucitec, 1983. p. 38 -57.

Copp G. A review of current theories of death and dying. J Adv Nurs 1998, 28: $382-90$.

Cordeiro H. Medical costs of HIV and AIDS in Brazil. In: Fleming AF et al. The global impact of AIDS. New York: Alan R Liss; 1988. p. $119-122$.

Corr CA. Death in modern society. In: Doyle D, Hanks GW \& MacDonald N, editores. Oxford textbook of palliative medicine. Oxford: Oxford University Press; 1995. p. $28-36$.

Cowley LT, Young E, Raffin TA. Care of the dying: an ethical and historical perspective. Crit Care Med 1992, 20: $1473-82$.

Cruise PL. AIDS and long-term care: an examination of Florida's Medicaid Incentive Reimbursement Program. AIDS Patient Care 1994; 8:121 - 6 .

Dalmaso ASW. Estruturação e transformação da prática médica. São Paulo; 1998. [ Tese de doutorado - Faculdade de Medicina da USP ].

Danis M, Southerland LI, Garret JM, Smith JL, Hielema F et al.. A prospective study of advance directives for life-sustaining care. N Engl J Med 1991; 324: 882 - 8.

Dawson NJ. Need satisfaction in terminal care settings. Soc Sci Med 1991; 32: 83 7.

Detels R, Muñoz A, McFarlane G, Kingsley LA, Margolick JB, Giorgi J et al. Effectiveness of potent antiretroviral therapy on time to AIDS and death in men with known HIV infection duration. JAMA 1998; 280: 1497 - 503.

Dever GEA. A Epidemiologia na administração dos serviços de saúde. São Paulo: Pioneira; 1988.

Donabedian A. The quality of care: how can it be assessed ? JAMA 1988; 260: 1743 - 8 .

Douglas C. For all the saints. BMJ 1992; 304: 579.

Drummond M, Davies L. Treating aids: the economic issues. Health Policy 1988; 10: 1 - 19 .

Emanuel EJ. Cost Savings at the End of Life. JAMA 1996; 275: 1907 - 14.

Emanuel EJ, Emanuel LL. The promise of a good death. Lancet 1998; 351 ( suppl II ): $21-9$. 
Esserman L, Belkora J, Lenert L. Pottencially ineffective care. A new outcome to assess the limits of critical care. JAMA 1995; 274: 1544-51.

Evans RG, Stoddart GL. Producing health, consuming health care. Soc Sci Med $1990 ; 31: 1347-63$.

Evens RG. Making difficult health policy decisions: most choices are not simply life or death. Am J Roentgenol 1995; 165: 1329 - 30.

Fantoni M, Ricci F, del Borgo C, Bevilacqua N, Izzi I, Damiano F, Marasca G. Symptom profile in terminally ill patients. AIDS Patient Care STDs 1996; $10: 171$ -3 .

Feinberg AW. The Care of Dying Patients. Ann Intern Med 1997, $126: 164$ - 5.

Ferguson BM, Keown PA. An introduction to utility measurement in health care. Infect Control Hosp Epidemiol $1995 ; 16: 240-7$.

Ferris FD ( editor ). A comprehensive guide for the care of persons with HIV disease. Toronto: Mount Sinai Hospital / Casey House Hospice; 1995. Module 4: Palliative Care.

Figueiredo MTA. O desafio dos cuidados paliativos no Brasil. Âmbito hospitalar $1997 ; 12: 3-8$.

Figueiredo MTA. Educação em cuidados paliativos. Dor em foco 1999; 2 ( 3 ): 6 -7.

Finucane TE. How Gravely IIl Becomes Dying: a Key to End-of-life Care. JAMA 1999; 282: $1670-2$.

Fordham S, Dowrick C, May C. Palliative medicine: is it really specialist territory ? J R Soc Med 1998; $91: 568$ - 72.

Fortes PAC. Ética e saúde: questões éticas, deontológicas e legais, tomada de decisões, autonomia e direitos do paciente, estudo de casos. São Paulo: EPU; 1998.

Friel PB. Death and Dying. Ann Intern Med 1982, $97: 767-771$.

Gallant JE. Strategies for long-term success in the treatment of HIV infection. JAMA 2000; 283: 1329 - 34.

Gallo R. Caça ao vírus. São Paulo: Siciliano, 1994.

Garrett L. The coming plague. New York: Farrar, Straus and Giroux, 1994. 
Geiger HJ. The causes of humanization in health care and prospects for humanization. In: Howard $\mathrm{J} \&$ Strauss $\mathrm{A}$, editors. Humanizing Health Care. New York: John Wiley \& Sons; 1975. p. 11 - 36.

Ghezzi MIL. Convivendo com o ser morrendo. Porto Alegre: Sagra, 1991.

Gilbert J. Palliative medicine: a new specialty changes an old debate. Br Med Bull 1996; 52 ( 2 ): 296 - 307.

Gillick M. The High Costs of Dying. Arch Intern Med 1994; 154: 2134 - 7.

Goldstone IL. Trends in hospital utilization in AIDS care: 1987 - 1991: implications for palliative care. J Palliat Care 1992; 8 ( 4 ): 22 - 9.

Goldstone I, Kuhl D, Hohnson A, Le R, Mcleod A. Patterns of care in advanced HIV disease in a tertiary treatment centre. AIDS Care 1995; 7 supp. $1:$ S 47 - 56.

Gomes LC, Fraga MNO. Doenças, hospitalização e ansiedade: uma abordagem em saúde mental. R Bras Enferm 1997; $50: 425$ - 40.

Gomes MRO. Mortalidade por aids no Brasil - atualização até 1997. In: Ministério da Saúde. AIDS - Bol Epidemiol - 1998/1999; 12 ( 1 ): 3 - 9.

Grabois V e Sandoval P. Caminhos para uma nova política política hospitalar. In: Castelar RM, Mordelet P, Grabois V ( dir. ) Gestão hospitalar: um desafio para o hospital brasileiro. Rennes: ENSP; 1995. p. 69 - 79.

Greenberg M. Impediments to basing government health policies on science in the United States. Soc Sci Med 1992; $35: 531$ - 40.

Greer DS. Hospice: lessons for geriatricians. JAGS 1983; 31 ( 2 ): 67 -70.

Guattari F. Revolução Molecular: pulsações políticas do desejo. São Paulo: Brasiliense; 1985. $2^{\circ}$ ed.

Guerra MAT, Miura SRR, Barollo AT, Figueira Jr. JPA, Oshiro JH. O trabalho cotidiano com a AIDS: as representações dos profissionais de saúde em uma unidade hospitalar. São Paulo; 1992. [ Relatório de pesquisa - Instituto de Saúde / Instituto de Infectologia Emilio Ribas, Secretaria de Estado da Saúde de São Paulo ].

Guerra MAT. Política de controle da AIDS da Secretaria de Estado da Saúde de Såo Paulo, no período 1983 - 1992: a história contada por seus agentes. São Paulo; 1993. [ Dissertação de mestrado - Faculdade de Medicina da USP ].

Guerra MAT, Veras MASM, Ribeiro AF. AIDS: Epidemiologia. In: Veronesi R, Focaccia R ( ed. ). Tratado de Infectologia. São Paulo: Atheneu; 1996. p. 88-98. 
Gulick R. Antiretroviral therapy: where are we going ? AIDS Patient Care STDs $1998 ; 12: 515-8$.

Guthrie B, Nelson M, Gazzard B. Are people with HIV in London able to die where they plan? AIDS Care 1996; 8 (6): $709-13$.

Ham C. Learning from the tigers: stakeholder health care. Lancet 1996; 347 (9006): $951-3$.

Hammermeister KE, Shroyer AL, Sethi GK, Grover FL. Why it is important to demonstrate linkages between outcomes of care and processes and structures of care. Med Care 1995; 33 ( 10 Suppl. ): S 5 - 16.

Hansluwka HE. Measuring the health status of a population: current state of the art. Popul Bul U N 1987; ( $23 / 24)$ : $56-75$.

Hart JT, Dieppe P. Caring effects. Lancet 1996; 347 ( 9015 ): $1606-8$.

Haupt BJ. Characteristics of hospice care users: Data from the 1996 National Home and Hospice Care Survey. Advance data from vital and health statistics; $\mathrm{n}^{\circ} 299$. Hyattsville, Maryland: National Center for Health Statistics, 1998.

Helft PR, Siegler M, Lantos J. The Rise and Fall of the Futility Movement. N Engl J Med 2000; 343: 293 - 5.

Hernando A; Pulido F; Pena JM; Alberdi JC; Gonzalez-Garcia J; Rubio R et al. Influencia del hospital de dia en los requerimientos de ingreso hospitalario de los pacientes con SIDA. Med Clin (Barc) $2000 ; 114$ (18): 690 - 3.

Higginson I. Palliative care: a review of past changes and future trends. J Publ Hith Med 1993; $15(1): 3-8$.

Higginson IJ. Who needs palliative care ? J Royal Soc Med 1998; 91: 563 - 4 .

Hockley J. Specialist Palliative Care within the Acute Hospital Setting. Acta Oncologica 1999; 38 ( 4 ): 491 - 4 .

Hogg RS, O'Shaughnessy MV, Gataric N, Yip B, Craib K, Schechter MT et al. Decline in deaths from AIDS due to new antiretrovirals. Lancet 1997; 349: 1294.

Holman GH \& Smith DC. Board Certification in Palliative Care for U.S. Physicians. J Pain Symptom Manage. 1999; 17 ( 5 ): 309 - 10.

Hopkins A, Solomon JS. Can contracts drive clinical care ? BMJ 1996; 313 (7055): 477 - 8. 
Hunt R, Bonett A, Roder D. Trends in the terminal care of cancer patients: South Australia, 1981 - 1990. Australian \& New Zealand J Med 1993; 23 ( 3 ): 245 - 51.

Husebo S. Palliative care should be integrated into all aspects of medicine. World Health Forum 1991; 12 ( 4 ): 383.

[ IBGE] Fundação IBGE. Brasil em números. Rio de Janeiro, IBGE, 1998. vol 6.

Illich I. A expropriação da saúde: Nêmesis da Medicina. Rio de Janeiro: Nova Fronteira; 1975.

I.I.E.R. / C.E. ( Instituto de Infectologia Emílio Ribas / Centro de Estudos ) Editorial. Bol Inf Emílio Ribas 1999; 3 ( 15 ): 1.

I.I.E.R. / S.A.M.C.C.D. ( Instituto de Infectologia Emílio Ribas / Serviço Arquivo Médico - Seção de Coleta, Classificação de Dados e Estatísticas ) Boletins de Ocorrências Registradas, Principais Indicadores - Exercício 1984 - 2000.

Jecker NS. Medical Futility and Care of Dying Patients. West J Med 1995; 163: $287-91$.

Jeffers JR, Bognanno MF, Bartlett JC. On the demand versus need for medical services and the concept of "shortage". Am J Public Health 1971; 61: 46 - 63.

Jolly D, Gerbaud I. The hospital of tomorrow. Geneva: WHO / SHS / CC ; 1992.

Johnson AM, Shergold C, Hawkins A, Miller R, Adler MW. Patterns of hospital care for patients with HIV-infection and AIDS. J Epidemiol Community Health $1993 ; 47: 232-7$.

Kahn JO and Walker BD. Acute Human Immunodeficiency Virus Type 1 Infection. N Engl J Med 1998; 339: 33 - 9.

Kai I, Ohi G, Yano E, Kobayashi Y, Miyama T, Niino N, Naka K. Communication between patients and physicians about terminal care: a survey in Japan. Soc Sci Med 1993; $36: 1151-9$.

Kerridge RK, Glasziou PP, Hillman KM. The use of "Quality-Adjusted Life Years" ( $\left.{ }^{*} \mathrm{QALYS}\right)$ to evaluate treatment in intensive care. Anaesth Intens Care 1995; 23: $322-31$.

Kimura R. The right to be informed: an aspect of dignity. World Health Forum $1991 ; 12(4): 391-2$.

Kinoshita RT. Uma experiência pioneira: a reforma psiquiátrica italiana. In: Marsiglia R, Dallari DA, Costa JF, Moura Netto FDM, Kinoshita RT e Lancetti A. Saúde Mental e Cidadania. São Paulo: Mandacaru, 1990. p. 67 - 83. 
Kisil M. Saúde: administração em organizações cambiantes. Rev Paul Hosp. 1988; $36(7 / 9): 123-8$.

Klafke TE. O médico lidando com a morte: aspectos da relação médico-paciente terminal em cancerologia. In: Cassorla RMS, coordenador. Da morte: estudos brasileiros. Campinas, SP: Papirus, 1991. p. 25 - 50.

Kovács MJ. Pensando a morte e a formação de profissionais de saúde. In: Cassorla RMS, coordenador. Da morte: estudos brasileiros. Campinas, SP: Papirus, 1991.

Kovács MJ, coordenadora. Morte e desenvolvimento hunano. São Paulo: Casa do Psicólogo; 1992.

Kovács MJ, Andrade Filho ACC, Sgorlon ACL. Avaliação da qualidade de vida em pacientes oncológicos em estado avançado da doença. In: Carvalho MMMJ, organizadora. Psico-Oncologia no Brasil: resgatando o viver. São Paulo: Summus, 1998. p. $159-85$.

Kübler-Ross E. Sobre a morte e o morrer. São Paulo: Martins Fontes; $1998.8^{\circ} \mathrm{ed}$.

Lepargneur H. O doente, a doença e a morte: implicações sócio-culturais da enfermidade. Campinas ( SP ): Papirus; 1987.

Lessa C. Trabalhando com a morte. Sâo Paulo: Scarpitta; 1995.

Levi J; Kates J. HIV: challenging the health care delivery system. Am J Public Health $2000 ; 90(7): 1033-6$.

Lima L. Colômbia: status of cancer pain and palliative care. J Pain \& Symptom Manage 1993; $8(6): 404-6$.

Lo B, Snyder L, Sox HC. Care at the End of Life: Guiding Practice Where There Are No Easy Answers. Ann Intern Med 1999, 130: 772 - 4.

Lonberger EA, Russell CL, Burton SM. The effects of palliative care on patient charges. J Nurs Adm 1997; 27 ( 11 ): 23 - 6.

Louzã JR, Louzã Neto, MR. O hospital e a morte. Rev Paul Hosp 1982; 30 ( 7/8 ): $172-7$.

Lubitz JD and Riley GF. Trends in Medicare payments in the last year of life. $\mathbf{N}$ Engl J Med 1993; 328: 1092 - 6.

Luczak J, Hunter GP. Hospice care in eastern Europe. Lancet 2000; 356: s 23. 
Lunt B. Terminal cancer care services: recent changes in regional inequalities in Great Britain. Soc Sci Med 1985; $20: 753-9$.

Lynn J. Caring at the end of our lives. N Engl J Med 1996; 335: 201 - 2.

MacCormack C. Hospice and the Holistic Alternative. (Editorial) Soc Sci Med 1994; 38 : vii - ix.

MacDonald N. Palliative care - an essential component of cancer control. CMAJ $1998 ; 158$ ( 13 ): $1709-16$.

Mann JJ. We are all Berliners: notes from the Ninth International Conference on AIDS. Am J Public Health 1993; 83: 1378 - 9.

Marín JR, Llorenz RZ. Estrés, Enfermedad Y Hospitalización. Granada: Escuela Andaluza de Salud Publica; 1997.

Marques AR e Masur $H$. Manifestações Clínicas. In: Veronesi R, Focaccia $R$ e Lomar AV, editores. HIV/AIDS: etiologia, patogenia e patologia clínica: tratamento e prevenção. São Paulo: Atheneu, 1999. p. 123 - 8.

Marshall JC. Charting the course of critical illness: Prognostication and outcome description in the intensive care unit. Crit Care Med 1999; 27 ( 4 ): 676 - 7.

Martin LM. A Ética Médica diante do paciente terminal. Aparecida ( SP ): Santuário; 1993.

Martins JS, organizador. A morte e os mortos na sociedade brasileira. São Paulo: Hucitec, 1983.

McCormick TR, Conley BJ. Patients' perspectives on dying and on the care of dying patients. West J Med 1995; 163: $236-243$.

McCue JD. The Naturalness of Dying JAMA 1995; 273: 1039 - 43 .

McKeown T. The role of Medicine: dream, mirage or nemesis ? London: Nuffield Provincial Hospitals Trust; 1976.

Medina P e Fernandes F. Padrões de mortalidade em assistência domiciliar. Revista Brasileira de Home Care Out $1999: 4$.

Meier DE, Morrison S, Cassel CK. Improving Palliative Care. Ann Intern Med 1997, 127: $225-30$.

Melin A, Hakkansson S, Bygren LO. The cost-effectiveness of rehabilitation in the home: a study of Swedish elderly. Am J Public Health 1993; 83: 356 - 62 . 
Mendes Gonçalves RB. Práticas de saúde: processos de trabalho e necessidades. São Paulo: CEFOR; 1992. ( Cademos CEFOR, Textos 1 ).

Merriman A. Living while dying. Contact 1991; 122: 14. Geneva: Christian Medical Commission / World Council of Churches, 1991.

Michaels SH, Clark R, Kissinger P. Declining morbidity and mortality among patients with advanced human immunodeficiency virus infection. $\quad \mathbf{N}$ Engl J Med 1998; 339: $405-6$.

Mills M, Davies HTO, Macrae WA. Care of dying patients in hospital. BMJ 1994; 309: $583-6$.

Minayo MCS. O desafio do conhecimento: pesquisa qualitativa em saúde. São Paulo: Hucitec / Rio de Janeiro: ABRASCO; $1994 . \quad 3^{\circ} \mathrm{ed}$.

Minayo MCS \& Sanches O. Quantitativo - Qualitativo: oposição ou complementaridade ? Cad Saúde Públ 1993; $9: 239$ - 62 .

Mocroft A, Barry S, Sabin CA, Lepri AC, Kinloch S, Drinkwater A et al. The changing pattern of admissions to a London hospital of patients with HIV: 19881997. AIDS 1999; 13: $1255-61$.

Moinpour CM, Polissar L. Factors Affecting Place of Death of Hospice and NonHospice Cancer Patients. Am J Public Health 1989; 79: 1549 - 51.

Monteiro MFG. Transição demográfica e seus efeitos sobre a saúde da população. In: Barata RB, Barreto ML, Almeida $F^{\circ} \mathrm{N}$, Veras RP. Eqüidade e Saúde: contribuições da Epidemiologia. Rio de Janeiro: FIOCRUZ / ABRASCO; 1997.

Moulias R, Mémin Y. Propositions pour la gérontologie hospitalière. Revue Gériatr 1988; 13: $121-7$.

[ MS ] Ministério da Saúde. AIDS : Assistência médica. Brasília: Ministério da Saúde; 1988.

[ MS ] Ministério da Saúde / Coordenação Nacional de DST e Aids. A Resposta Brasileira ao HIV/Aids: Experiências Exemplares. Brasília: Ministério da Saúde; 1999 a.

[ MS ] Ministério da Saúde / Coordenação Nacional de DST e Aids. Assistência Domiciliar Terapêutica ( ADT ). Brasília: Ministério da Saúde; 1999 b.

[ MS ] Ministério da Saúde / Coordenação Nacional de DST e Aids. Infecçāo pelo HIV em adultos e adolescentes: recomendações para terapia anti-retroviral. Brasília: Ministério da Saúde, 1999 c. 
[ MS ] Ministério da Saúde. Doenças infecciosas e parasitárias - guia de bolso. Elaborado por Penna GO, Teixeira MG e Pereira SM. Brasília: Ministério da Saúde - Fundação Nacional da Saúde, 1999 d.

[ MS ] Ministério da Saúde. AIDS - Bol Epidemiol - 1999/2000; 13 ( 1 ): 47.

Nadler JP. Tratamento Anti-Retroviral: Indicações Clínicas. In: Veronesi R, Focaccia R e Lomar AV, editores. HIV/AIDS: etiologia, patogenia e patologia clínica: tratamento e prevenção. São Paulo: Atheneu, 1999. p. $337-44$.

Naierman N. Debunking the Myths of Hospice. Choices 1998, 7 ( 3 ): 1, 4 - 5.

Nelson JE. Saving Lives and Saving Deaths. Ann Intern Med 1999, 130: 776 - 7.

Nemes MIB. Prática programática em saúde. In: Schraiber LB, Nemes MIB, Mendes-Gonçalves ( org ). Saúde do adulto: programas e ações na unidade básica. São Paulo: Hucitec; 1996. p. 48 - 65.

Nemes MIB. Avaliação da aderência ao tratamento por anti-retrovirais em usuários de ambulatórios do sistema público de assistência à aids no Estado de São Paulo. Prática Hospitalar 1999, Ano I ( 6 ): 15 - 7.

New B. The rationing agenda in the NHS. BMJ 1996; $312(7046)$ : $1593-601$.

N.H.O. - National Hospice Organization. The 1998/99 Guide to the Nation's Hospices. Arlington, WA: N.H.O., 1999.

Nogueira RP. Perspectivas da qualidade em saúde. Rio de Janeiro: Qualitymark; 1994.

Nogueira RP Metáforas da qualidade. Saúde Debate 1995; 47: 36 - 40.

Novack DH, Suchman AL, Clark W, Epstein RM, Najberg E, Kaplan C. Calibrating the Physician: Personal Awareness and Effective Patient Care. JAMA 1997; 278: $502-9$.

Oliveira ACP, Annes M e Casseb J. Manifestações Neurológicas. In: Veronesi R, Focaccia R e Lomar AV, editores. HIV/AIDS: etiologia, patogenia e patologia clínica: tratamento e prevenção. São Paulo: Atheneu, $1999 . \quad$ p. 211 - 35.

Oliveira CG. Introdução à critica das noções empregadas em pesquisa sobre "Satisfação do Usuário". Saúde Debate 1991; 30: 32 - 4.

O'Neill JF and Alexander CS. Palliative Medicine and Hiv/Aids. Primary Care $1997 ; 24$ ( 3 ) : $607-15$. 
Onyemelukwe E, Delfs J. Long-term Care. In: Calkins D, Fernandopulle RJ, Marino BS. Health care policy. Cambridge ( MA ): Blackwell Science; 1995. p. $376-99$

Osterweis $M$ and Champagne DS. The US Hospice Movement: issues in development. Am J Public Health 1979; $69: 492$ - 6.

Palella Jr. FJ, Delaney KM, Moorman AC, Loveless MO, Fuhrer J et al. Declining morbidity and mortality among patients with advanced human immunodeficiency virus infection. N Engl J Med 1998; 338: 853 - 60.

Pallesen AE. Care for the Dying in Denmark. Danish Medical Bulletin 1992; 39 ( 3 ): $265-8$.

Pan Chacon J, Kobata CM, Liberman SPC. A "mentira piedosa" para o canceroso. Rev Ass Med Brasil 1995; 41 ( 4 ): 274 - 6.

Paradis LF. Hospice handbook: a guide for managers and planners. Rockville: Aspen; 1985. The development of hospice in America: a social movement organizes. p. 3 - 24.

Paradis LF, Cummings, SB. The evolution of hospice in America toward organizational homogeneity. J Health Soc Behav 1986; 27: 370 - 86.

Parker R, Camargo Jr. KR. Pobreza e HIV/Aids: Aspectos antropológicos e sociológicos. In: Coordenação Nacional de Doenças Sexualmente Transmissíveis e Aids. Sobre a epidemia de aids no Brasil: distintas abordagens. Brasília: Ministério da Saúde; 1999.

Penchas S. Rationing, rights and responsibilities in health care. Hosp Manage Int $1996 ; 58-61$.

Pessini L. Eutanásia e América Latina: questões ético-teológicas. Aparecida (SP): Santuário; 1990.

Pessini L. Distanásia: até quando investir sem agredir ? Bioética 1996; 4: 31 - 43.

Pessini L, Barchifontaine CP. Problemas atuais de Bioética. São Paulo: Loyola; 2000.

Poggi C, Profizi N, Djediouane A, Chollet L, Hittinger G, Lafeuillade. Long-term evaluation of triple nucleoside therapy administered from primary HIV-1 infection. . AIDS 1999; 13: $1213-20$.

Poisson-Salomon AS, Mayaud C, Blum Boisgard C. Medical and social factors in the orientation of patients with AIDS after discharge. Rev Epidemiol Santé Publique 1995; 43: 37 - 47. 
Pritchard RS, Fischer ES, Teno JM, Sharp SM, Reding DJ et al. Influence of patient preferences and local health systems characteristics on the place of death. J Am Ger Soc 1998; $46(10): 1242-50$.

[ Pro-AIM ] Programa de Aprimoramento das Informações de Mortalidade no Município de São Paulo. Dados referentes ao $4^{\circ}$ trimestre/1999. PRO-AIM 2000: 38.

Quill TE and Townsend P. Bad news: Delivery, Dialogue and Dilemmas. Arch Intern Med 1991; 151: 463 - 8.

Rabow MW, Hardie GE, Fair JM, McPhee SJ. End-of-Life Care in 50 Textbooks from Multiple Specialties. JAMA 2000; 283: 771 - 8.

Relman AS. Assessment and Accountability: the third revolution in Medical Care. N Engl J Med 1988; 319: 1220 - 2 .

Rhymes J. Hospice Care in America. JAMA 1990; 264: 369 - 72.

Rico MA. Palliative care in Chile. Eur J Pall Care 1997; 4 ( 4 ): 138 - 9.

Roberts CJ. Epidemiology and the management of health service resources. Int J Epidemiol 1984; 13:271 - 2 .

Robin ED. Matters of Life $\&$ Death: Risks vs. Benefits of Medical Care. New York: W.H. Freeman; 1984. The terminally ill and the aged. p. $111-8$.

Rosemblum LS, Buheler JW, Morgan M, Moien M. Increasing impact of HIV infection on hospitalizations in the United States, 1983 - 1988. J. Acquir Immune Defic Syndr 1992; $5: 497$ - 504 .

Rousseau P. Hospice and Palliative Care. Disease-a-month 1995; 41 ( 12 ): 773 842.

Royce RA, Seña A, Cates W, Cohen MS. Sexual transmission of HIV. N Engl J Med 1998; 336: $1072-8$.

Saltman RB e Figueras J. European Health Care Reform: analysis of current strategies. Copenhagen: WHO; 1998. Confronting resource scarcity. p. $79-112$.

Sancho MG. Morir com Dignidad. Prática Hospitalar 2000; 2 ( 9 ): 55 - 62.

Sanz-Ortiz J e Llamazares Gonzalez A. Home care in a palliative care unit. Med Clin 1993; $101(12): 446-9$. 
São Paulo ( Estado ). Lei 10.349 de 19-07-99. Dispõe sobre as diretrizes orçamentárias para o exercicio de 2000. Diário Oficial do Estado de São Paulo, São Paulo, 20-07-99; Vol 109 ( 135 ): Seção I: 1 - 9.

Saunders $C$ and Baines $M$. Living with Dying: the management of terminal disease. New York: Oxford University Press; 1983.

Saunders C. The Hospice Movement. Contact 1991, 122: 1- 5. Geneva: Christian Medical Commission / World Council of Churches, 1991.

Saunders C. Foreword. In: Doyle D, Hanks GW \& MacDonald N, editores. Oxford textbook of palliative medicine. Oxford: Oxford University Press; 1995. p. v - viii.

Sayd JD. A escola médica e seus implícitos sobre a morte. R Bras Educ Méd $1993 ; 17(3): 14-9$.

Sbanotto A et Burnhill R. Palliative care in Italy: the current situation. Supportive Care in Cancer 1998; $6(5): 426-9$.

Schneiderman LJ, Jecker NS and Jonsen AR. Medical futility: its meaning and ethical implications. Ann Intern Med 1990, 112: 949 - 54.

Schofferman J. Medicine and the Psychology of Treating the Terminally Ill. In: McKusick L. ( editor) What to do about AIDS. Berkeley ( CA ): University of California; 1986. p. $51-60$.

Schraiber LB. O médico e seu trabalho: limites da liberdade. São Paulo: Hucitec; 1993. Liberdade, o pressuposto do trabalho. p. 147 - 77.

Schraiber LB, Mendes Gonçalves RB. Necessidades de saúde e atenção primária. In: Schraiber LB, Nemes MIB e Mendes Gonçalves RB. ( org ) Saúde do Adulto: prgramas e ações na unidade básica. São Paulo: Hucitec; 1996. p. 29 - 47.

Selwin PA. HIV therapy in the real world. AIDS 1996; 10: $1591-3$.

Selwin PA and Arnold R. From Fate to Tragedy: The Changing Meanings of Life, Death and AIDS. Ann Intern Med. 1998; 129: 899 - 902.

Shanley E. The medicalisation of dying - 1. Nursing Times 1982 Aug 11; $1360-2$.

Silva Filho JF. A medicina, a psiquiatria e a doença mental. In: Tundis SA e Costa NR ( org ) Cidadania e loucura. Petrópolis: Vozes / ABRASCO; 1987. p. 75 - 102.

Simioni AMC. O gerenciamento de recursos humanos em saúde como processo social. [ Dissertação de mestrado.] Faculdade de Saúde Pública da Universidade de São Paulo. São Paulo, 1996. 
Singer PA, Martin DK, Kelner M. Quality End-of-Life Care: Patients' perspectives. JAMA $1999 ; 281: 163-8$.

Smith AM. Alternatives in AIDS homecare. AIDS Patient Care 1994; 1: 28 - 32.

Smith MY, Knickman JR, Oppenheimer LM. Connecting the disconnected: adult day care for people with AIDS in New York City. HIth Soc Work. 1992; 17 : $273-81$.

Sochalski J, Aiken LH, Fagin CM. Hospital Restructuring in the United States, Canada, and Western Europe.: an outcomes research agenda. Med Care 1997; 35: OS13- 25 .

Souto L. Além da iatrogênese. Saúde Debate 1992; 35: 33 - 4.

Speer TL. Care and Care Alike. Hosp Hith Networks 1998; 72 ( 19 ): 36 - 9.

Stansell JD, Follansbee SE. Management of late-stage AIDS. In: Sande MA, Volberding PA. The medical management of AIDS. Philadelphia: WB Saunders; 1995. cap. 34.

Steel K, Ribbe M, Ahronheim J, Hedrick H, Selwyn PA, Forman W et al. Incorporating education on palliative care into the long-term care setting. JAGS 1999; $47: 904-7$.

SUPPORT Investigators. A Controlled Trial to Improve Care for Seriously Ill Hospitalized Patients. JAMA 1995; 274: 1591 - 8.

Szasz T. Ideologia e doença mental: ensaios sobre a desumanização psiquiátrica do homem. Rio de Janeiro: Zahar; 1977.

Szwarcwald CL, Bastos FI, Fonseca MGP, Esteves MAP, Andrade CLT. A disseminação da epidemia de aids no Brasil, no período de 1987 - 1996: uma análise espacial. In: Coordenação Nacional de Doenças Sexualmente Transmissíveis e Aids. Sobre a epidemia de aids no Brasil: distintas abordagens. Brasília: Ministério da Saúde; 1999.

Thelot B, Monteil C. L'hospitalisation pour infection par VIH dans les hôpitaux de Paris. Ann Med Intern 1992; 143: 99 - 103.

Thiermann SE. If I should die before I wake: an investigation of nontraditional spiritual approaches to working with the dying. Philadelphia (PA); 1991 [ PhD thesis -Temple University ].

Thorpe G. Enabling more dying people to remain at home. BMJ 1993; 307 (6909): $915-8$. 
Tomlinson T, Brody H. Futility and the Ethics of Resuscitation. JAMA 1990; 264: $1276-80$.

Ventafridda V. At home or in hospital ? World Health Forum 1991; 12 (4): 382 -3.

Veugelers PJ and Schechter MT. The incubation period of HIV infection Cur Opinion Infectious Diseases 1997; $10(1): 7-11$.

Vianna A, Piccelli H. O estudante, o médico, e o professor de medicina perante a morte e o paciente terminal. Rev Ass Med Brasil 1998; 44 ( 1 ): 21 - 7.

von Gunten CF, Ferris FD, Emanuel LL. Ensuring competency in end-of-life care: communication and relational skills. JAMA 2000; 284: 3051 - 7.

Wald FS. The Emergence of Hospice Care in the United States. In: Spiro HM, Curnen MGM, Wandel LP ( editors ). Facing Death. New Haven: Yale University Press; 1996.

Waldman EA. A transição epidemiológica: tendências e diferenciais dos padrões de morbimortalidade em diferentes regiões do mundo. O mundo da Saúde 2000; 24 (1): $10-8$.

Wanzer SH, Federman, DD, Adelstein J, Cassel C, Cassem EH et al. The physician's responsibility toward hopelessly ill patients. N Engl J Med 1989; 320: 844 - 9 .

Webster ME. Communicating with dying patients Nurs Times, 1981; 77: 999 1002.

Weeks JC, Cook EF, O'Day SJ, Peterson LM, Wenger $N$, Reding D et al. Relationship between cancer patients' predictions of prognosis and their treatment preferences. JAMA 1998; 279: 1709 - 14.

Weidle PJ, Holmberg SD, DeCock KM. Changes in HIV and Aids epidemiology from generation antirretroviral therapy. AIDS 1999; 13 suppl A: S 61 - 8.

Weinstein MC, Stason WB. Foundations of cost-effectiveness analysis for health and medical practices. N Engl J Med 1977; 296: $716-21$.

Welch HG, Wennberg DE, Welch WP. The use of Medicare home health care services. N Engl J Med 1996; 335: 324 - 9.

Welch K, Kissinger P, Bessinger R, Dascomb K, Morse A, Glecker E. The clinical profile of end-stage AIDS. AIDS Pat Care STDs 1998; 12 ( 2 ): 125 - 9 .

Welsby PD and Richardson AM. Palliative care aspects of adult acquired immune deficiency syndrome. In: Doyle D, Hanks GW \& MacDonald N, editores. Oxford 
textbook of palliative medicine. Oxford: Oxford University Press; 1995 . p. 737 57.

Wennberg JE. On patient need, equity, supplier-induced demand, and the need to assess the outcome of common medical practices. Med Care 1985; 23: 512 - 20.

Westphal MF, Bógus CM, Faria MM. Grupos focais: experiências precursoras em programas educativos em saúde no Brasil. Bol Oficina Sanit Panam 1996; 120 (6): $472-82$.

[ WHO ] World Health Organization / Joint United Nations Programme on HIV/AIDS. AIDS Epidemic update: December 1999. Geneva: WHO, 1999.

Williams A. Priority setting in public and private health care. J Health Econ 1988; $7: 173-83$.

Williams B, Coyle J, Healy D. The meaning of patient satisfaction: an explanation of high reported levels. Soc Sci Med 1998; 47: $1351-9$.

Williams MK. Billie Belle's Unkind Death. Ann Intern Med 2000, 133: 743 - 4.

Wlody GS. in: Shoemaker WC, Ayres SM, Grenvik A, Holbrock PR. Textbook of Critical Care. Philadelphia: WB Saunders; 1995. $3^{\circ} \mathrm{ed}$. The impact of healthcare and technology trends on critical care practice. p. $1721-7$.

Wood CGA, Whittet S, Bradbeer CS. ABC of palliative care: HIV infection and AIDS. BMJ 1997; 315: 1433 - 6.

Xu K \& Hu S. Home care for the elderly. World Health Forum 1996, 17: 357 - 9.

Yin D, Forman HP, Langlotz CP. Evaluating health services: the importance of patients' preferences and quality of life. Am J Roentgenol 1995; 165: 1323 - 8.

Youngner SJ. in: Shoemaker WC, Ayres SM, Grenvik A, Holbrock PR. Textbook of Critical Care. Philadelphia: WB Saunders; 1995. $3^{\circ}$ ed. Medical Futility. p. $1798-802$.

Zaidhaft S. Morte e formação médica. Rio de Janeiro: Francisco Alves; 1990.

Zucconi SL, Jacobson LP, Schrager LK, Kass NE, Lave Jr, Carson CA et al. Impact of immunosuppression on health care use in the Multicenter AIDS Cohort Study (MACS). J Acquir Immune Defic Syndr 1994; 7: 607 - 16.

Zuger A, Sharp VL. "HIV Specialists": the time has come. JAMA 1997; 278: 11312. 


\section{Anexo A}

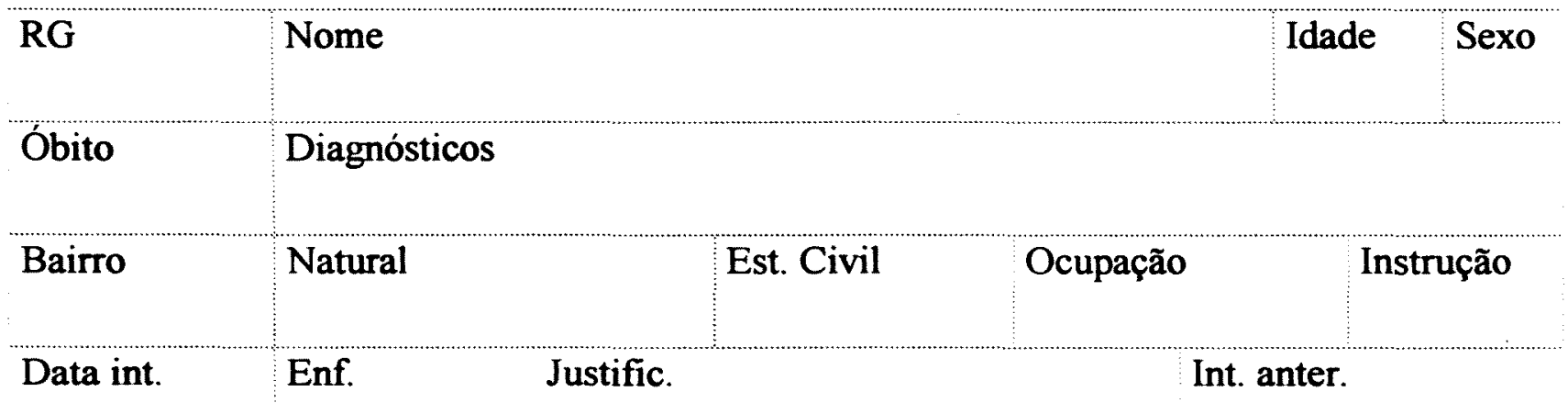

\section{Antecedentes}

Evolução, sintomas

Prescrição

Profissionais

Observações 


\section{Anexo B}

\section{Projeto: "Alternativas de assistência hospitalar"}

Cargo/Função

Tempo:

Local /Turno: Tempo I.I.E.R.

Idade:

Sexo:

Responder sucintamente, usando palavras como: nenhuma, pouca, muita, rara, freqüente, etc, nos espaços entre parênteses e, com suas próprias palavras, nos espaços pontilhados.

1- Experiência com atendimento hospitalar : internação convencional ( hospital-dia atendimento domiciliar ambulatório

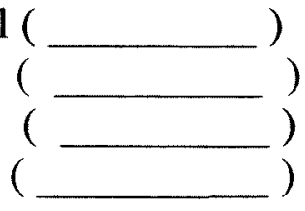

2- Vantagens de: internação convencional atend. domiciliar hospital-dia

3 - Desvantagens : internação convencional

atend. domiciliar hospital-dia

4 - Dê uma nota para a qualidade do atendimento dispensado aos pacientes de AIDS tratados neste hospital, em regime de internação, hospital - dia e/ou atendimento domiciliar, de 1 ( nota pior ) a 5 ( nota melhor ):

5 - Sua experiência no atendimento a doentes terminais: freqüência (

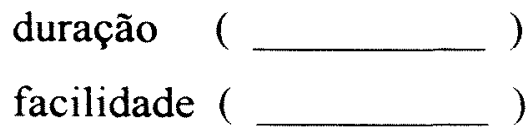

6 - Dê uma nota, de 1 ( nota pior) a 5 ( nota melhor) para esse atendimento ( a doentes terminais ):

7 - Sugestões, observações: 


\section{Anexo $C$}

Especialidade, funçono:

Sero:

Idade:

Tempo de formado:

Tempo de I.I.E.R.:

Local de trabalho:

Matores dificuldades, para o atendimento ao doente terminal:

Temas sugeridos, para estudio, em ordem de preferèncto:

Modalidaute de aprendizagen, em ordem de preferencia: ( ) palestras com especialistas ( ) estudo em grupo. vivencia grupal () curso formal

( ) leitura de textos

( ) outros:

Hordrio dispontvel:

Singestoes: 